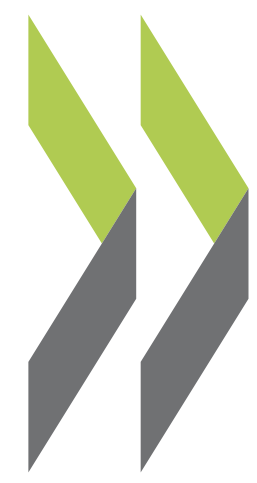

OECD Economics Department Working Papers No. 1077

Romain Bouis,

Deleveraging: Challenges, Progress and Policies

Ane Kathrine
Christensen,

Boris Cournède 


\section{Unclassified}

ECO/WKP(2013)69

Organisation de Coopération et de Développement Économiques

Organisation for Economic Co-operation and Development

05-Aug-2013

ECONOMICS DEPARTMENT

English - Or. English

DELEVERAGING: CHALLENGES, PROGRESS AND POLICIES

ECONOMICS DEPARTMENT WORKING PAPERS No. 1077

By Romain Bouis, Ane Kathrine Christensen and Boris Cournède

All Economics Department Working Papers are available through the OECD's Internet website at http://www.oecd.org/Workingpapers

JT03343347

Complete document available on OLIS in its original format

This document and any map included herein are without prejudice to the status of or sovereignty over any territory, to the delimitation of international frontiers and boundaries and to the name of any territory, city or area. 


\section{ABSTRACT/RÉSUMÉ}

\section{Deleveraging: challenges, progress and policies}

In the run-up to the financial crisis, indebtedness of households and non-financial businesses rose to historically high levels in many OECD countries; gross debt of financial companies rose dramatically relative to GDP. Much of the debt accumulation appears to have been based on excessive risk-taking and exceptional macro-economic conditions and therefore not sustainable. Since the start of the crisis, non-financial private sector debt has receded substantially in the United States and the United Kingdom. Other OECD countries have not experienced significant debt reduction but already achieved some adjustment in terms of private saving and investment (with the seeming contradiction between these two observations explained by the private sector accumulating gross financial assets at a faster pace). Some macro-economic risks related to future household deleveraging nevertheless remain in a few OECD countries where indebtedness has risen in recent years. In the financial sector, possible future deleveraging will be more damaging to growth if it involves reducing assets rather than retaining (or raising) equity. To speed up the deleveraging process and minimising its impact on prosperity, bad loans should be recognised swiftly, losses taken, insolvent banks wound down orderly and capital shortfalls plugged at still solvent banks.

JEL classification codes: E44; E51; E21; G21; G28.

Keywords: Deleveraging; household debt; non-financial corporation debt; financial sector debt; housing prices; household saving, residential investment; non-performing loans; financial regulation.

$$
* * * * * *
$$

\section{Désendettement : enjeux, progrès et politiques économiques}

Dans la période qui a précédé la crise, l'endettement des ménages et des entreprises non financières a augmenté jusqu'à des niveaux historiquement élevés dans de nombreux pays de l'OCDE. La dette brute des entreprises financières s'est accrue de manière spectaculaire par rapport au PIB. Une grande part de cet endettement, qui semble avoir été la contrepartie d'une prise de risque excessive dans un environnement macro-économique exceptionnellement favorable, ne paraît pas soutenable. Depuis le commencement de la crise, la dette du secteur privé non financier a reculé aux États-Unis et au Royaume-Uni. Aucune réduction significative de l'endettement n'a été observée dans plusieurs autres pays de l'OCDE qui ont toutefois effectué une part d'ajustement en termes d'épargne privée et d'investissement immobilier. La contradiction apparente entre ces deux observations s'explique dans ces pays par une accélération de l'acquisition d'actifs financiers bruts par le secteur privé. La possibilité d'un désendettement des ménages continue néanmoins de faire peser un risque macroéconomique sur certains pays de l'OCDE qui ont connu une augmentation de l'endettement au cours des dernières années. S'agissant du secteur financier, une éventuelle baisse du ratio d'endettement sera plus dommageable à la croissance si elle se produit au moyen de réductions d'actifs plutôt que par l'accumulation de capital. Afin d'accélérer le processus de réduction de l'effet de levier et de réduire ses conséquences défavorables pour la prospérité économique, il convient d'identifier rapidement les prêts improductifs, de comptabiliser les pertes qui leur sont associées, de liquider les banques non solvables et de combler les besoins en capital des banques qui demeurent solvables.

Codes JEL : E44; E51; E21; G21; G28.

Mots clé : désendettement, réduction de l'effet de levier, dette des entreprises non financières, dette du secteur des entreprises financières, prix de l'immobilier, prix du logement, épargne des ménages, investissement immobilier résidentiel, prêts improductifs, crédits en souffrance. 


\section{TABLE OF CONTENTS}

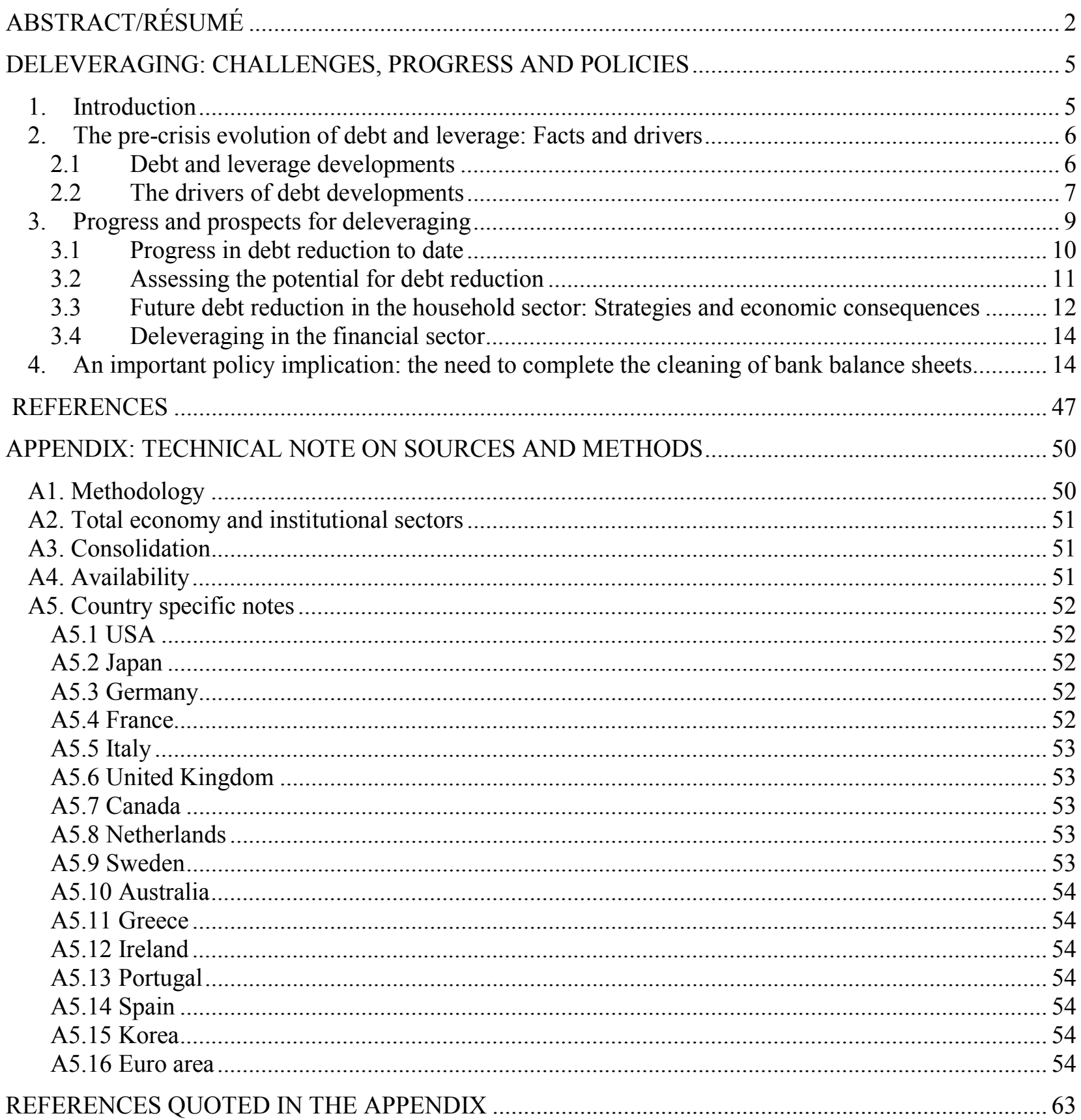

\section{Boxes}

1. Dealing with bank deleveraging: Sweden vs. Japan and Chile vs. Mexico...................................... 15 


\section{Tables}

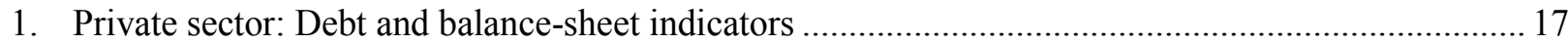

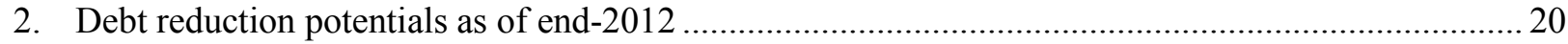

3. Changes in household debt ratios, saving rates, housing investment and housing prices from 1997 to 2007 and from 2007 to 2012 .

\section{Figures}

1. Domestic debt-to-GDP ratio of the non-financial economy …........................................................ 22

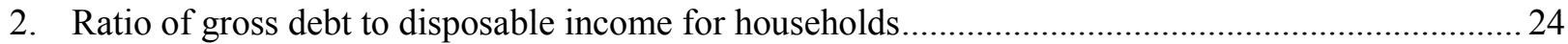

3. Ratio of net financial wealth to gross disposable income of households ......................................... 26

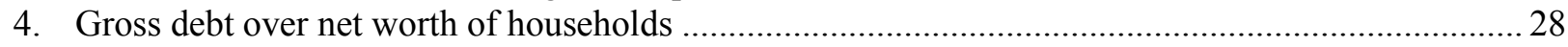

5. Ratio of debt to gross operating surplus for non-financial corporations …....................................... 30

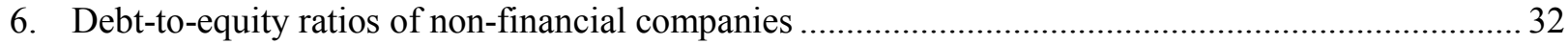

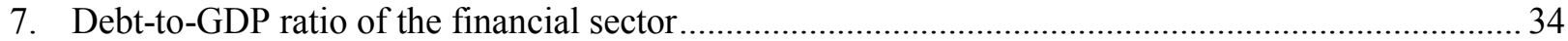

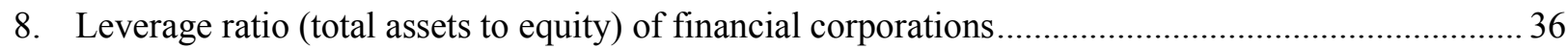

9. House price increases and the rise in household debt ratios are positively related ............................. 38

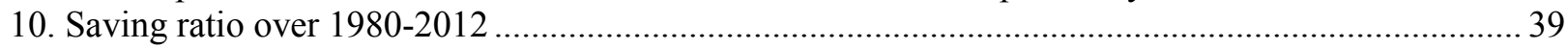

11. Debt reduction and changes in household saving and residential investment ratios ......................... 41

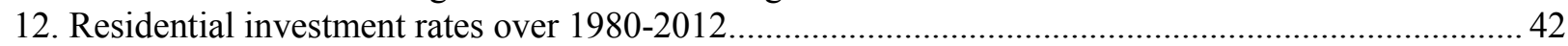

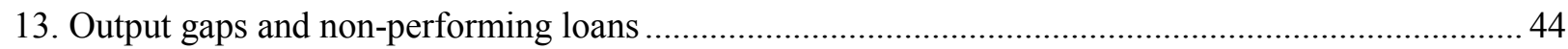

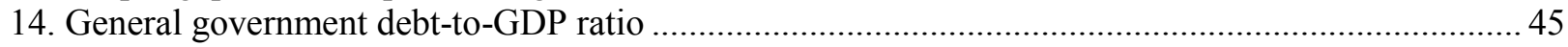


ECO/WKP(2013)69

\title{
DELEVERAGING: CHALLENGES, PROGRESS AND POLICIES
}

\author{
By Romain Bouis, Ane Kathrine Christensen and Boris Cournède ${ }^{1}$
}

1.

Introduction

1. In the run-up to the 2008-9 crisis, households and non-financial businesses in several countries increased their indebtedness to exceptionally high levels and financial institutions expanded their balance sheets massively. ${ }^{2}$ A large part of the debt build-up is likely to have been driven by increased credit availability, related to financial market reforms and innovations in the context of inadequate regulation, atypically low global interest rates and excessive risk-taking by financial institutions that benefited from an implicit state guarantee; hence, much of the increase in debt may be regarded as "excessive". Recent empirical evidence indicates that, when private sector debt levels, especially for households, rise above trend, the likelihood of recession increases (Sutherland et al., 2012).

2. Deleveraging in the private sector has been underway in a few countries, notably the United States and the United Kingdom, with associated headwinds for economic growth; it has not started in some high-debt countries, including some euro area countries, and could have a negative impact on growth in these countries in the future. According to the latest data (end of 2012), the debt reduction potential in the non-financial private sector is particularly high in inter alia France, Italy and the United Kingdom and relatively mild in the United States; no deleveraging is needed in Japan and Germany. For financial corporations, significant reduction could take place in several European countries to bring their debt-toGDP ratios back to pre-boom levels. Large and ill-understood differences in debt levels across countries, however, suggest some caution in interpreting such estimates of likely debt reduction.

3. The possible reduction of debt in the private sector raises the issue of the macroeconomic costs of the adjustment and how economic policy can best respond. Data indicate that in several economies a significant part of the adjustment in terms of higher saving and lower housing investment has already been made. This observation holds even in countries where deleveraging has not taken place yet: in these countries, continued rising indebtedness has been compatible with higher saving and lower investment because the private sector has stepped up its purchases of financial assets. Saving rates tend to increase around deleveraging episodes in particular for precautionary motives due to deteriorated economic conditions rather than out of attempts to deleverage per se. Likewise, housing investment often decreases

1. The authors are members of the OECD Economics Department. They are grateful to Christophe André, Sveinbjörn Blöndal, Jørgen Elmeskov, Andrés Fuentes and Jean-Luc Schneider for their comments. The responsibility for any errors lies solely with the authors. The authors would like to thank Isabelle Fakih and Maartje Michelson for excellent editorial support. The views expressed in this paper are the authors' and should not be attributed to the OECD or its member countries. Corresponding author: romain.bouis@oecd.org.

2. In this paper, the terms "deleveraging" and "reduced indebtedness" are used interchangeably with falling debt-to-income ratios, in line with what has become common usage. 
before debt ratios decline and has already significantly adjusted downwards in a number of countries over the past years.

4. To speed up the deleveraging process, supervisors need to ensure that bad loans be recognised swiftly, losses be taken, insolvent banks be wound down orderly and capital shortfalls be addressed even if this requires injections of public funds. In many countries, recorded bad loans appear to be low in view of the weak cyclical conditions, perhaps reflecting a tendency to ever-green non-performing loans in a low interest rate environment.

5. This paper addresses these issues under four main headings. It first briefly reviews the evolution of debt prior to the 2008-09 crisis in the United States, Japan, Germany, France, Italy, the United Kingdom, Canada, Australia, Belgium, Greece, Ireland, Korea, the Netherlands, Portugal, Spain, Sweden and Switzerland before discussing driving forces behind those developments (Section 2). It then reviews progress in reducing debt ratios since the onset of the crisis and assesses deleveraging potential at the time of writing in the private sectors, and the likely growth impact of the adjustment mechanisms required to unwind past developments (Section 3). It then turns to the policy implications, focusing on how policy can speed up and cushion the process of deleveraging (Section 4). For an empirical investigation of the link between debt and stability, see for instance Sutherland et al. (2012).

\section{The pre-crisis evolution of debt and leverage: Facts and drivers}

\subsection{Debt and leverage developments}

6. The ratio of gross debt to GDP in the non-financial sectors evolved in contrasting ways across countries in the run-up to the financial crisis (Figure 1):

- The pre-existing positive trend in the ratio steepened in a few countries, including Spain, the United Kingdom, United States, and the debt ratio continued to grow at a rapid pace in Italy, France and the Netherlands. In these countries increased indebtedness in both the non-financial private sector and the government sector contributed to this development.

- The previous trend came to a halt in a few countries, including Canada and Sweden. In these countries falling gross debt ratios in the government sector coincided with falling or broadly stable debt ratios in the non-financial private sector.

- In Japan and Germany, the gross debt ratio in the non-financial sectors fell in the 2000-07 period, with reduced debt ratios in the non-financial private sector more than offsetting higher indebtedness in the government sector.

7. Within the non-financial private sector, there was a tendency for debt to increase relative to GDP and sector-specific income in the household and, to a lesser extent, non-financial business sector in several countries:

- With the notable exceptions of Japan and Germany, household gross indebtedness rose in the run-up to the crisis in all covered countries. Gross household debt relative to disposable income rose particularly strongly in the United Kingdom and the Netherlands, followed by Sweden and the United States (Table 1 and Figure 2). Even so, thanks to strong increases in equity prices after the bursting of the dotcom bubble in the early 2000s, households' net financial wealth rose strongly in many countries (Figure 3) though not everywhere with Italy, Belgium, Greece and Ireland being exceptions. As households' net worth was boosted by strong increases in residential property prices, the leverage ratio, i.e. gross debt divided by net worth, was broadly stable or fell 
in many countries, rising significantly however in the Netherlands, Korea and Portugal and, to a lesser extent, the United Kingdom, Italy and Australia (Figure 4). ${ }^{3}$

- Non-financial corporate debt developments from 2000 to 2007 varied across countries. Relative to operating surplus, debt increased notably strongly in the United Kingdom, Ireland, Italy, Portugal, Spain and Sweden (Table 1 and Figure 5). This development reflects in part increased lending to commercial real estate business. On the other hand, it was broadly stable or fell in the other countries, with notably steep reductions in Japan and the Netherlands. Debt-to-equity ratios of non-financial corporations were stable or decreased in most countries in the seven years prior to the crisis (Table 2 and Figure 6).

These developments implied continued large cross-country differences in the level of indebtedness of the private non-financial sectors. For households, it ranged from less than $100 \%$ of disposable income in France, Italy and Belgium to $200 \%$ or more in the Netherlands and Switzerland, reflecting different institutional environments; ${ }^{4}$ for non-financial corporations, the ratio of gross debt to gross operating surplus varied from less than four in Germany, Canada and Belgium to more than six in the United States, Japan, the United Kingdom and Sweden.

8. Gross debt of the financial sector rose much more strongly relative to GDP than for the nonfinancial sectors (Table 1 and Figure 7). ${ }^{5}$ Indeed, in the 2000-07 period, the debt-to-GDP ratio rose by around 500 and 250 percentage points in Ireland and the United Kingdom, respectively, and by around 100 percentage points or more in Belgium, France, the Netherlands and Switzerland. Even so, with the notable exceptions of the United Kingdom and Italy, the leverage of the aggregate financial sector - measured by the ratio of assets to equity valued at market prices - rose only modestly or even decreased in this period (Figure 8), as the equity base was boosted by elevated asset prices and large retained earnings on the back of record profits in the industry. This masks disparate developments across sub-sectors, with leverage increasing markedly among investment banks, large broker-dealers and government-sponsored agencies and falling elsewhere (Sutherland and Hoeller, 2012). For example, based on banks' financial statements, the leverage of global systemically important financial institutions (GSIFIs) rose from 25 to 35 in the 2000-07 period (Slovik, 2012).

\subsection{The drivers of debt developments}

\subsubsection{Households}

9. The evolution of gross debt developments in the household sector in the run-up to the crisis was driven by many factors affecting households' optimum consumption and investment strategies in the face of rising asset prices and perceived falling macroeconomic risks (see e.g. Cecchetti et al., 2011 or Finocchiaro et al., 2011):

3. Net worth and the leverage ratio can however be misleading indicators of debt sustainability as asset values are more volatile than liabilities. For instance, as was observed during the recent economic crisis in the United States, households with net housing wealth can relatively quickly find themselves with negative equity following a house price crash.

4. Including differences in pension systems, housing finance markets, legal rights of creditors, bankruptcy laws and judicial efficiency.

5. Data for debt and equity of financial corporations are based on national accounts principles, including the valuation at market prices. Government-owned financial corporations, such as Fanny Mae and Freddie Mac in the United States, are included in the financial sector. 
- Very low real interest rates prior to the crisis, driven in part by a global saving glut and the procyclical behaviour of financial institutions' leverage, contributed to excessive debt accumulation. This pattern has been exacerbated by the asymmetric reaction of monetary policy to asset price booms and busts, as suggested, for instance, by the positive correlation between house loans and the deviations of short-term interest rates from Taylor rules (Ahrend et al., 2008). With tax breaks for interest payments remaining in place in many countries, post-tax real interest rates were particularly low.

- Financial innovation has increased the share of households able to borrow and the amount of debt held by those who already had access to credit, thanks to a relaxation of quantity constraints (with more accommodative loan-to-value ratios and longer amortization periods). Debt-service ratios were nevertheless relatively stable or even decreased, despite higher amounts of borrowing, because of lower interest rates.

- Rapid increases in property prices in the pre-crisis period may have generated expectations of continued future increases and hence boosted demand for credit to acquire property and obtain the associated capital gains, triggering the typical feedback loop driving credit-fuelled asset-price booms.

- Expansion of the asset side of households' balance sheets prompted adjustment on the liability side to maintain a desired ratio of net wealth to income. Thus, rapid growth in property prices increased demand for housing equity withdrawal and the build-up of private pension assets in some countries may have had similar effects.

- To the extent that households behaved in a Ricardian way and pierced the corporate veil, improvements in the balance sheets of the government and corporate sectors may in some countries have encouraged households to accumulate debt. ${ }^{6}$

- The apparent reduction in macroeconomic risks during the Great Moderation period may have reduced a precautionary restraint on households to enter into debt and associate repayment commitments.

10. Financial reform and innovation resulted in increased credit supply to meet the added demand and spurred demand by offering more flexible loan conditions. For instance, in the United States, mortgage securitization appears to have lowered the spread between mortgage and risk-free rates while innovations facilitating taking a loan against housing equity enabled households to borrow more in a context of rising house prices (Dynan and Kohn, 2007). Relaxed rules on segmentation in the financial sector, such as the repeal of the Glass-Steagall Act in the United States, spurred the entry of new large institutions into the mortgage market. Some of these were arguably ready to take higher risk on the back of an implicit state guarantee and this accelerated innovation in the market, such as complex and opaque securitisation chains, which contributed to increased offer of sub-prime mortgages. At the same time, lending institutions in many countries took advantage of relaxation of government regulations on lending terms by e.g. increasing loan-to-value ratios, relaxing income requirements and extending amortisation period for mortgage loans.

11. Policies and institutions have not been the sole drivers of the rise in indebtedness. Many countries have also experienced a positive feedback loop between house prices and credit which may have been sparked by policy changes but then fed on itself. Dynan and Kohn (2007) document a significant effect of

6. Empirical studies indicate that households partially incorporate government indebtedness in their spending decisions, see e.g. Roehn (2010). 
house prices on households' debt-income ratios in the United States while OECD data show a clear cross-country relationship between house price increases and the development of household debt over the period 2000-2007 (Figure 9).

\subsubsection{Non-financial businesses}

12. In the non-financial corporate sector, the capital structure tends to be biased towards debt in most countries, given that interest payments can be deducted for tax purposes, and equity is used mainly to reduce bankruptcy risks and agency costs. That said, in recent years, cuts in corporate tax rates have reduced the tax bias in favour of debt. ${ }^{7}$ On its own, this should have reduced leverage ratios in the noncorporate sector. On the other hand, debt in the commercial real estate sector may have been boosted by financial innovations and rising commercial property prices in the same way as for households. Financial innovation is also likely to have raised the scope for leveraged buy-outs which rose in the run-up to the financial crisis.

\subsubsection{Financial institutions}

13. The increase in leverage that took place in systemically important financial institutions (SIFIs) before the crisis can be linked, at least in part, to financial innovations and regulatory arbitrage inherent in the risk-weighted capital requirement system (Blundell-Wignall and Atkinson, 2011; Slovik, 2012). For example, the securitisation of mortgage debt allowed banks to increase their leverage as mortgage-backed securities had lower risk weight than the underlying mortgages. Also, the development of the credit default swap market made it easier for the capital cover in the banking system to be reduced as the derivative exposure of the counter-party bank had a lower risk weight than the loan being insured (and the capital cover could be reduced to zero if the counterparty was not covered by the risk-weighted system). Supervision of the financial sector failed to block the increase in leverage, partly because it was often fragmented across institutions and did not cover some unregulated activities. Also, the market had limited incentives to check the increase in leverage as the SIFIs were seen to enjoy an implicit government guarantee as they were too big to fail.

\subsubsection{Conclusion}

14. Much of the debt build-up and increased leverage in the run-up to the crisis appears to have been driven by low global interest rates and financial liberalisation and innovation. The latter allowed increased scope for regulatory arbitrage and excessive risk-taking by financial institutions, especially those regarded as being too big to fail, and amplified feed-back loops between higher household debt and higher property prices. Nonetheless, the varying trends across countries suggest that country-specific factors also played a significant role. Even so, in most countries, a large part of the increase in indebtedness and leverage in the run-up to the crisis can probably be regarded as being "excessive".

\section{Progress and prospects for deleveraging}

15. Historical experience suggests that deleveraging takes time. Sutherland et al. (2012) document that large debt reduction episodes last $6 \frac{1}{2}$ years for the household and non-financial sectors on average across OECD countries. Similarly, Igan et al. (2012) report a median duration of household deleveraging episodes of seven years, with a reduction in the debt-to-income ratio of 23 percentage points on the basis of a sample of 11 household deleveraging episodes in OECD countries. MGI (2010) reports similar figures for the total economy using 16 historical episodes of deleveraging. Tang and Upper (2010) also document

7. In Germany, for instance, a major corporate and income tax reform implemented in 2001 increased the tax incentives in favour of profit retention (Ruscher and Wolff, 2012). 
a significant decline in indebtedness for a sample of 17 banking crises preceded by credit booms. On average, the ratio of credit to the private sector to GDP decreased by 38 percentage points, as a consequence of debt repayments, default on debt, inflation and economic growth. Finally, Ruscher and Wolff (2012) report an average duration of deleveraging for non-financial corporations of about eight years, based on a sample of 35 cross-country episodes of balance sheet adjustments.

16. Against the background of this evidence, this section reviews progress in debt reduction since the onset of the crisis, identifies debt reduction potentials for different sectors, and explores how they may be achieved and the implications this could have for economic growth in the coming years.

\subsection{Progress in debt reduction to date}

17. As of end-2012, only two countries of the sample covered where debt increased strongly before the crisis - the United Kingdom and the United States - have engaged in significant household debt reduction, cutting household debt-to-income ratios by more than 20 percentage points since 2007 (Table 1). Other countries having experienced a credit boom over the past decade have barely begun debtreduction processes (Canada, Ireland, Spain, Portugal) or are still accumulating debt in proportion of disposable income. In Belgium, France, Korea, the Netherlands, and Switzerland, household debt ratios are for instance still rising according to the latest available data (Figure 2). In Japan and Germany, where household indebtedness was on a declining path prior to the crisis, the debt-to-income ratio continued to edge down after the onset of the crisis.

18. The United States seems today to be the only country following a clear path of deleveraging. All categories of private-sector debt have decreased as a per cent of GDP since 2008:

- Household debt has fallen by $6 \%$ in absolute terms from its peak of 2007 and may further decrease by an equivalent amount in the near future as 254 billion dollars of troubled mortgages still in the foreclosure pipeline are likely to be discharged (MGI, 2012) and 250 billion dollars will be written off as part of a settlement with banks in relation to wrongful foreclosure practices (see below). ${ }^{8}$ The drop in the debt-to-disposable income ratio has been accompanied by a rise of the gross personal saving rate from $5.9 \%$ in 2005 to $9.3 \%$ in 2010 , with the associated drag for economic growth (Glick and Lansing, 2011). The saving ratio has however declined by more than one percentage point since then.

- Debt ratios of non-financial companies have also decreased and are now below their pre-boom levels (Figure 5 and Table 1).

- In the financial sector, debt has fallen back below its 2000 level, declining from 8 to 6.1 trillion dollars, with about 1 trillion dollars of this fall attributable to write-offs related to the collapse of Lehman Brothers, JP Morgan Chase's purchase of Bear Sterns, and the Bank of America-Merrill

8. MGI (2012) reports that defaults may have contributed for two-thirds to the decline of US household debt over 2008-2011. This estimate contrasts somewhat with Bhutta's (2012) finding based on individual credit records data that the decline in households' debt is mainly explained by lower credit growth rather than by larger debt repayments and more mortgage defaults. A proper estimate of the contribution of rising defaults to debt decline indeed requires dividing the crisis-related increase in charge-offs observed from 2008 to 2011 by the gap between the debt level that would have prevailed at the end of 2011 if all conditions - debt repayments, new borrowings and defaults - had remained the same as in the pre-crisis period and the actual level of debt in 2011. Such a calculation based on estimates of changes in charge-offs of Bhutta (2012) indicates that rising charge-offs made up $27 \%$ of the household debt reduction observed in the United States from 2008 to 2011 . 
Lynch merger (MGI, 2012). Within their liabilities, banks in the United States have also relied more on deposits and less on market debt to fund their activities since 2008.

19. In the United Kingdom, progress in deleveraging has differed across sectors:

- Even if there has been a significant reduction in household debt relative to disposable income, debt has increased in absolute terms, as the fall in consumer credit has been accompanied by an expansion of residential mortgage lending. Slower household deleveraging compared with the United States can partly be attributed to the relatively small number of troubled mortgages that have progressed to foreclosure so far. ${ }^{9}$ The adjustment in indebtedness has gone hand-in-hand with a rise in the household gross saving rate from $1.7 \%$ in 2007 to $7.1 \%$ in 2012 .

- The share of non-financial corporate debt in gross operating surplus has declined since 2009 but remains well above its 2000 level.

- Notwithstanding UK banks having reduced lending and raised capital, debt in the financial sector has continued to increase relative to GDP from an already very high level at the onset of the crisis (Figure 7).

20. In Ireland, Portugal and Spain, household debt has started to decline as a ratio to -disposable income though not as much as in the United States and the United Kingdom. The fall has been smaller mainly due to a denominator effect asdisposable income has dropped since the onset of the crisis in Ireland, Portugal and Spain. In absolute terms, households' debt in these three euro area countries has however significantly decreased from its peak level (respectively by 13, 7 and 6 per cent). Greece has also experienced a significant downward adjustment in household debt but at the same time a much larger decline in disposable income, leading to a still rising debt ratio.

\subsection{Assessing the potential for debt reduction}

21. An assessment of consolidation needs in the different sectors of the selected OECD economies requires an estimate of the appropriate debt level. In principle, such estimates should be derived from a model incorporating the key determinants of debt, with the determinants set at steady state or appropriate levels. Such models have yet to be developed.

22. In the absence of an appropriate economic model to assess the extent of deleveraging risks, a simple approach is adopted here by comparing end-2012 levels of the debt ratios with their pre-boom levels of 2000. This provides a conservative benchmark as equilibrium debt-to-income ratios may have changed, for example due to financial innovation and asset developments, and the extent of the possible reduction would change if e.g. trend levels were used as benchmarks. However, it is in line with the finding that increases in debt-to-GDP ratios preceding financial crises have tended to be reversed subsequently (Tang and Upper, 2010). The assessment is more precisely based on comparing gross debt-to-disposable income ratios of households, gross debt-to-gross operating surplus ratios of nonfinancial corporations, and gross debt-to-GDP ratios of financial corporations at the end of 2012 with their respective pre-boom levels.

9. However, this may change in the coming years according to MGI (2012) as the United Kingdom is estimated to have the same proportion of residential loans in some state of difficulty as the United States (14\% of mortgages outstanding). 
23. This approach allows identifying four groups of countries depending on the extent of their debtreduction potential in the private sector (Table 2):

- No reduction in indebtedness is expected in Japan, Germany, and Switzerland (with the exception of the financial sector in the two latter countries). ${ }^{10}$

- A mild reduction in indebtedness is possible in the United States.

- Significant cuts in indebtedness may occur in Belgium, Canada, the Netherlands, and Portugal, where households and/or corporations could potentially reduce their debt ratios by more than one-fifth. ${ }^{11}$

- Major reductions in indebtedness are plausible in Australia, France, Greece, Ireland, Italy, Korea, Spain, Sweden, and the United Kingdom:

- In all these countries, households' debt-to-income ratios would have to fall by a significant amount - ranging from 20 to more than $70 \%$ - to attain their pre-boom levels.

- The non-financial corporate sector could reduce its debt level significantly in most of these nine countries.

- There is considerable potential for financial sector debt reduction in the nine countries, particularly Ireland and the United Kingdom.

In most countries, the potential fall in private sector indebtedness comes on top of necessary medium- and long-term reductions in public sector debt.

\subsection{Future debt reduction in the household sector: Strategies and economic consequences}

24. The likely forthcoming deleveraging may have significant economic consequences (see e.g. Koo, 2011) as household debt reduction tends to be accompanied by higher saving rates, ${ }^{12}$ increased default rates, depressed valuations of financial and real estate assets, and lower residential investment. These

10. Compared with other countries, Swiss households have moderately increased their debt-to-disposable income ratio since 2000 while also enjoying the highest net financial position (Table 1).

11. In particular, Dutch households would need to reduce their debt dramatically to return the debt ratio to its 2000 level; however, given the strong increase in the ratio of assets to income in the past decade and with the pension system having been put on a sound footing, they are in a better position to carry higher gross debt.

12. Although there is no automatic link between debt and saving, a number of reasons may explain this negative relationship. First, deleveraging episodes are often associated with depressed labour markets and higher uncertainty leading to higher precautionary saving. Accordingly, at least two-fifths of the increase in saving observed in 2007-2009 in OECD countries have been estimated to be due to higher unemployment risk and GDP volatility (Mody et al., 2012). Second, a tightening of credit conditions is typically accompanied by a reduction in debt and an increase in saving as households cannot borrow as easily as before to offset negative income shocks (Mody et al., 2012). Third, house price declines are associated with lower debt and reduce the availability of home-equity-based borrowing, leading to lower consumption (Mian et al., 2011). Finally, households may target a given level of leverage and reduce their consumption to restore assets in response to a negative wealth shock (Carroll et al., 2012; Dynan, 2012; Mody et al., 2012). 
effects will however differ depending on the pace of debt reduction, the imbalances associated with the debt build-up, the country institutional settings, and the deleveraging strategies adopted. Some of this adjustment has already taken place with saving rates up and housing investment down in a number of OECD countries.

25. Changes in saving rates, residential investment and housing prices around household-debt turning points vary across countries, with different channels at play. In countries where the rise in indebtedness is primarily accompanied by higher building activity, the subsequent debt reduction is accompanied by massive lay-offs in the construction sector, rising non-performing loans from real estate businesses, and material losses for banks. In countries where the debt build-up mostly translates into property prices, declining house prices alone are primarily accompanied by wealth effects weighing on consumption, although some distributional and second-round effects remain. These different evolutions may partly reflect different institutional settings. In particular:

- Saving rates tend to be more volatile in countries with more risk related to labour income, for example where unemployment benefit replacement rates and job protection are lower. Likewise, compared with the United States (Mian et al., 2011 and Midrigan and Philippon, 2011), the decline in consumption resulting from a reduction in home equity-based borrowing is likely to be much smaller in continental European countries where home equity borrowing is relatively marginal.

- Household debt may be more correlated with housing prices than residential investment in countries where construction is constrained. Counties in the United States with relatively less elastic housing supply have for instance shown stronger house price appreciation and higher household debt ratios during the recent housing boom (Mian and Sufi, 2011) while in the Netherlands, the significant rise in housing prices has been accompanied by a relatively modest increase in residential investment over 1997-2007.

26. Negative effects associated with declining household debt ratios have already been observed in Ireland, Portugal, the United Kingdom and the United States where gross saving rates increased by 1.2 to 5.5 percentage points over 2007-2012 after having decreased by 1.5 to 9.4 percentage points over 19972007 (Table 3). Saving rates have also increased since 2007 in several countries with still rising debt ratios (Australia, Canada, France, Korea, and Sweden), as a result of precautionary saving related to the economic downturn with no direct connection to a deleveraging process (Figure 10). Historically, data show only a weak relationship between declines in debt ratios and saving rates (Figure 11, top panel). One reason is that saving rates tend to react strongly to economic conditions for precautionary motives (Mody et al., 2012) while in some countries debt ratios are more sluggish and may start declining several years after the economic downturn. Besides, in countries where saving rates did not decrease significantly or even increased during the period of debt build-up (Australia, Belgium, France, Sweden), there is little reason to expect saving to rise significantly when debt ratios decline.

27. Another growth-dampening effect generally associated with household deleveraging is depressed residential investment (Figure 11, bottom panel) as household debt and housing investment are both strongly correlated with housing prices (André, 2010) and credit conditions. Housing investment reversals however often precede declines in debt ratios so that deleveraging cannot be considered as a good predictor of residential investment. ${ }^{13}$ This lead-lag relationship may be explained by some forward-looking behaviour on the part of real estate developers combined with home sellers tending to wait before accepting to mark down their prices. Accordingly, with the exception of Canada, housing investment has

13. In the United Kingdom and Norway, for instance, residential investment started declining in 1989 and 1988 respectively, but housing prices and debt ratios decreased only one year later in each country. 
already experienced a sharp correction in many countries (Figure 12), even in those where debt ratios continued to rise after 2007 (Australia, Belgium, France, Italy, Korea, and the Netherlands), so that no major further declines are expected as deleveraging efforts progress.

\subsection{Deleveraging in the financial sector}

28. The macroeconomic effects of further debt reduction and deleveraging in the financial sector depend importantly on how it takes place. A reduction in the asset-to-equity ratio in the financial sector by raising equity would imply relatively small adverse growth effects in the short and medium term as the corresponding increase in the cost of capital would be relatively small. On the other hand, if adjustments are based on reducing assets, notably loans to the non-financial sector, to well below demand by households and businesses, this would cause a credit crunch with serious adverse consequences for growth.

\section{An important policy implication: the need to complete the cleaning of bank balance sheets}

29. Economic policy has an active role to play in the face of deleveraging pressures. Monetary policy has to take into account the consequences for activity of efforts by the private sector to reduce its indebtedness, and has been doing so in recent years in some countries as discussed in OECD (2012). Financial policy that ensures a complete repair of the banking sector is essential to create a business environment compatible with rapid economic recovery: this section focuses on this point. Looking ahead, reforms in the areas of micro and macro-prudential regulation, fiscal policy, taxation and bankruptcy legislation, which are discussed in Sutherland et al. (2012) can help to prevent new dangerous debt run ups and damp the consequences of asset price crashes.

30. The most urgent priority for financial policy is to ensure that bad loans be recognised swiftly, losses be taken, insolvent banks wound down orderly and capital shortfalls be plugged at still solvent banks. International experience with banking crises shows that policies of regulatory forbearance, often introduced to buy time, actually only lengthen the period of weakness and increase the overall economic and budgetary cost of the crisis (see Box 1 ).

31. Near-zero interest rate policy and ample liquidity exacerbate the need for supervisors to check that banks duly recognise and deal with bad loans. In an environment of low interest rates, high liquidity provision by central banks and scarce equity capital, the opportunity cost for a bank of rolling over doubtful loans is low when compared with the alternative option of recognising it and having to take capital-depleting provisions and write-offs. In the low-interest rate environment of Japan, there is evidence that weakening industries received a disproportionate share of loans, to the detriment of competition and investment by new entrants (BIS, 2010; Caballero et al., 2008; Watanabe, 2010). The capital misallocation associated with such "ever-greening" of bad loans can lastingly depress total factor productivity growth as seems to have occurred in Japan (Barseghyan, 2010).

32. Based on the limited available data allowing historical comparisons, there are signs in some countries that recognised bad loan rates in the latest published data may be low when set against the depth of the recent recession. In the United States, for which long time-series exist, such signs are less obvious with the share of delinquent loans in total loans recently peaking at a level that seems broadly consistent with its historical relationship vis-a-vis the output gap (Figure 7, Panel A). By contrast, in France and Germany, recognised non-performing loans are below their levels in the early 2000s despite a much weaker economic situation. And a number of countries have registered only very modest increase in nonperforming loans despite much more pronounced weakness than in the early 2000s. These rough comparisons suggest that low interest rates might have reduced the recognition of bad loans, underscoring the need for active supervision to enforce the recognition of non-performing loans where needed. In Japan, bad loans have edged up during the recent crisis but remain well below their levels at the turn of the century, when they were inflated by delayed supervisory response to the previously bursted bubble. 
33. Recognising bad loans implies a need to take write-offs subsequently. In Sweden, banks took losses equivalent to $17 \%$ of lending over 1990-93 (Englund, 1999). For the sake of illustration, applying such a loss rate to the pre-crisis stock of loans to households and non-financial corporations would mean write-offs equivalent to almost $20 \%$ of GDP in many large OECD economies. To a large extent, given that many banks still fall well short of the $5 \%$ ratio of core capital to assets identified as a benchmark for well capitalised banks (Blundell-Wignall and Atkinson, 2012; OECD, 2012b), write-offs not offset by earnings have to be compensated with new capital. Some progress has been made in this regard but if, going forward, finding equity in the markets proves difficult for banks, their recapitalisation might have to come from the public purse. This would imply a considerable outlay for already stretched public finances but it might nevertheless be warranted given the even larger ultimate cost to public finances of not recognising losses and accumulating government deficits associated with protracted economic weakness. In Japan, where the recognition and write-off of bad loans was much more delayed than in Sweden, losses cumulated over 1992 to 2008 amounted to 34\% of bank loans (Hoshi and Kashyap, 2008).

\section{Box 1. Dealing with bank deleveraging: Sweden vs. Japan and Chile vs. Mexico}

The experience of Sweden in its 1990-93 banking-crisis recession shows that a rapid acknowledgement of losses and banking sector restructuring can help to restart growth quickly and to put public debt on a rapidly declining trend. In contrast, the more dragged out process of loss recognition and banking resolution in Japan in 1992-02 meant low growth and a massive increase in government indebtedness followed by only a modest rebound. In particular:

- In Japan, private-sector debt reduction did not really begin until nearly eight years after the crash at the start of the 1990s. In the years following the bursting of the asset price bubble, the large debt accumulated by Japanese non-financial companies weighed on their ability to invest while impaired bank balance sheets, burdened by a large number of non-performing loans, reduced the supply of credit. At the same time, Japan's public debt grew steadily to sustain the economy. Although Japan avoided a sovereign debt crisis thanks to the willingness of Japanese investors to hold a large share of public debt, the ratio of public debt to GDP is today much higher than in any euro area crisis country and the sustainability of government debt remains an important issue (see e.g. OECD, 2011).

- In Sweden, the deleveraging process was, in contrast, much more rapid, thanks to an early recognition of problems and a prompt public intervention, resulting in a solid economic recovery (see for instance Borio et al., 2010). Households reduced their debt by $40 \%$ of their disposable income over 6 years while in Japan the household deleveraging process lasted only two years with a reduction of only $5 \%$ (Figure 2). The Swedish experience suggests that successful deleveraging should follow two phases. In a first phase, private debt should be reduced, while economic growth is negative and public debt rises. The ratio of private-sector debt to GDP declined in Sweden by one-fourth while household debt to GDP declined even more sharply thanks to rising nominal GDP in a context of devaluation-induced increase in inflation. Weak economic growth, falling tax revenue and growing public expenditures to support the economy, however, led to a sharp increase in public debt, from $46 \%$ of GDP in 1990 to $83 \%$ in 1994 (Figure 14). In a second phase of the deleveraging process, public debt should be progressively reduced as economic growth rebounds.

It should be noted, however, that the environment facing today's deleveraging economies differs from the Swedish one of the 1990s in several respects. The Swedish recovery was helped by significant currency depreciation and a lasting fall in the real effective exchange rate (which since 1993 has remained on average $20 \%$ below its level in the two decades before 1992). The recovery of the economy in 1994 was essential to reduce the ratio of public debt to GDP, which felt from $84 \%$ in 1996 to $50 \%$ in 2008. Most OECD economies entered the recent crisis with higher and rising public debts and large structural deficits. While exports were a key driver of Swedish growth recovery - in particular thanks to currency depreciation and strong global demand - today's economies face much weaker global growth and are less open than Sweden so currency adjustment would be less effective (and would in any case be less likely given that a large share of the OECD economy is affected by the aftermath of the crisis) even if such adjustments were possible. Finally, the need to maintain credibility with investors in an environment of heightened concern about sovereign risk may force some countries into public sector deleveraging at a faster pace than what would otherwise be optimal.

Countries in need to reduce their indebtedness at the time of writing also face a different environment from that of Japan in the 1990s. In particular, the asset price appreciation has been more modest, notably concerning equity valuations, and monetary and fiscal policies have been more responsive. Some (but not all) of the countries that have already reduced debt ratios or are likely to do so in the future also have more flexible product and labour markets than Japan in the 1990s. It is also the case that the need for deleveraging in the non-financial sector was more focused on the enterprise sector and less on the household sector in Japan than in other countries at the end of 2012, although the consequences of this difference are unclear. 


\section{Box 1. Dealing with bank deleveraging: Sweden vs. Japan and Chile vs. Mexico (cont.)}

To give two other examples, in the early 1980s, Chile and Mexico experienced debt crises followed by banking distress which resulted in governments acquiring most or all (respectively) of the banking sector. In Chile, the government cleaned balance sheets of banks and then quickly sold them while in Mexico banks were kept under government ownership for about a decade, loss recognition was slower and lending was allocated on the basis of industrial-policy criteria (Bergoeing et al., 2007; Brock, 2009). In Chile, the swift resolution of banks accompanied by an active process to liquidate bad loans, including bankruptcy reform, was followed by rapid growth while in Mexico the provision by government-owned banks of credit below market interest rates to selected firms was accompanied by GDP per capita contracting over the 1982-1995 period (Córdoba and Kehoe, 2009).

34. Where governments have taken ownership of much of the banking sector, such as in the United Kingdom, international experience makes a strong case for resolving and selling banks quickly. Prolonged government control of the banking sector can result in lending decisions based on industrial-policy rather than market considerations, a lack of recognition of bad loans and/or ultimate large losses. The successful experiences of Chile and Sweden, for instance, show the benefits of winding down or cleaning banks' balance sheets swiftly before selling them quickly to private investors. 
ECO/WKP(2013)69

Table 1. Private sector: Debt and balance-sheet indicators

(per cent)

\begin{tabular}{|c|c|c|c|c|c|c|c|c|c|c|c|c|}
\hline & \multicolumn{12}{|c|}{$\begin{array}{l}\text { Household } \\
\end{array}$} \\
\hline & \multicolumn{4}{|c|}{ Debt-to-gross disposable income ratio } & \multicolumn{4}{|c|}{ Net financial wealth-to-gross disposable income ratio } & \multicolumn{4}{|c|}{ Debt over net worth ratio } \\
\hline & $2012^{2}$ & $\begin{array}{c}\text { Long- } \\
\text { term } \\
\text { trend } \\
2012\end{array}$ & $\begin{array}{l}\text { Pre- } \\
\text { crisis } \\
\text { level } \\
2007\end{array}$ & $\begin{array}{c}\text { Pre- } \\
\text { boom } \\
\text { level } \\
2000\end{array}$ & $2012^{2}$ & $\begin{array}{c}\text { Pre-crisis } \\
\text { level } \\
2007 \\
\end{array}$ & $\begin{array}{c}\text { Average } \\
\text { level 1980- } \\
2000^{3}\end{array}$ & $\begin{array}{c}\text { Pre-boom } \\
\text { level } \\
2000 \\
\end{array}$ & $2012^{2}$ & $\begin{array}{c}\text { Long- } \\
\text { term } \\
\text { trend } \\
2011 \\
\end{array}$ & $\begin{array}{l}\text { Pre- } \\
\text { crisis } \\
\text { level } \\
2007\end{array}$ & $\begin{array}{c}\text { Pre- } \\
\text { boom } \\
\text { level } \\
2000\end{array}$ \\
\hline USA & 108 & 116 & 131 & 96 & 328 & 347 & 275 & 346 & 20 & 19 & 22 & 17 \\
\hline Euro area & 108 & na & 104 & 82 & 206 & 208 & na & 215 & 17 & na & 16 & 16 \\
\hline Japan & 124 & 169 & 127 & 134 & 373 & 374 & 215 & 302 & 18 & 21 & 17 & 20 \\
\hline Germany ${ }^{1}$ & 87 & 156 & 96 & 109 & 189 & 182 & na & 144 & 15 & 26 & 17 & 22 \\
\hline France & 101 & 93 & 89 & 68 & 215 & 213 & 149 & 214 & 13 & 18 & 11 & 12 \\
\hline Italy & 74 & 60 & 66 & 42 & 247 & 273 & 188 & 315 & 9 & 8 & 8 & 6 \\
\hline United Kingdom & 146 & 146 & 174 & 112 & 286 & 287 & 242 & 363 & 21 & 19 & 22 & 16 \\
\hline Canada & 149 & 145 & 135 & 110 & 202 & 207 & & 234 & 28 & 25 & 25 & 22 \\
\hline Australia & 171 & 137 & 170 & 114 & 166 & 210 & 110 & 152 & 26 & 32 & 22 & 19 \\
\hline Belgium & 91 & 81 & 80 & 65 & 346 & 359 & & 437 & 27 & 32 & 12 & 10 \\
\hline Greece & 98 & na & 72 & 27 & 83 & 129 & na & 200 & na & na & na & na \\
\hline Ireland & 210 & na & 218 & 94 & 161 & 111 & na & na & na & na & na & na \\
\hline Korea & 153 & 140 & 139 & 92 & 177 & 162 & 91 & 139 & 25 & 27 & 21 & 18 \\
\hline Netherlands & 284 & 186 & 242 & 164 & 398 & 344 & 310 & 407 & 31 & 21 & 27 & 19 \\
\hline Portugal & 133 & 124 & 142 & 104 & 180 & 179 & 151 & 212 & 30 & 23 & 29 & 21 \\
\hline Spain & 131 & 97 & 140 & 82 & 119 & 144 & 129 & 167 & 15 & 14 & 13 & 13 \\
\hline Sweden & 168 & 98 & 154 & 105 & 237 & 214 & 108 & 215 & 38 & 22 & 34 & 28 \\
\hline Switzerland & 195 & 193 & 207 & 248 & 353 & 400 & na & 407 & 25 & na & 24 & 23 \\
\hline
\end{tabular}

1. Break in series 1991 due to change in classification and unification. For Germany, the long-term trend and the average level are calculated over the period 1991-2000.

2. Or latest available.

3. The average level for the Netherlands and Belgium, are calculated respectively over the period 1990-2000 and 1994-2000 and for Australia over the period 1989-2000.

Source: OECD national accounts, OECD Economic Outlook 90 database, national central banks, national statistical institutes, ECB, Eurostat and, for Belgium and the Netherlands, OECD calculations on the basis of Cecchetti et al. (2011). 
Table 1. Private sector: Debt and balance-sheet indicators (cont.)

\begin{tabular}{|c|c|c|c|c|c|c|c|c|}
\hline & & & & $\begin{array}{l}\text { er cent) } \\
\text { lon-financial }\end{array}$ & rporatio & & & \\
\hline & \multicolumn{4}{|c|}{ Debt-to-gross operating surplus ratio } & \multicolumn{4}{|c|}{ Debt-to-equity ratio } \\
\hline & $2012^{2}$ & $\begin{array}{l}\text { Pre-crisis } \\
\text { level } 2007\end{array}$ & $\begin{array}{c}\text { Average } \\
\text { level 1980- } \\
2000^{3} \\
\end{array}$ & $\begin{array}{l}\text { Pre-boom } \\
\text { level } 2000 \\
\end{array}$ & $2012^{2}$ & $\begin{array}{l}\text { Pre-crisis } \\
\text { level } 2007\end{array}$ & $\begin{array}{c}\text { Average } \\
\text { level 1980- } \\
2000^{3}\end{array}$ & $\begin{array}{l}\text { Pre-boom } \\
\text { level } 2000\end{array}$ \\
\hline USA & 735 & 813 & 728 & 849 & 0.6 & 0.6 & 1 & 0.6 \\
\hline Euro area & 513 & 446 & na & 405 & 1.0 & 0.8 & na & 0.7 \\
\hline Japan & 678 & 661 & 865 & 825 & 1.6 & 1.5 & 2.4 & 1.9 \\
\hline Germany ${ }^{1}$ & 326 & 308 & 367 & 388 & 0.9 & 0.8 & 1.5 & 0.9 \\
\hline France & 792 & 554 & 507 & 534 & 0.9 & 0.6 & 1.8 & 0.6 \\
\hline Italy & 516 & 426 & 261 & 297 & 1.1 & 0.9 & 1.2 & 0.7 \\
\hline United Kingdom & 669 & 607 & 409 & 489 & 0.8 & 0.8 & 0.9 & 0.5 \\
\hline Canada & 411 & 389 & 532 & 450 & 0.8 & 0.8 & 1.7 & 1.3 \\
\hline Australia & 395 & 419 & 483 & 382 & 0.7 & 0.5 & 0.8 & 0.7 \\
\hline Belgium & 458 & 347 & 357 & 438 & 0.4 & 0.4 & 0.8 & 0.6 \\
\hline Greece & 364 & 327 & na & 268 & 2.1 & 1.0 & na & 0.7 \\
\hline Ireland ${ }^{3}$ & 685 & 537 & na & 479 & 1.2 & 1.6 & na & 1.3 \\
\hline Korea & 674 & 630 & 714 & 739 & 1.3 & 1.1 & 3.5 & 3.0 \\
\hline Netherlands & 529 & 503 & 517 & 615 & 0.9 & 0.9 & 1.2 & 0.9 \\
\hline Portugal & 844 & 739 & na & 631 & 1.5 & 1.1 & na & 1.0 \\
\hline Spain & 562 & 781 & na & 413 & 1.4 & 1.1 & 0.7 & 0.8 \\
\hline Sweden & 736 & 624 & 667 & 795 & 0.7 & 0.8 & 2.3 & 1.2 \\
\hline Switzerland & 448 & 410 & na & 469 & 0.6 & 0.4 & na & 0.4 \\
\hline
\end{tabular}

1. Break in series 1991 due to change in classification and unification. For Germany, the long-term trend and the average level are calculated over the period 1991-2000.

2. Or latest available.

3. The average level for the Netherlands and Belgium, are calculated respectively over the period 1990-2000 and 1994-2000 and for Australia over the period 1989-2000.

Source: OECD national accounts, OECD Economic Outlook 90 database, national central banks, national statistical institutes, ECB, Eurostat and , for Belgium and the Netherlands, OECD calculations on the basis of Cecchetti et al. (2011). 
Table 1. Private sector: Debt and balance-sheet indicators (cont.)

(per cent)

\begin{tabular}{|c|c|c|c|c|c|c|c|c|}
\hline & \multicolumn{8}{|c|}{ Financial corporations } \\
\hline & \multicolumn{4}{|c|}{ Debt-to-GDP ratio } & \multicolumn{4}{|c|}{ Financial assets-to-equity ratio } \\
\hline & $2012^{2}$ & $\begin{array}{l}\text { Pre-crisis } \\
\text { level } 2007\end{array}$ & $\begin{array}{c}\text { Average } \\
\text { level 1980- } \\
2000^{3}\end{array}$ & $\begin{array}{c}\text { Pre-boom } \\
\text { level } 2000 \\
4\end{array}$ & $2012^{2}$ & $\begin{array}{l}\text { Pre-crisis } \\
\text { level } 2007 \\
\end{array}$ & $\begin{array}{c}\text { Average } \\
\text { level 1980- } \\
2000^{3}\end{array}$ & $\begin{array}{c}\text { Pre-boom } \\
\text { level } 2000 \\
4\end{array}$ \\
\hline USA & 315 & 335 & 210 & 277 & 3 & 3 & 7 & 3 \\
\hline Euro area & 480 & 428 & 283 & 287 & 3 & 3 & na & 3 \\
\hline Japan & 559 & 516 & 452 & 567 & 13 & 12 & 18 & 21 \\
\hline Germany ${ }^{1}$ & 334 & 322 & 202 & 290 & 6 & 5 & 6 & 5 \\
\hline France & 280 & 275 & 146 & 186 & 7 & 6 & 6 & 5 \\
\hline Italy & 219 & 179 & 102 & 125 & 17 & 5 & 5 & 2 \\
\hline United Kingdom & 835 & 803 & 388 & 568 & 13 & 11 & 11 & 6 \\
\hline Canada & 318 & 292 & 186 & 233 & 4 & 3 & 5 & 3 \\
\hline Australia & 318 & 318 & 193 & 228 & 6 & 5 & 8 & 5 \\
\hline Belgium & 305 & 392 & 193 & 275 & 8 & 6 & 7 & 5 \\
\hline Greece & 212 & 154 & na & 108 & 13 & 4 & na & 3 \\
\hline Ireland ${ }^{3}$ & 1073 & 931 & na & 452 & 2 & 3 & na & 3 \\
\hline Korea & 387 & 350 & 195 & 310 & 14 & 15 & 23 & 22 \\
\hline Netherlands & 664 & 670 & 429 & 491 & 4 & 5 & 4 & 4 \\
\hline Portugal & 277 & 258 & 61 & 202 & 6 & 5 & na & 5 \\
\hline Spain & 255 & 233 & 141 & 155 & 10 & 6 & 10 & 4 \\
\hline Sweden & 299 & 247 & 183 & 211 & 8 & 7 & 15 & 7 \\
\hline Switzerland & 544 & 612 & 531 & 539 & na & 4 & na & 4 \\
\hline
\end{tabular}

1. Break in series 1991 due to change in classification and unification. For Germany, the long-term trend and the average level are calculated over the period 1991-2000.

2. Or latest available.

3. The average level for the Netherlands and Belgium, are calculated respectively over the period 1990-2000 and 1994-2000 and for Australia over the period 1989-2000.

Source: OECD national accounts, OECD Economic Outlook 90 database, national central banks, national statistical institutes, ECB, Eurostat and, for Belgium and the Netherlands, OECD calculations on the basis of Cecchetti et al. (2011). 
Table 2. Debt reduction potentials as of end-2012

\begin{tabular}{|c|c|c|c|}
\hline & Households & $\begin{array}{c}\text { Non-financial } \\
\text { corporations }\end{array}$ & Financial corporations \\
\hline United States & + & - & + \\
\hline Euro area & ++ & ++ & +++ \\
\hline Japan & - & - & - \\
\hline Germany & - & - & + \\
\hline France & +++ & +++ & +++ \\
\hline Italy & +++ & +++ & +++ \\
\hline United Kingdom & ++ & +++ & +++ \\
\hline Canada & ++ & - & ++ \\
\hline Australia & +++ & + & ++ \\
\hline Belgium & ++ & + & + \\
\hline Greece & +++ & ++ & +++ \\
\hline Ireland & +++ & +++ & +++ \\
\hline Korea & +++ & - & ++ \\
\hline Netherlands $^{\top}$ & +++ & - & ++ \\
\hline Portugal & ++ & ++ & ++ \\
\hline Spain & +++ & ++ & +++ \\
\hline Sweden & +++ & - & ++ \\
\hline Switzerland $^{2}$ & - & - & + \\
\hline
\end{tabular}

Note: $\mathbf{-}, \mathbf{+}, \mathbf{+ +}$ and $\mathbf{+ + \boldsymbol { + }}$ denote, respectively, a potential of no, mild, significant, and major reduction of indebtedness. The assessment is based on comparing gross debt-to- gross disposable income ratios for households, gross debt-to-gross operating surplus ratios for non-financial corporations, and gross debt-to-GDP ratios for financial corporations at the end of 2012 with their respective pre-boom levels. A potential of debt reduction is identified as mild, significant, and major if the debt ratios have to decrease by 0 to $20 \%$, by 20 to $30 \%$ and by more than $30 \%$, respectively, to return to their pre-boom levels. Table 1 contains the data used for the comparison.

Source: OECD calculations. 
Table 3. Changes in household debt ratios, saving rates, housing investment and housing prices from 1997 to 2007 and from 2007 to 2012

\begin{tabular}{|l|c|c|c|c|c|c|c|c|}
\hline & \multicolumn{3}{|c|}{$\begin{array}{c}\text { Debt-to-income ratio } \\
\text { (p.p.) }\end{array}$} & \multicolumn{2}{c|}{$\begin{array}{c}\text { Gross saving-to-income } \\
\text { ratio (p.p.) }\end{array}$} & \multicolumn{2}{c|}{$\begin{array}{c}\text { Housing investment-to- } \\
\text { income ratio (p.p.) }\end{array}$} & \multicolumn{2}{c|}{$\begin{array}{c}\text { House price-to-income ratio } \\
\text { (\%) }\end{array}$} \\
\hline & $1997-2007$ & $2007-2012$ & $1997-2007$ & $2007-2012$ & $1997-2007$ & $2007-2012$ & $1997-2007$ & $2007-2012$ \\
\hline United States & 39.6 & -22.8 & -1.5 & 1.2 & 0.2 & -2.7 & 8.8 & -26.6 \\
\hline Japan & -1.2 & 3.8 & -7.7 & -0.5 & -1.8 & -1.0 & -27.5 & -12.4 \\
\hline Germany & -2.5 & -8.9 & 0.9 & -0.4 & -2.8 & 0.4 & -23.6 & 3.6 \\
\hline France & 23.5 & 12.0 & -0.4 & 0.4 & 2.4 & -1.0 & 65.9 & -5.5 \\
\hline United Kingdom & 70.7 & -28.3 & -6.5 & 5.5 & 4.9 & -4.4 & 87.0 & -18.5 \\
\hline Italy & 34.8 & 0.2 & -4.6 & -4.1 & 1.6 & -0.8 & 44.1 & -5.1 \\
\hline Canada & 27.9 & 13.4 & -0.7 & 1.2 & 4.2 & -0.5 & 15.3 & 2.2 \\
\hline Australia & 74.2 & 0.8 & 0.5 & 4.1 & 1.0 & -1.5 & 31.8 & -13.3 \\
\hline Belgium & 15.6 & 10.6 & -1.3 & -1.3 & 1.8 & -1.4 & 52.2 & 1.2 \\
\hline Greece & 56.1 & 29.2 & -5.8 & -14.6 & 6.0 & -12.0 & 42.2 & -2.4 \\
\hline Ireland & 147.2 & -3.9 & -9.4 & 3.5 & 11.4 & -18.3 & 69.9 & -46.5 \\
\hline Korea & 42.9 & 14.3 & -11.5 & 0.7 & -1.0 & -3.2 & -16.9 & -10.8 \\
\hline Netherlands & 117.5 & 42.8 & -4.8 & -2.5 & 2.6 & -4.2 & 49.3 & -12.6 \\
\hline Portugal & 69.8 & -7.1 & -3.9 & 4.7 & -3.5 & -4.0 & -15.0 & -0.8 \\
\hline Spain & 77.8 & -5.8 & -5.6 & -2.2 & 9.4 & -10.5 & 54.4 & -24.3 \\
\hline Sweden & 60.2 & 13.5 & 5.2 & 4.0 & 5.0 & -1.6 & 53.5 & -8.7 \\
\hline Switzerland & 11.5 & 13.9 & 1.7 & -2.0 & -0.5 & -0.1 & -10.0 & 11.1 \\
\hline
\end{tabular}

Source: OECD calculations. 
Figure 1. Domestic debt-to-GDP ratio of the non-financial economy

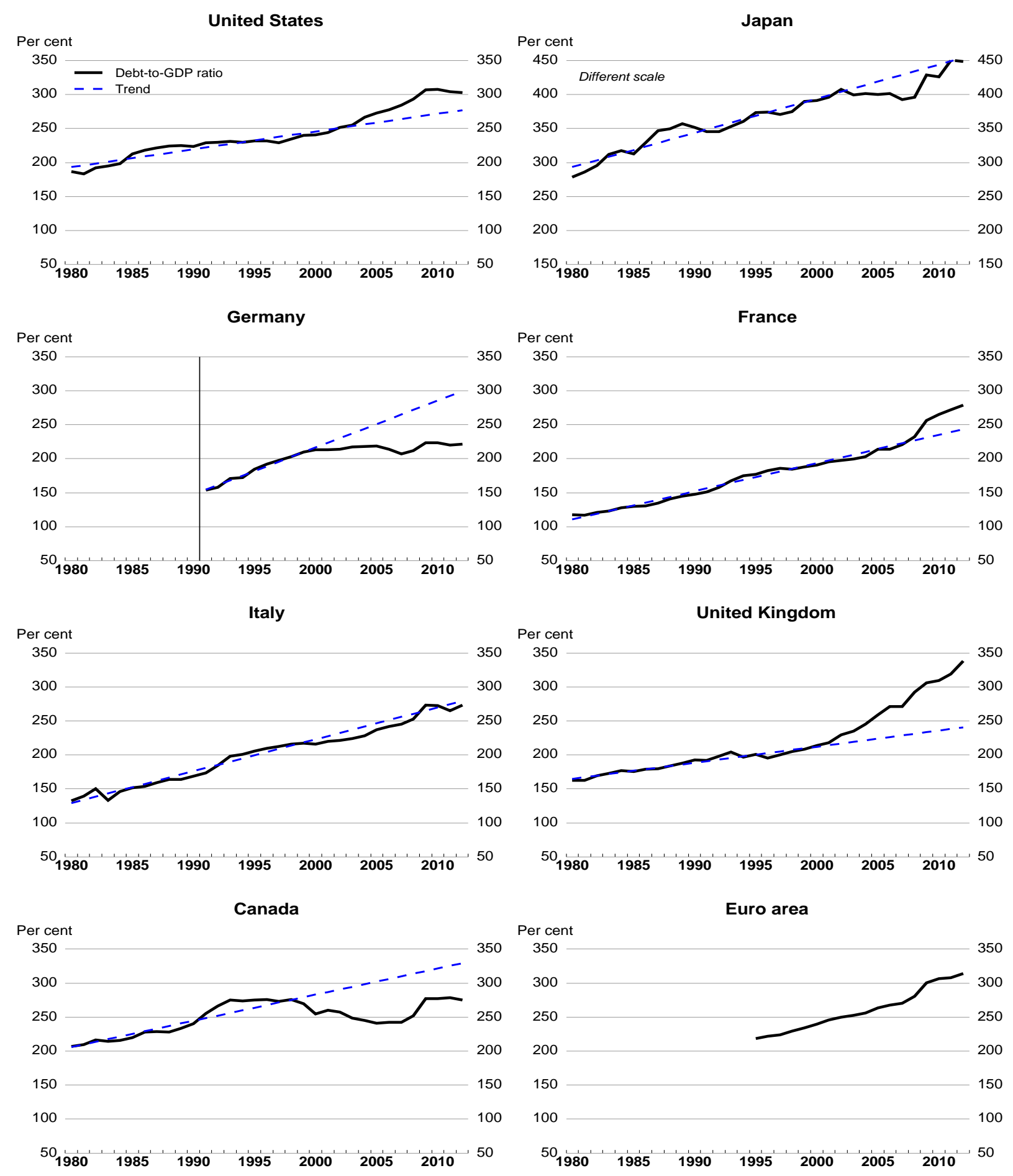

Note: Debt is calculated as total liabilities minus shares and other equities minus financial derivatives. Trend is OLS trend ratio computed over 1980 to 2000 if data are available, otherwise from the first year available to year 2000 .

Source: OECD national accounts, national statistical offices, national central banks, ECB, Eurostat, and OECD Economic Outlook database no. 93. 
Figure 1. Domestic debt-to-GDP ratio of the non-financial economy (cont.)
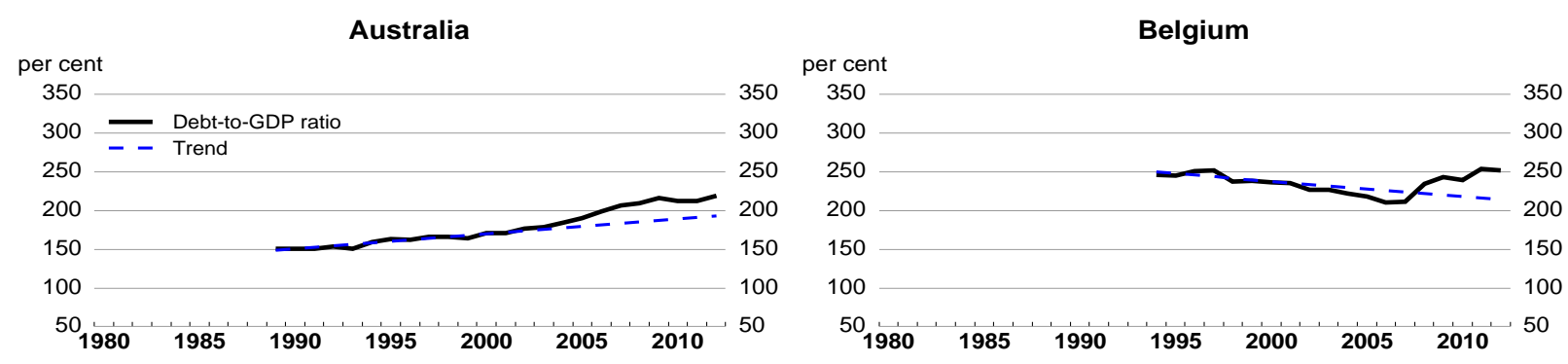

Greece
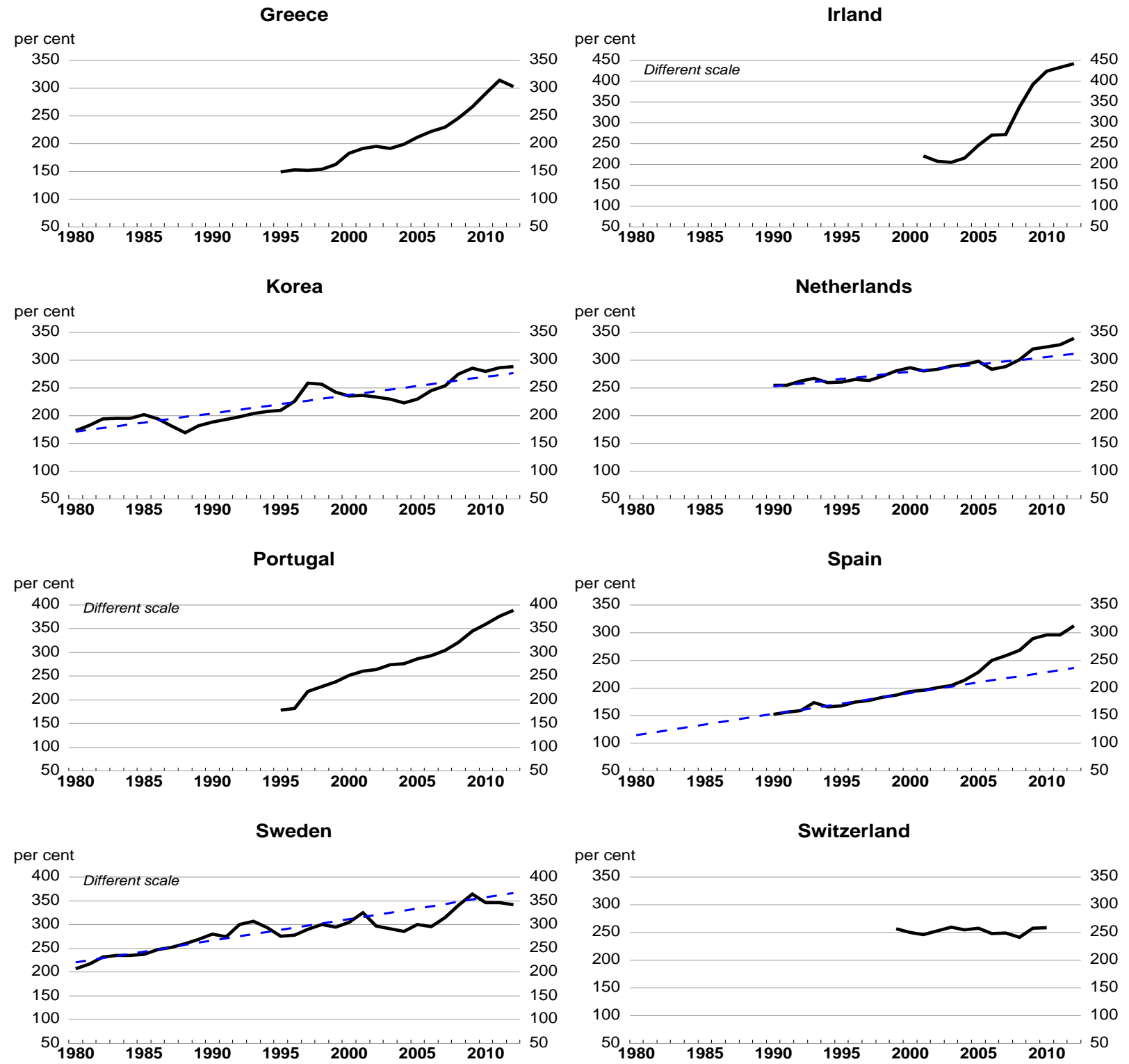

Note: Debt is calculated as total liabilities minus shares and other equities minus financial derivatives. Trend is OLS trend ratio computed over 1980 to 2000 if data are available, otherwise from the first year available to year 2000 .

Source: OECD national accounts, national statistical offices, national central banks, ECB, Eurostat, and OECD Economic Outlook database no. 93. 
Figure 2. Ratio of gross debt to disposable income for households
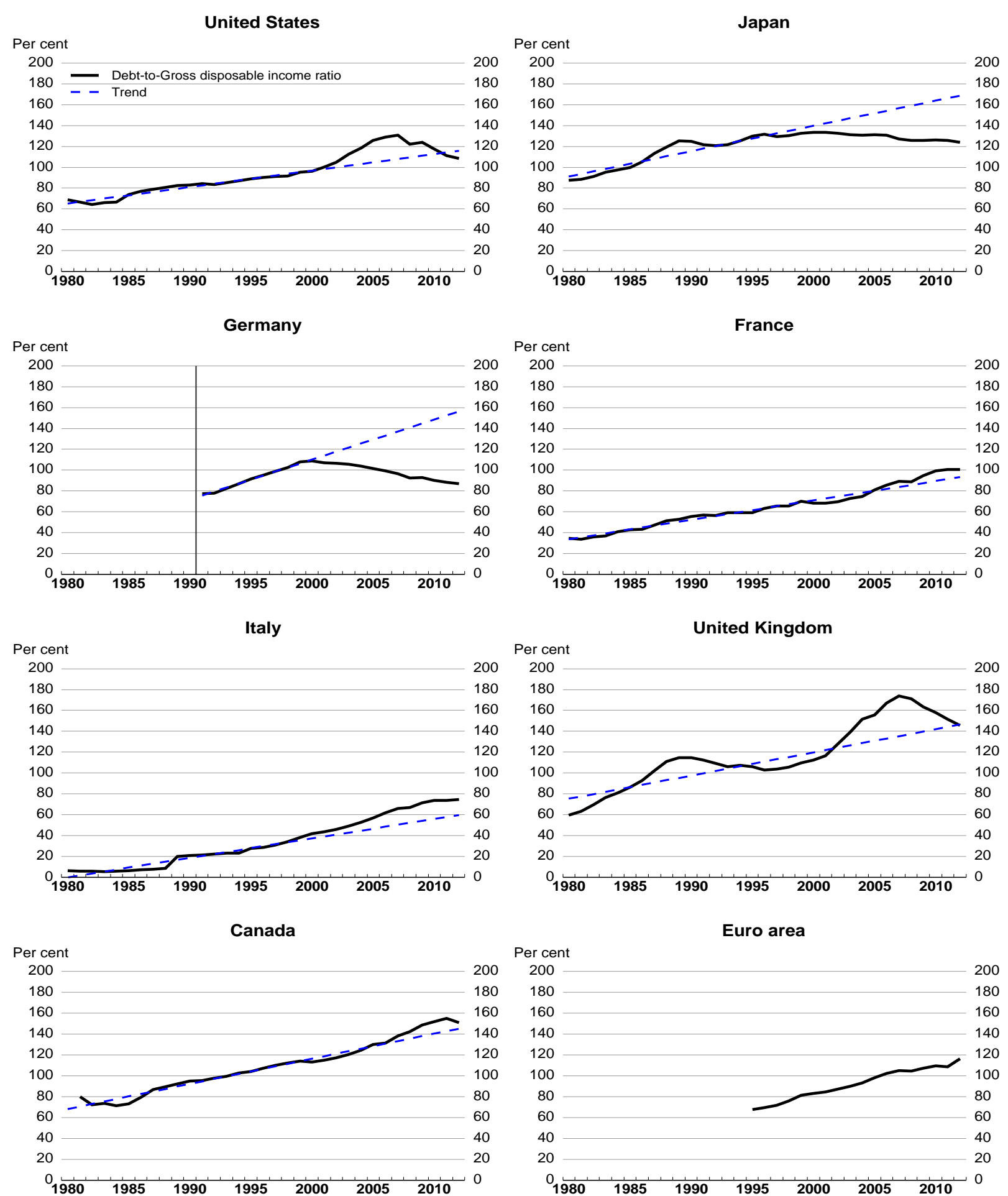

Note: Trend is OLS trend ratio computed over 1980 to 2000 if data are available, otherwise from the first year available to year 2000.

Source: OECD national accounts, national statistical offices, national central banks, ECB, Eurostat, and OECD Economic Outlook database no. 93. 
Figure 2. Ratio of gross debt to disposable income for households (cont.)
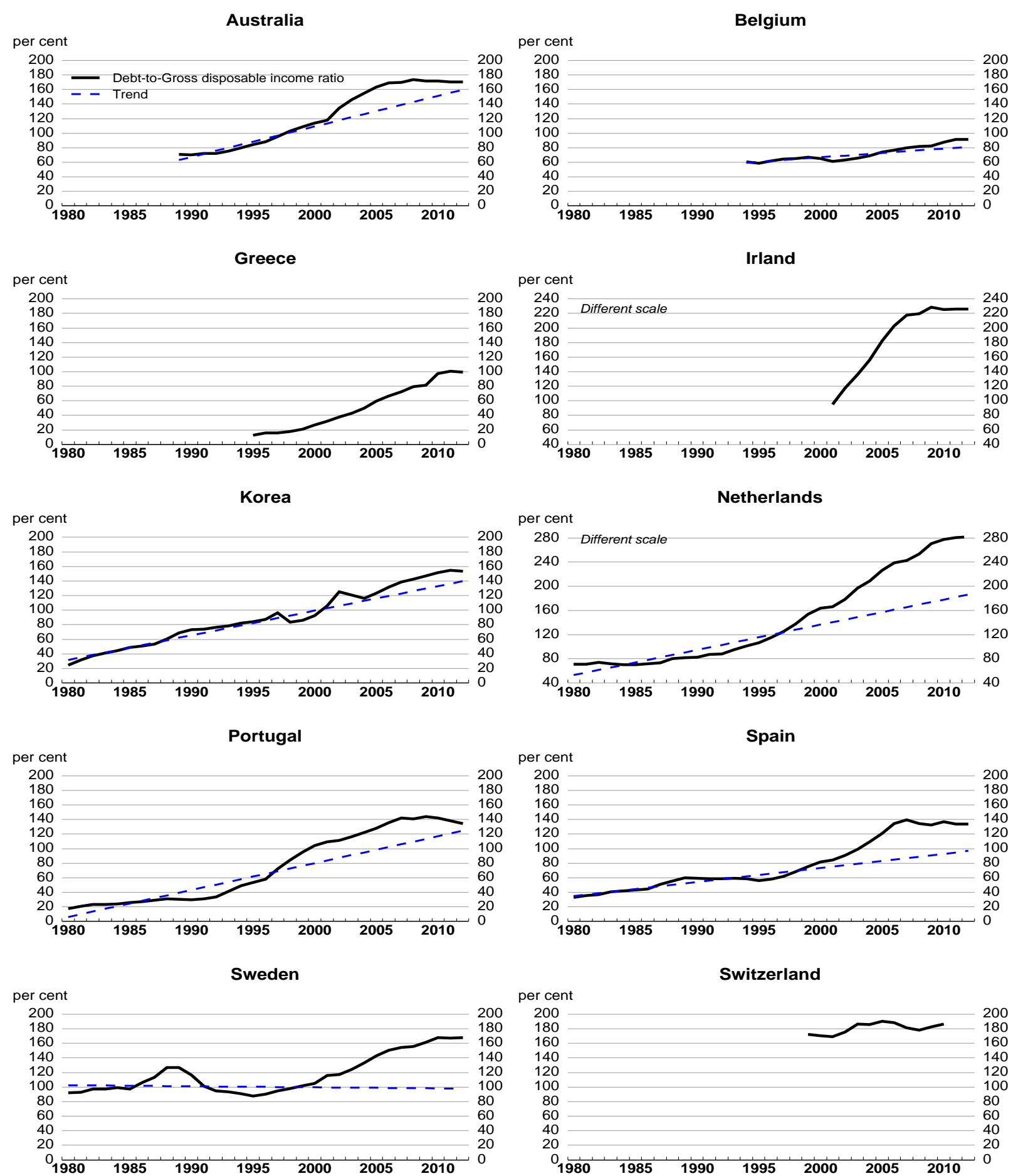

Note: Trend is OLS trend ratio computed over 1980 to 2000 if data are available, otherwise from the first year available to year 2000.

Source: OECD national accounts, national statistical offices, national central banks, ECB, Eurostat, and OECD Economic Outlook database no. 93. 
Figure 3. Ratio of net financial wealth to gross disposable income of households
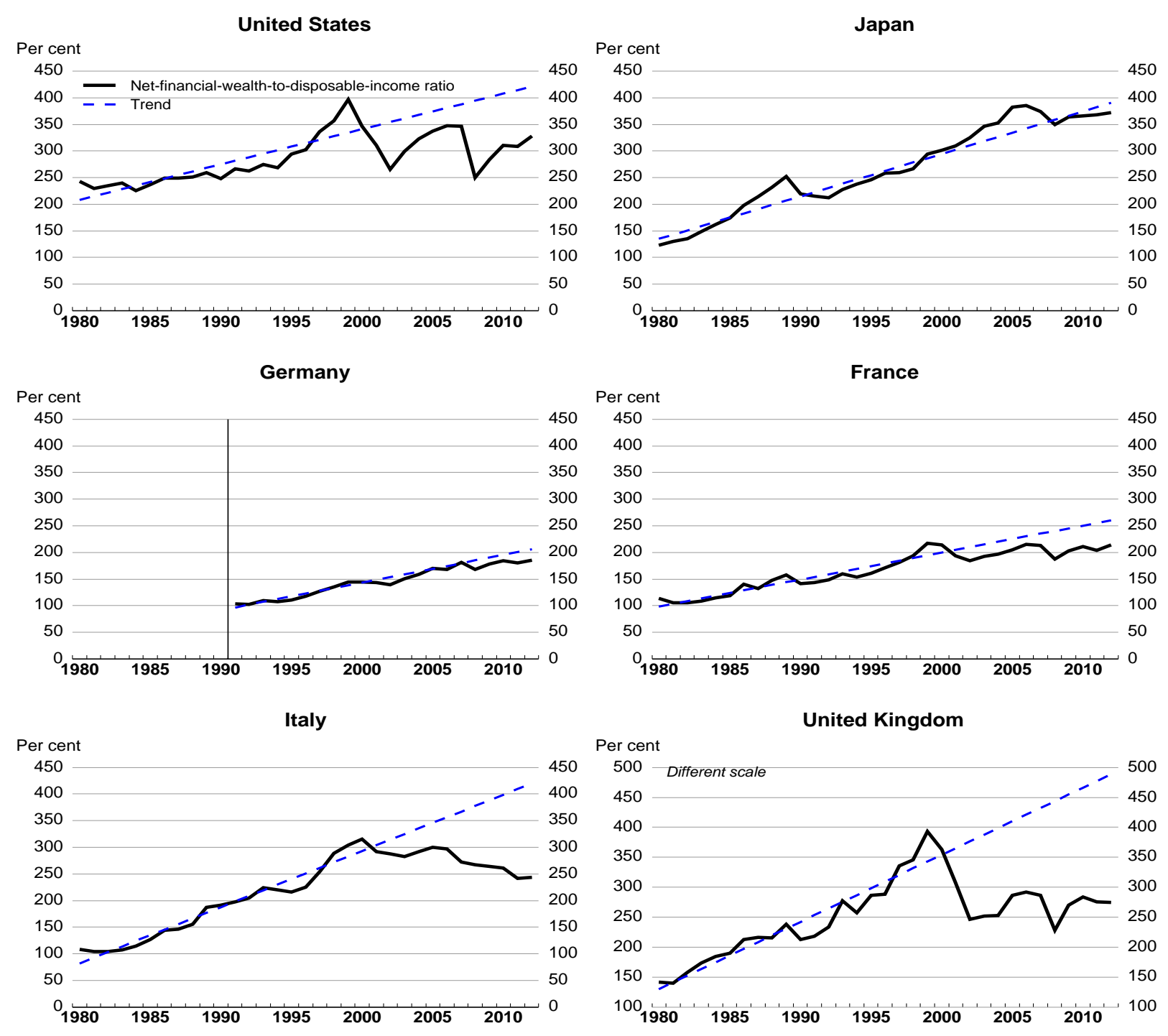

Canada
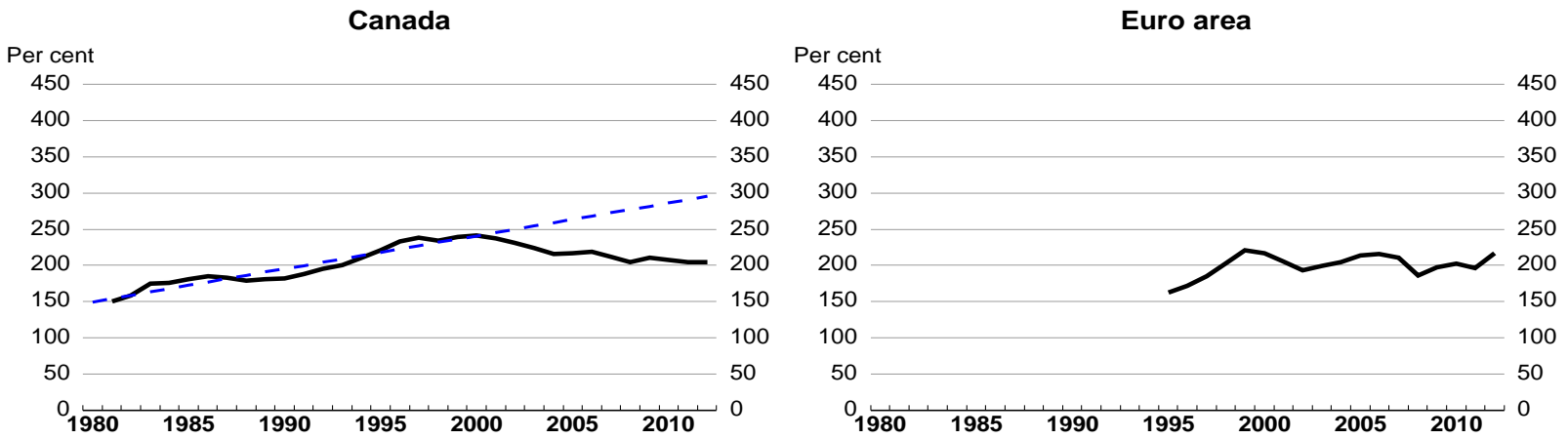

Note: Trend is OLS trend ratio computed over 1980 to 2000 if data are available, otherwise from the first year available to year 2000.

Source: OECD national accounts, national statistical offices, national central banks, ECB, Eurostat, and OECD Economic Outlook database no. 93. 
Figure 3. Ratio of net financial wealth to gross disposable income of households (cont.)
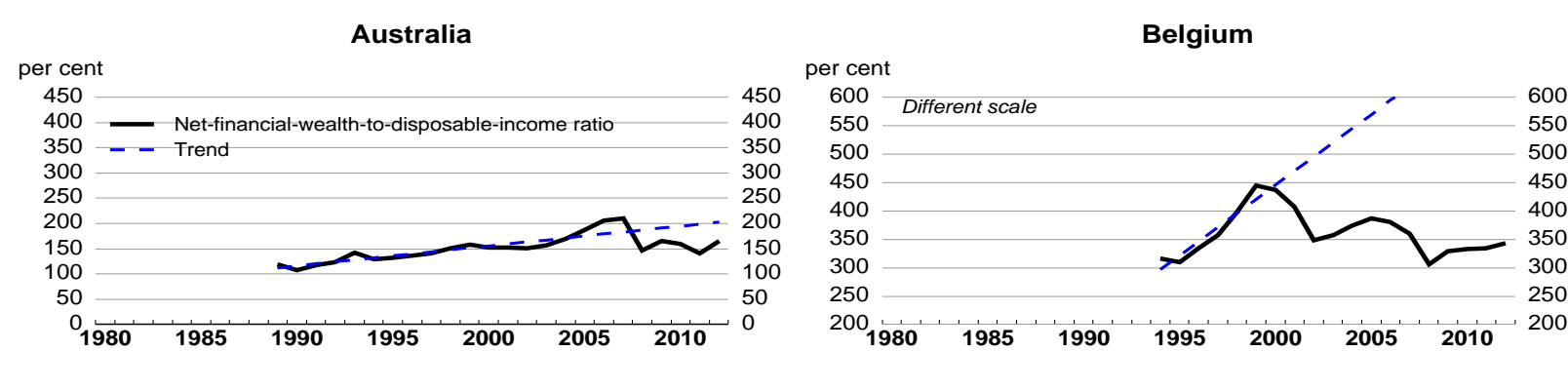

Greece
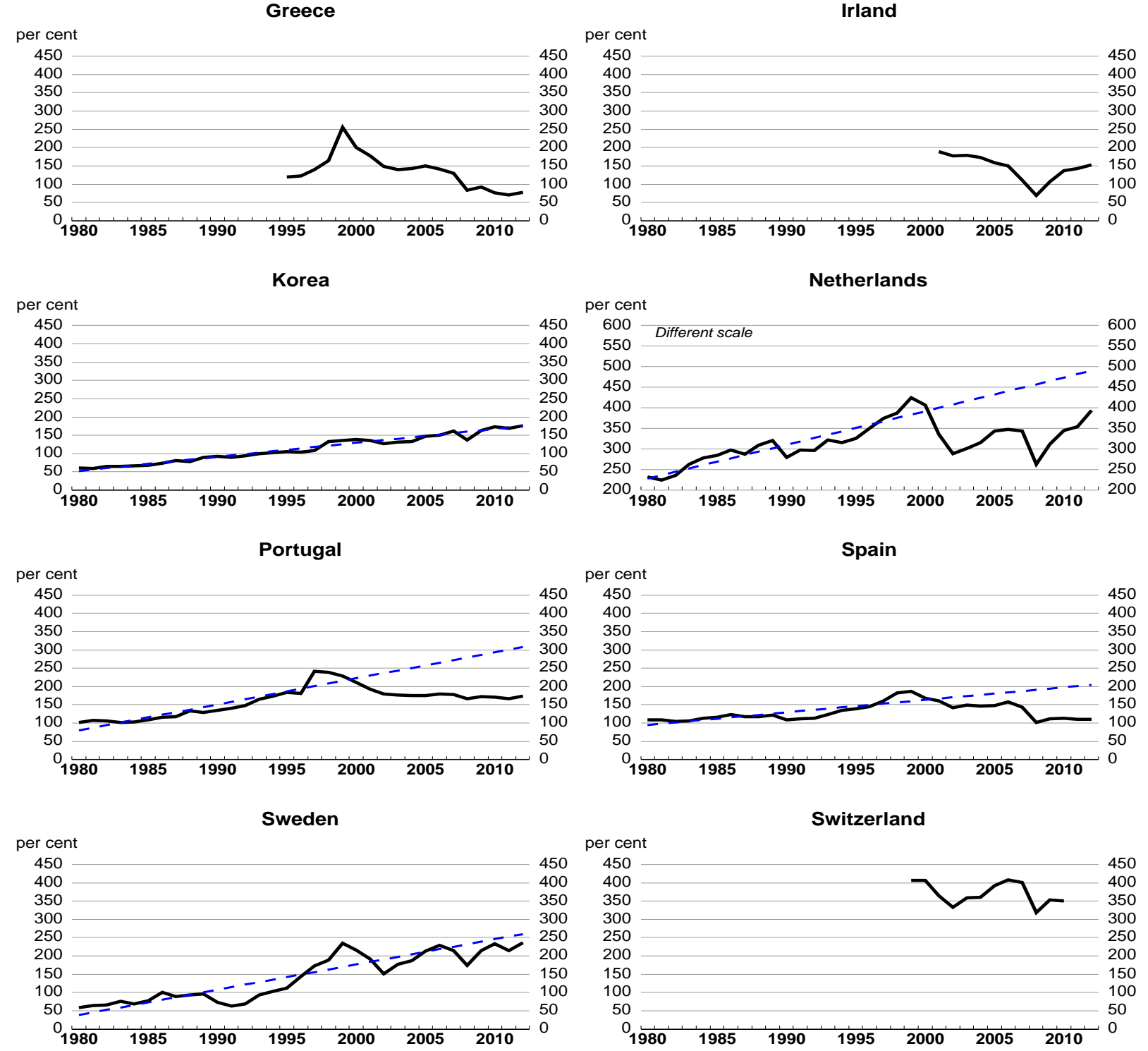

Note: Trend is OLS trend ratio computed over 1980 to 2000 if data are available, otherwise from the first year available to year 2000.

Source: OECD national accounts, national statistical offices, national central banks, ECB, Eurostat, and OECD Economic Outlook database no. 93. 
Figure 4. Gross debt over net worth of households
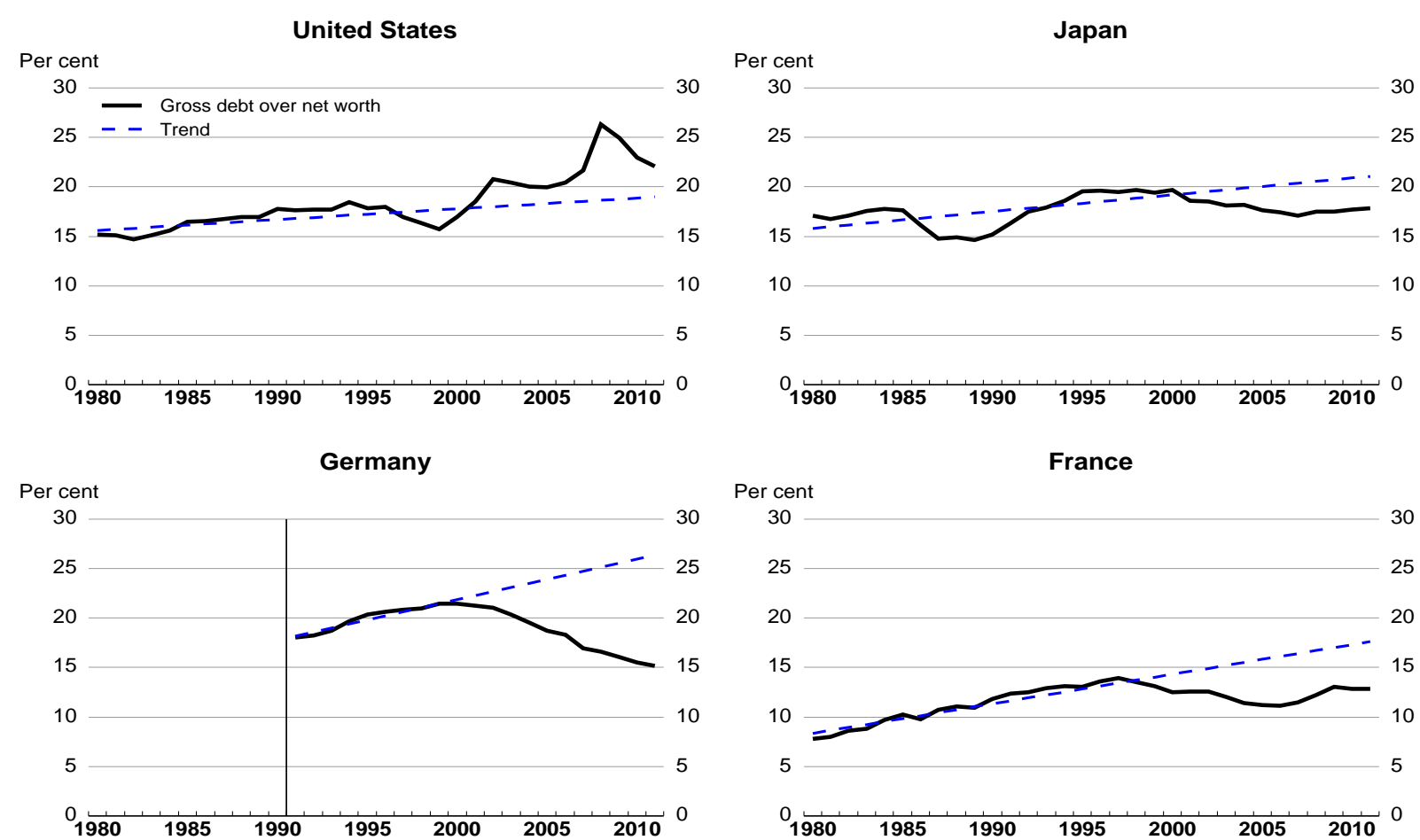

Per cent
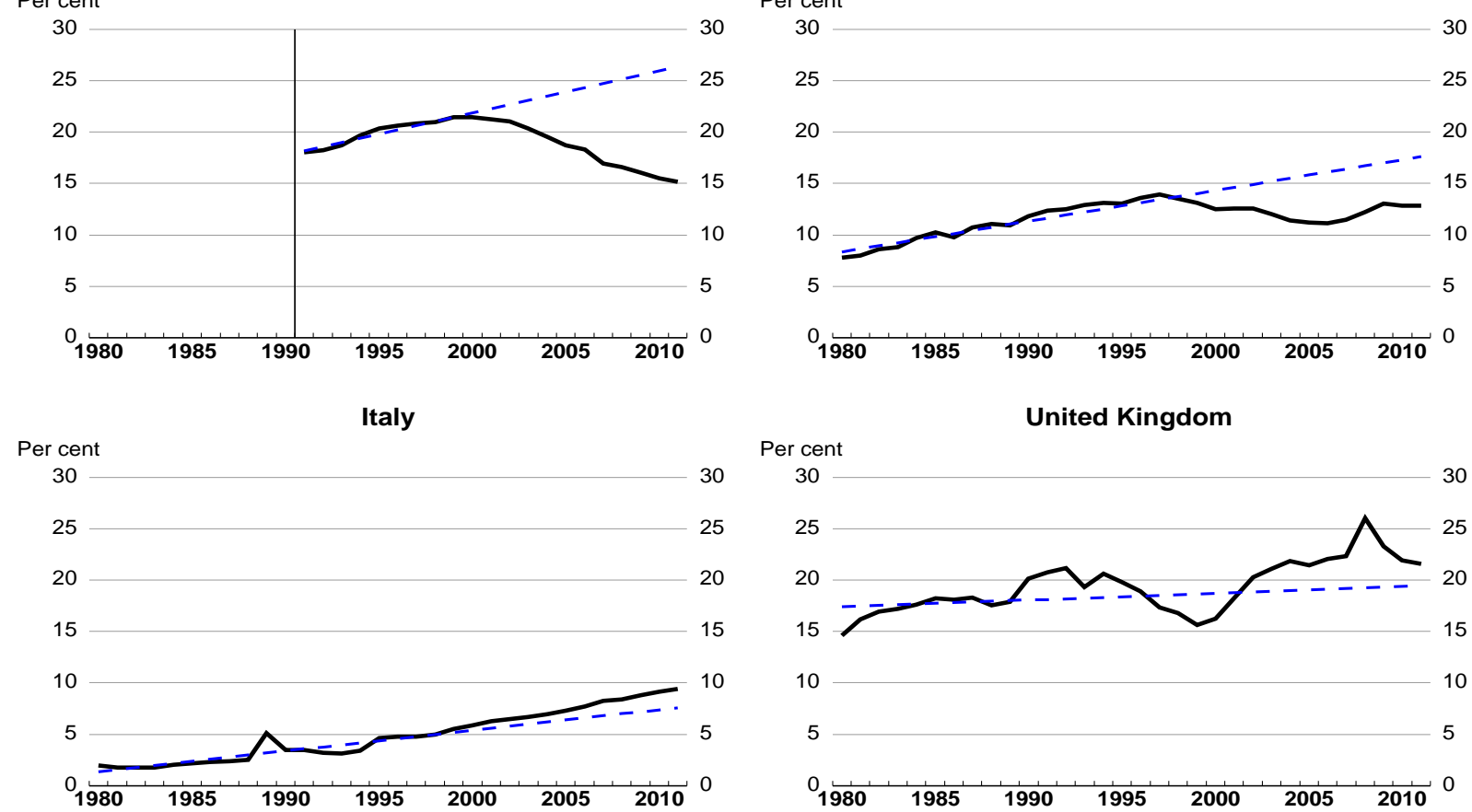

United Kingdom

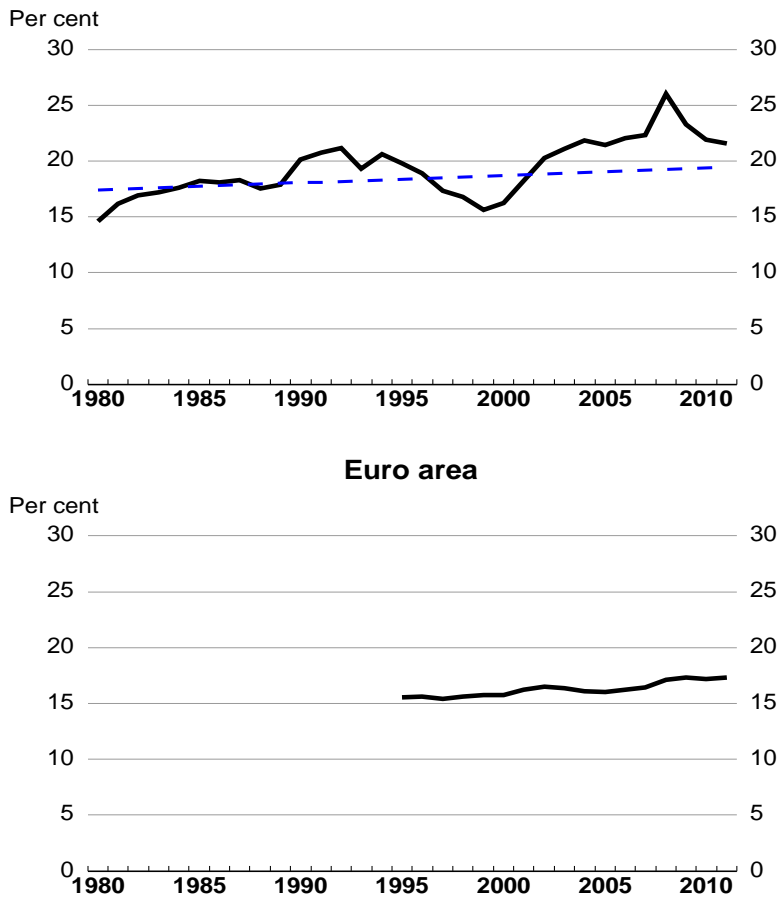

Note: Trend is OLS trend ratio computed over 1980 to 2000 if data are available, otherwise from the first year available to year 2000.

Source: OECD national accounts, national statistical offices, national central banks, ECB, Eurostat, and OECD Economic Outlook database no. 93. 
Figure 4. Gross debt over net worth of households (cont.)
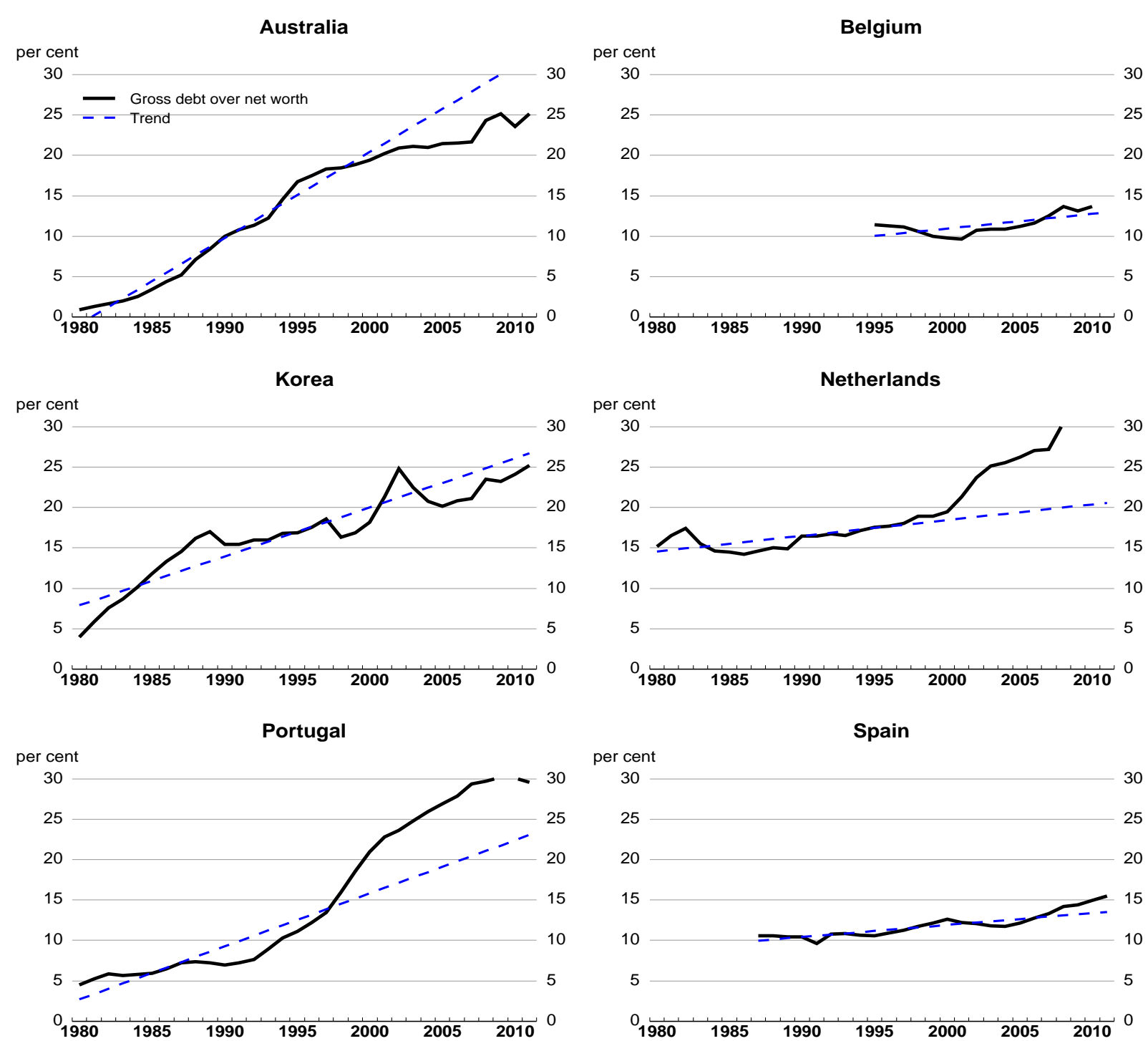

per cent

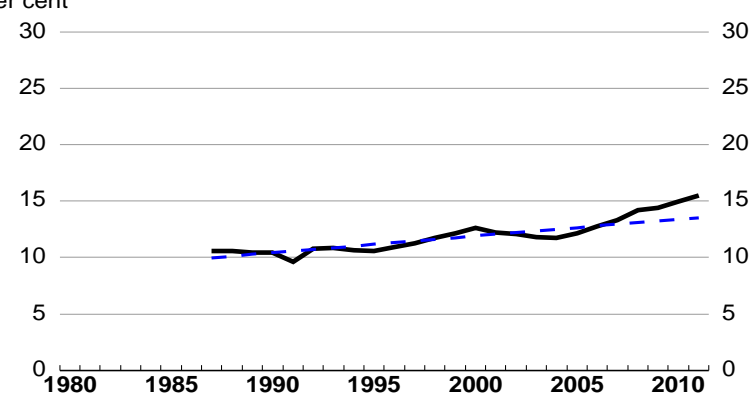

Sweden

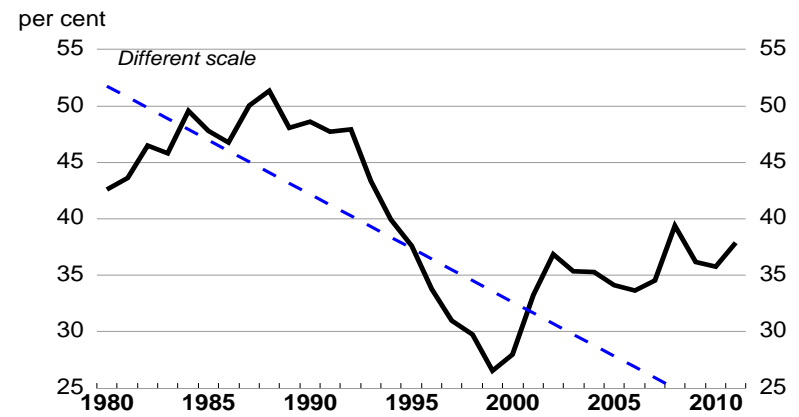

Switzerland

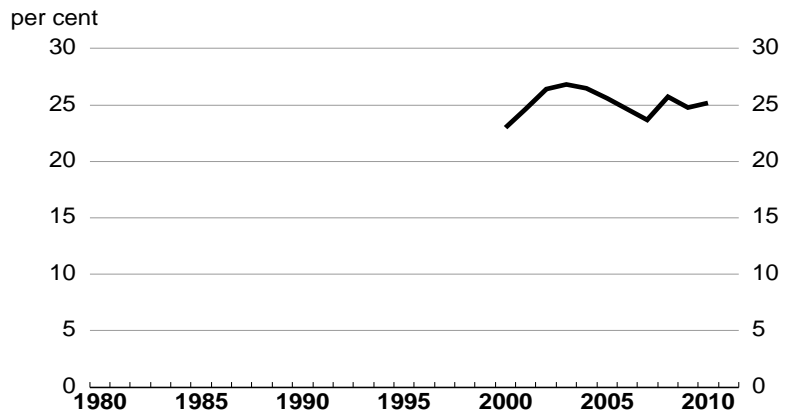

Note: Trend is OLS trend ratio computed over 1980 to 2000 if data are available, otherwise from the first year available to year 2000.

Source: OECD national accounts, national statistical offices, national central banks, ECB, Eurostat, and OECD Economic Outlook database no. 93. 
Figure 5. Ratio of debt to gross operating surplus for non-financial corporations
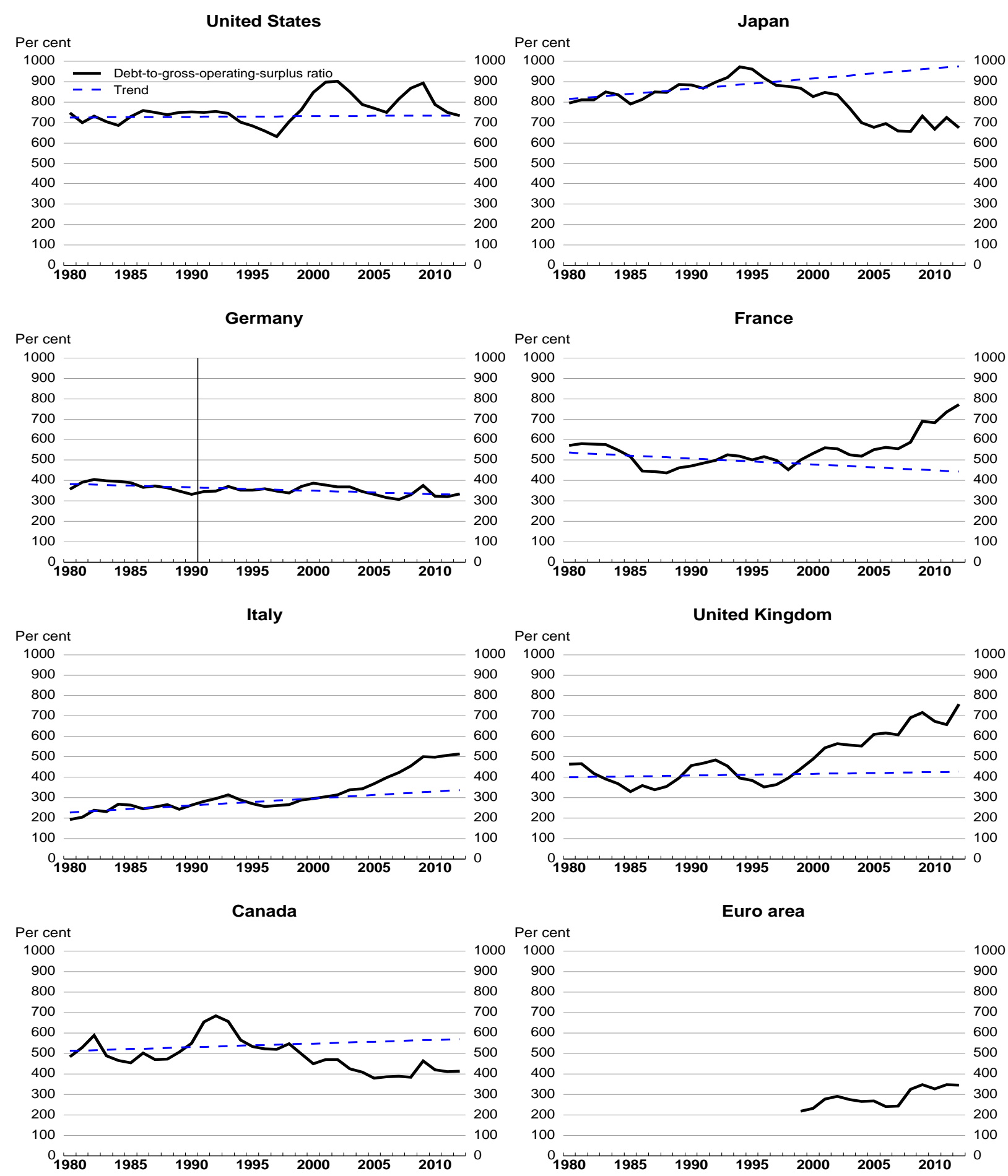

Note: Debt is calculated as total liabilities minus shares and other equities minus financial derivatives. Trend is OLS trend ratio computed over 1980 to 2000 if data are available, otherwise from the first year available to year 2000 .

Source: OECD national accounts, national statistical offices, national central banks, ECB, Eurostat, and OECD Economic Outlook database no. 93. 
Figure 5. Ratio of debt to gross operating surplus for non-financial corporations (cont.)
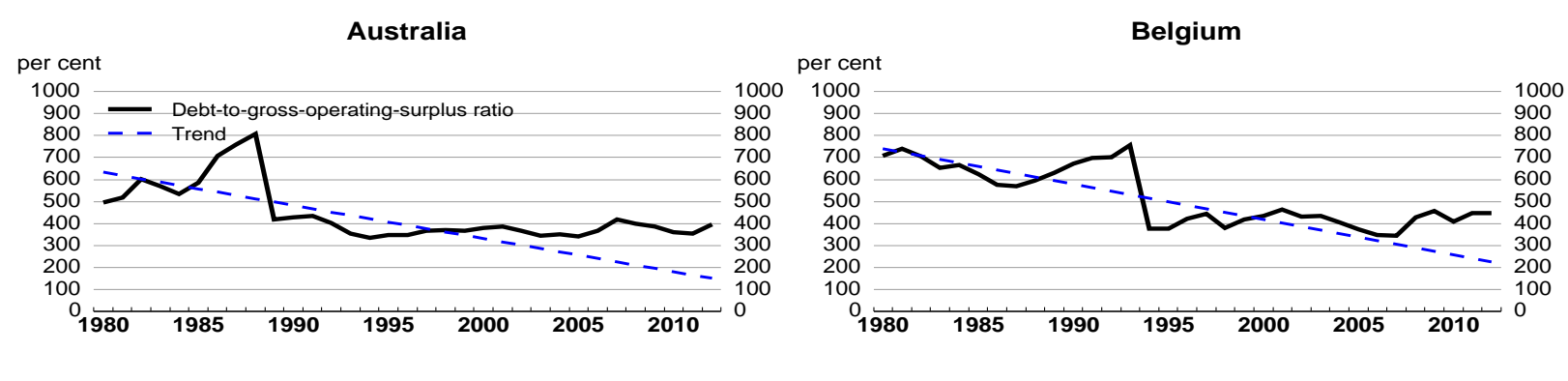

Greece

Irland
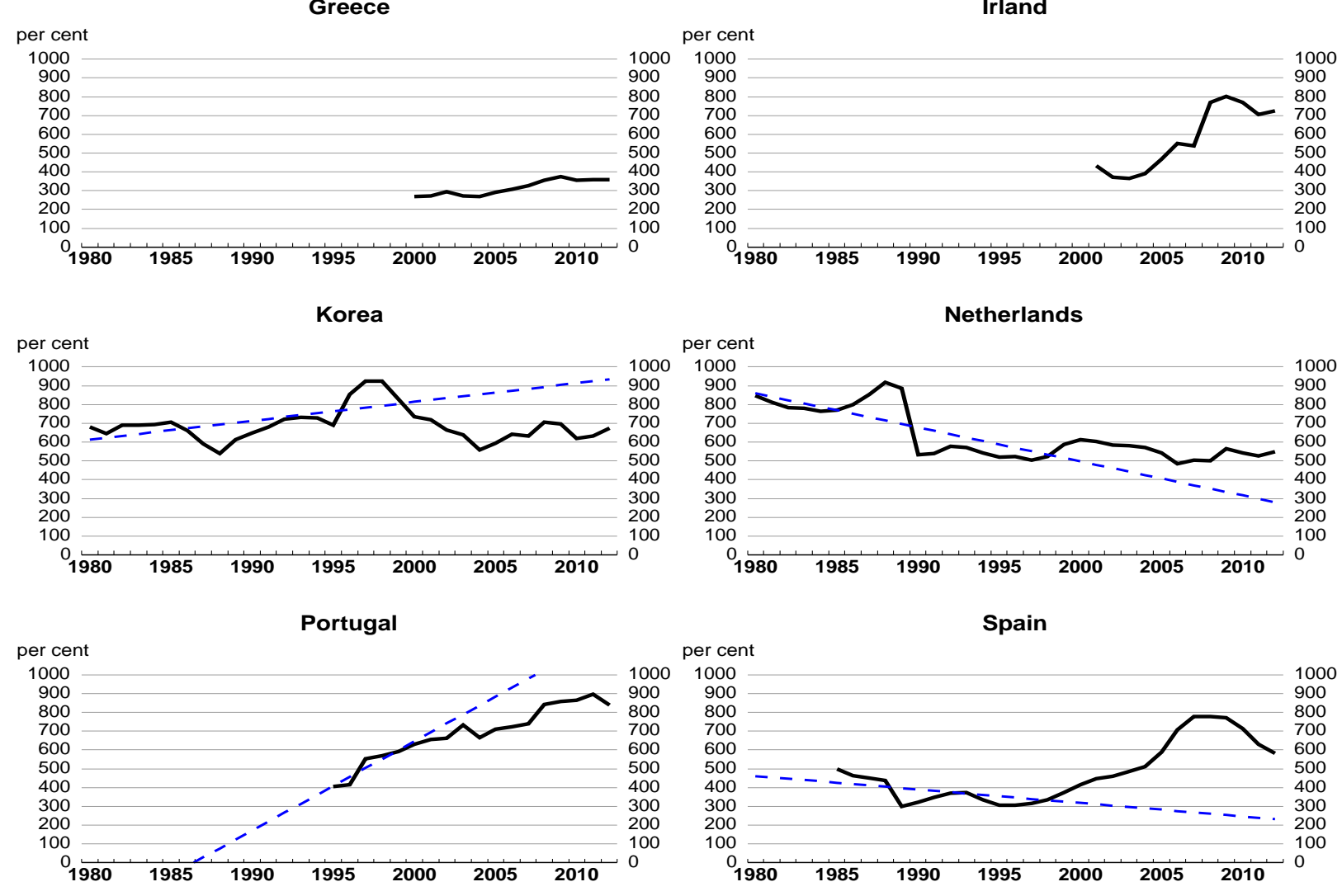

Sweden

Switzerland
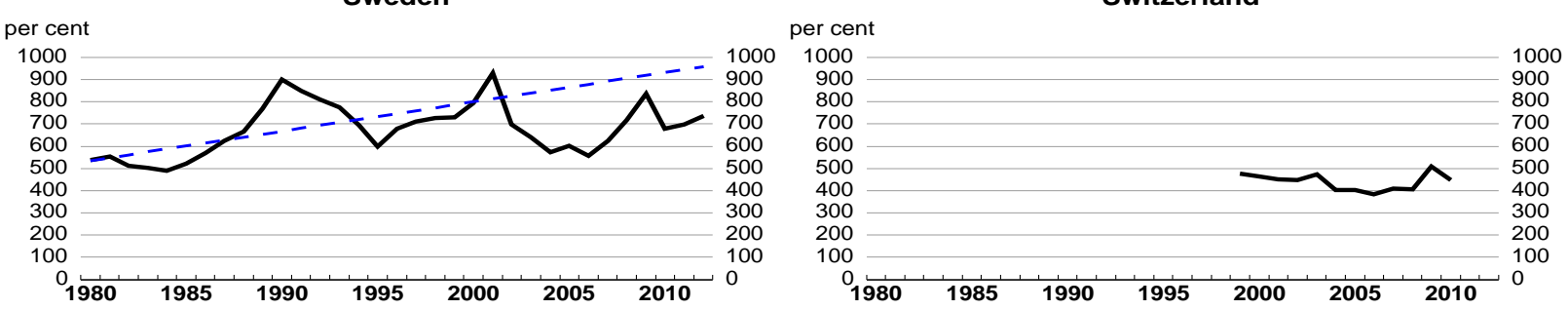

Note: Debt is calculated as total liabilities minus shares and other equities minus financial derivatives. Trend is OLS trend ratio computed over 1980 to 2000 if data are available, otherwise from the first year available to year 2000 .

Source: OECD national accounts, national statistical offices, national central banks, ECB, Eurostat, and OECD Economic Outlook database no. 93. 
Figure 6. Debt-to-equity ratios of non-financial companies

United States
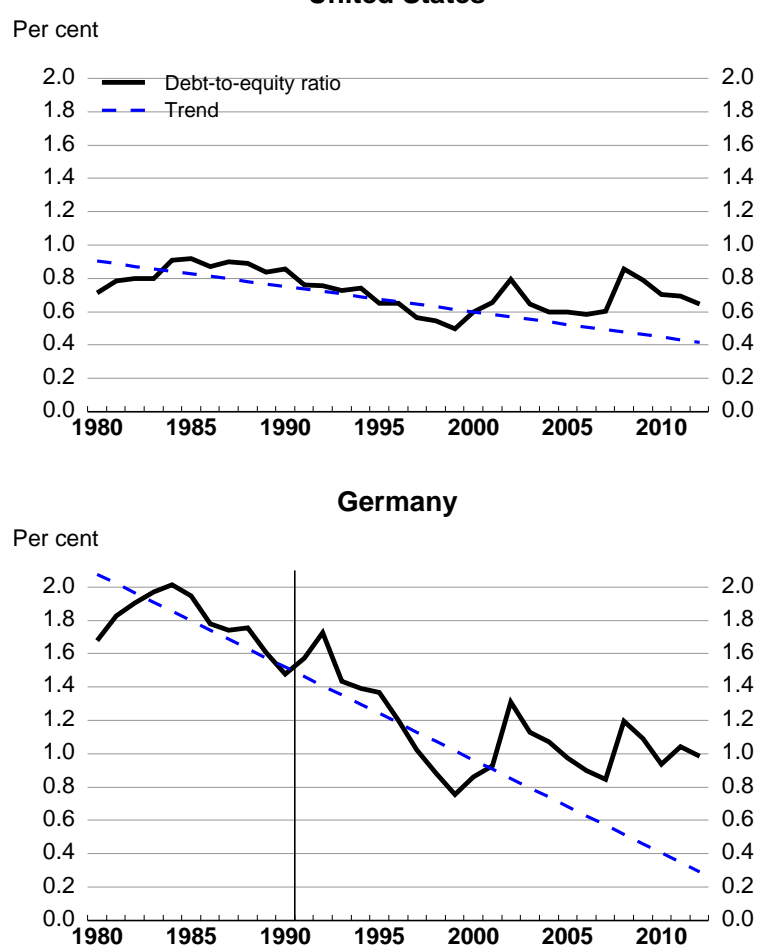

Italy

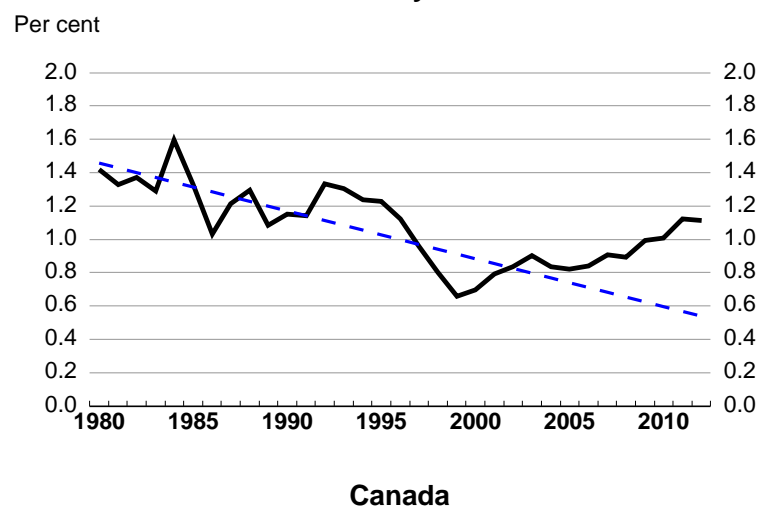

Per cent

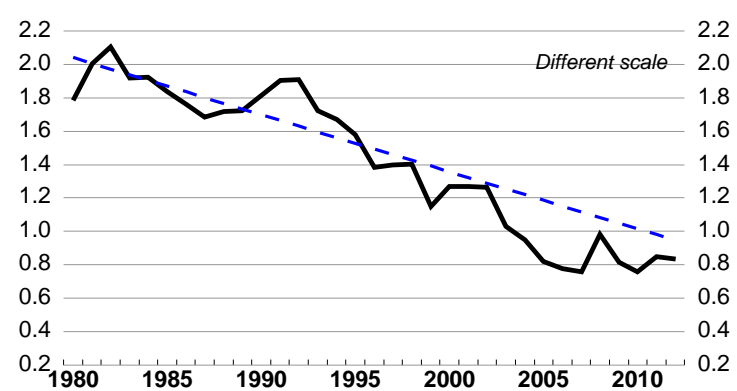

Japan

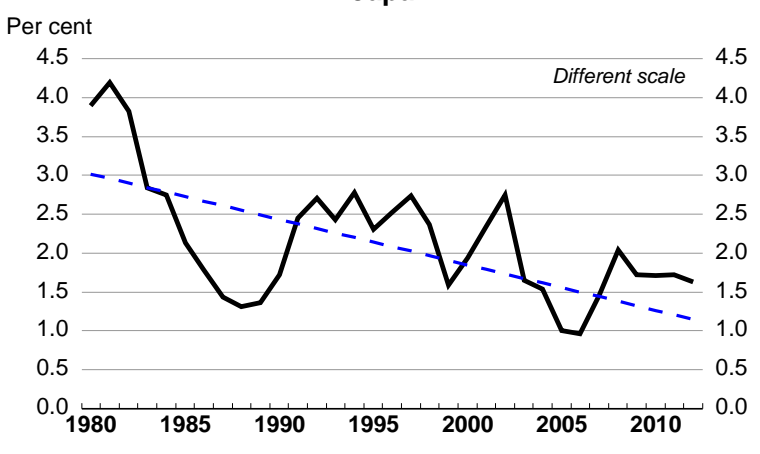

France

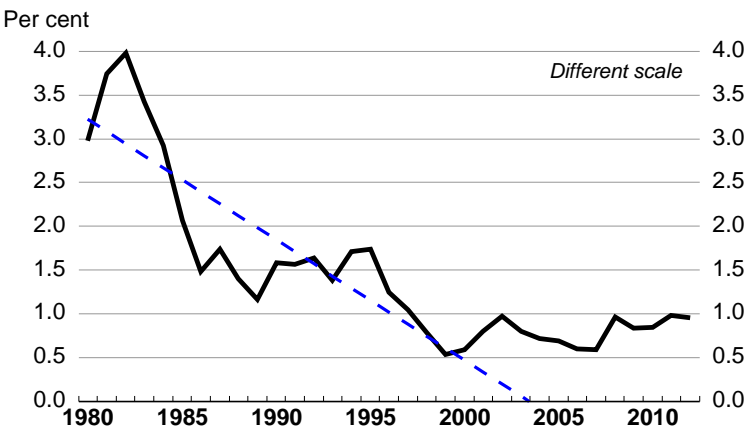

United Kingdom

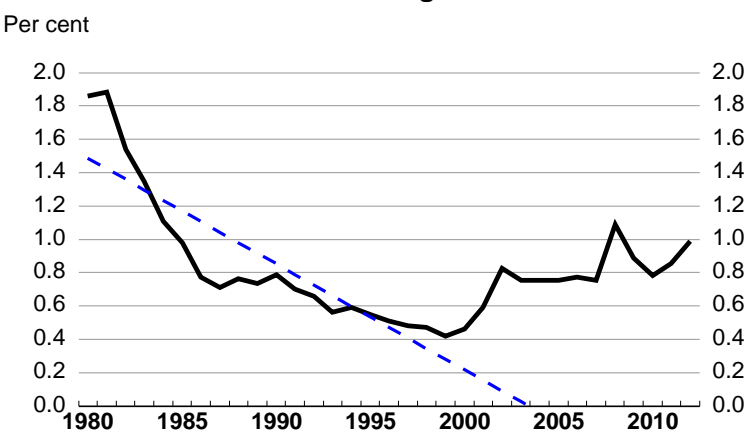

Euro area

Per cent

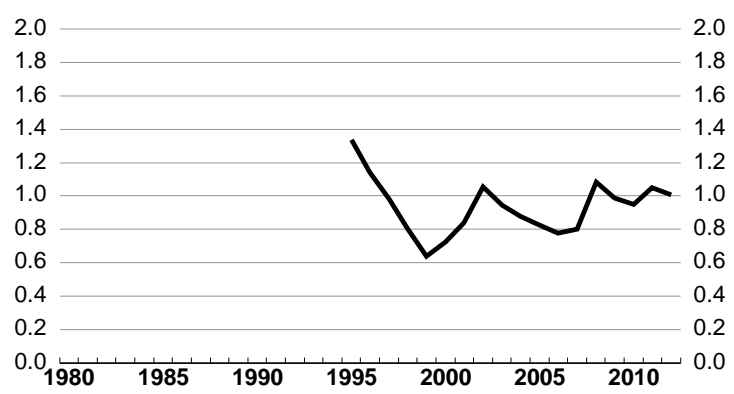

Note: Debt is calculated as total liabilities minus shares and other equities minus financial derivatives. Trend is OLS trend ratio computed over 1980 to 2000 if data are available, otherwise from the first year available to year 2000 .

Sources: OECD national accounts, national statistical offices, national central banks, ECB and Eurostat. 
Figure 6. Debt-to-equity ratios of non-financial companies (cont.)

Australia
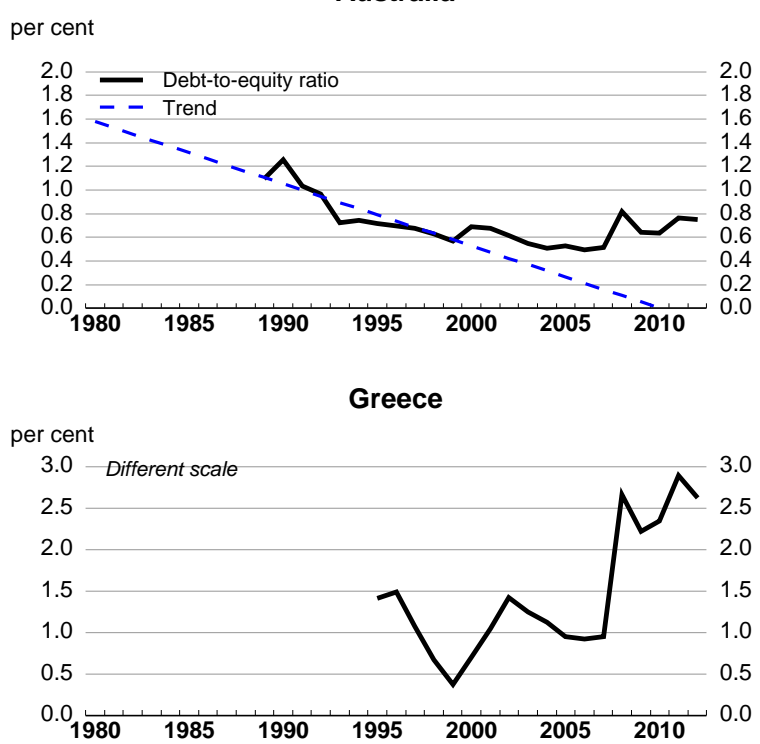

Korea

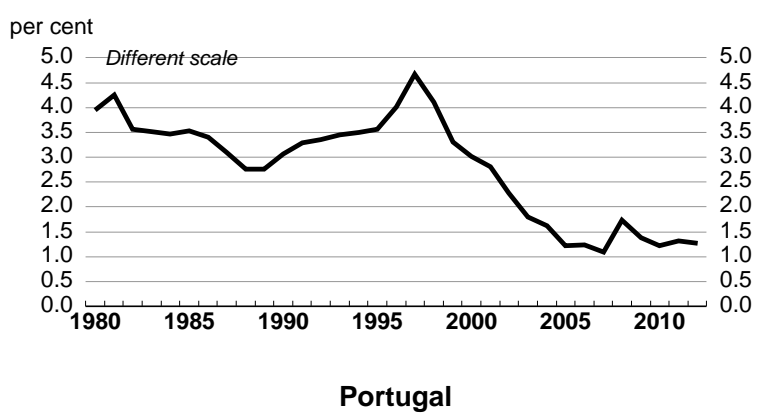

per cent

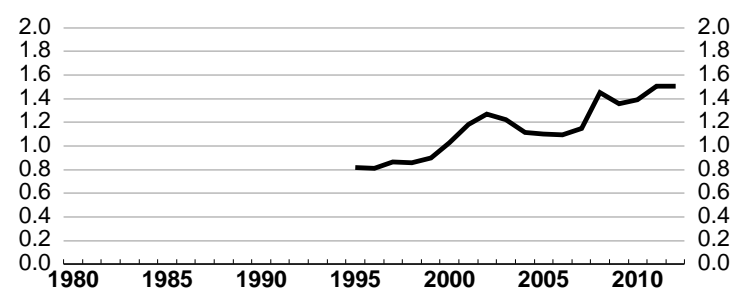

Sweden

per cent

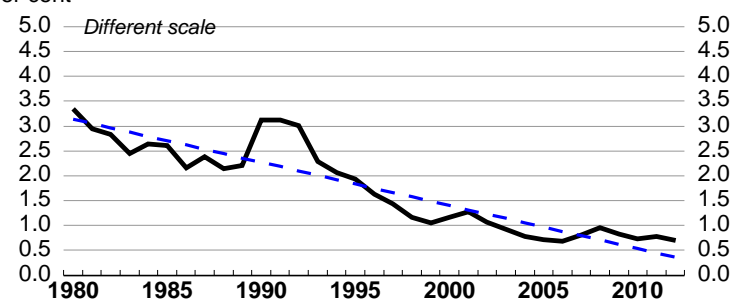

Belgium

per cent

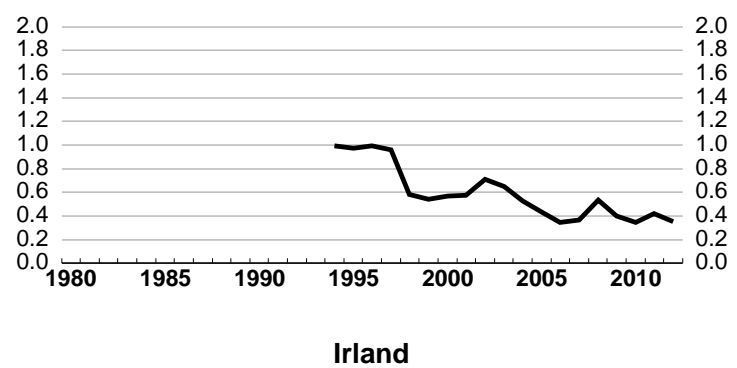

per cent

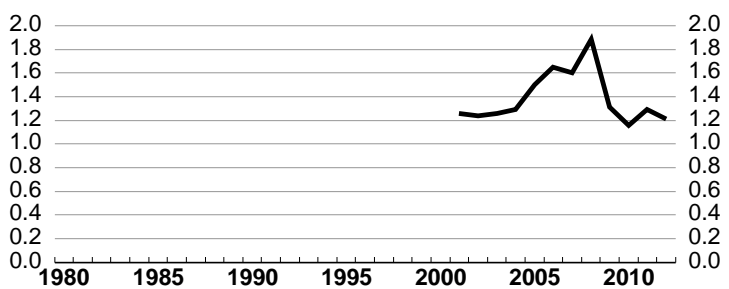

Netherlands

per cent

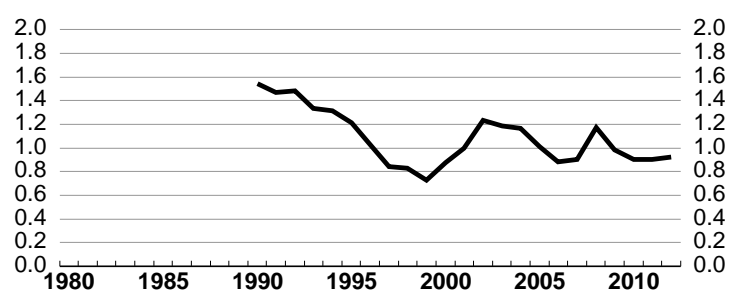

Spain

per cent

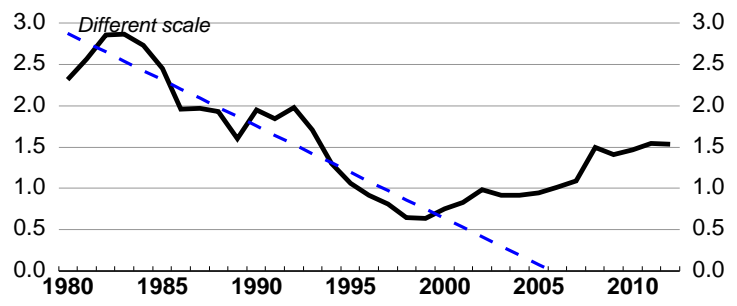

Switzerland

per cent

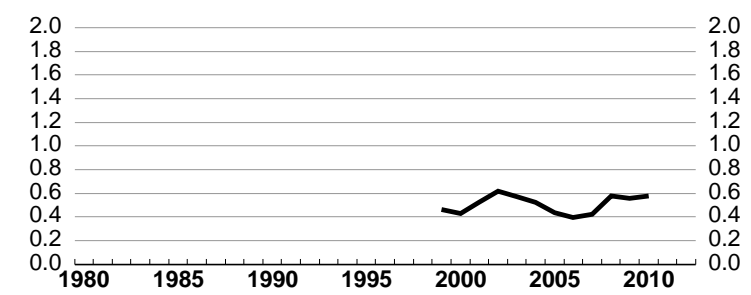

Note: Debt is calculated as total liabilities minus shares and other equities minus financial derivatives. Trend is OLS trend ratio computed over 1980 to 2000 if data are available, otherwise from the first year available to year 2000 .

Sources: OECD national accounts, national statistical offices, national central banks, ECB and Eurostat. 
Figure 7. Debt-to-GDP ratio of the financial sector
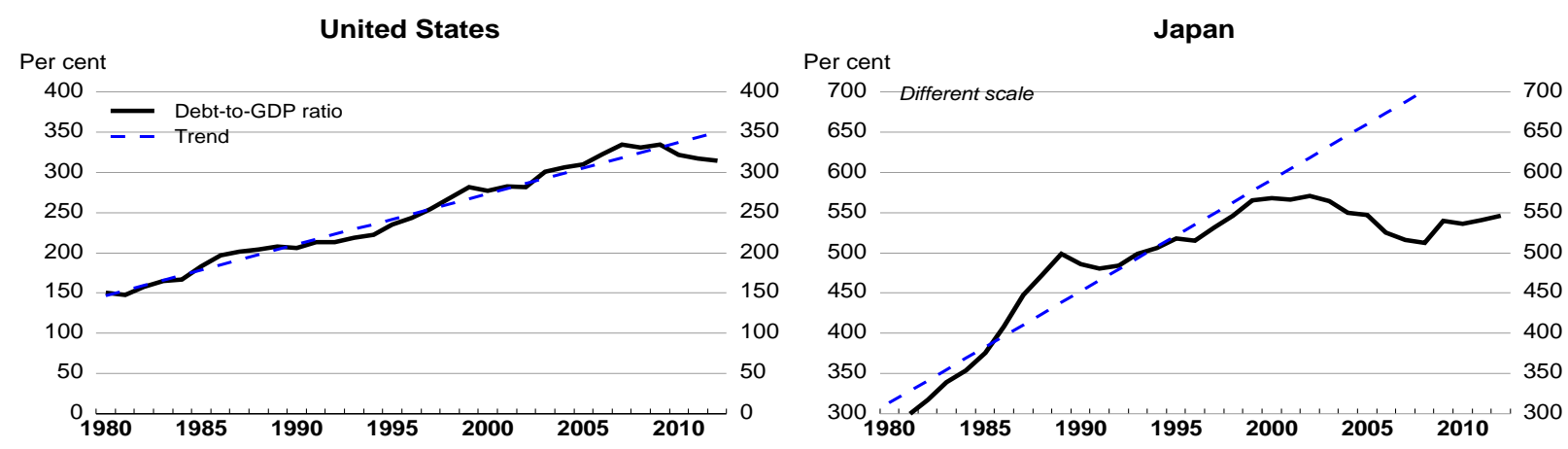

Germany
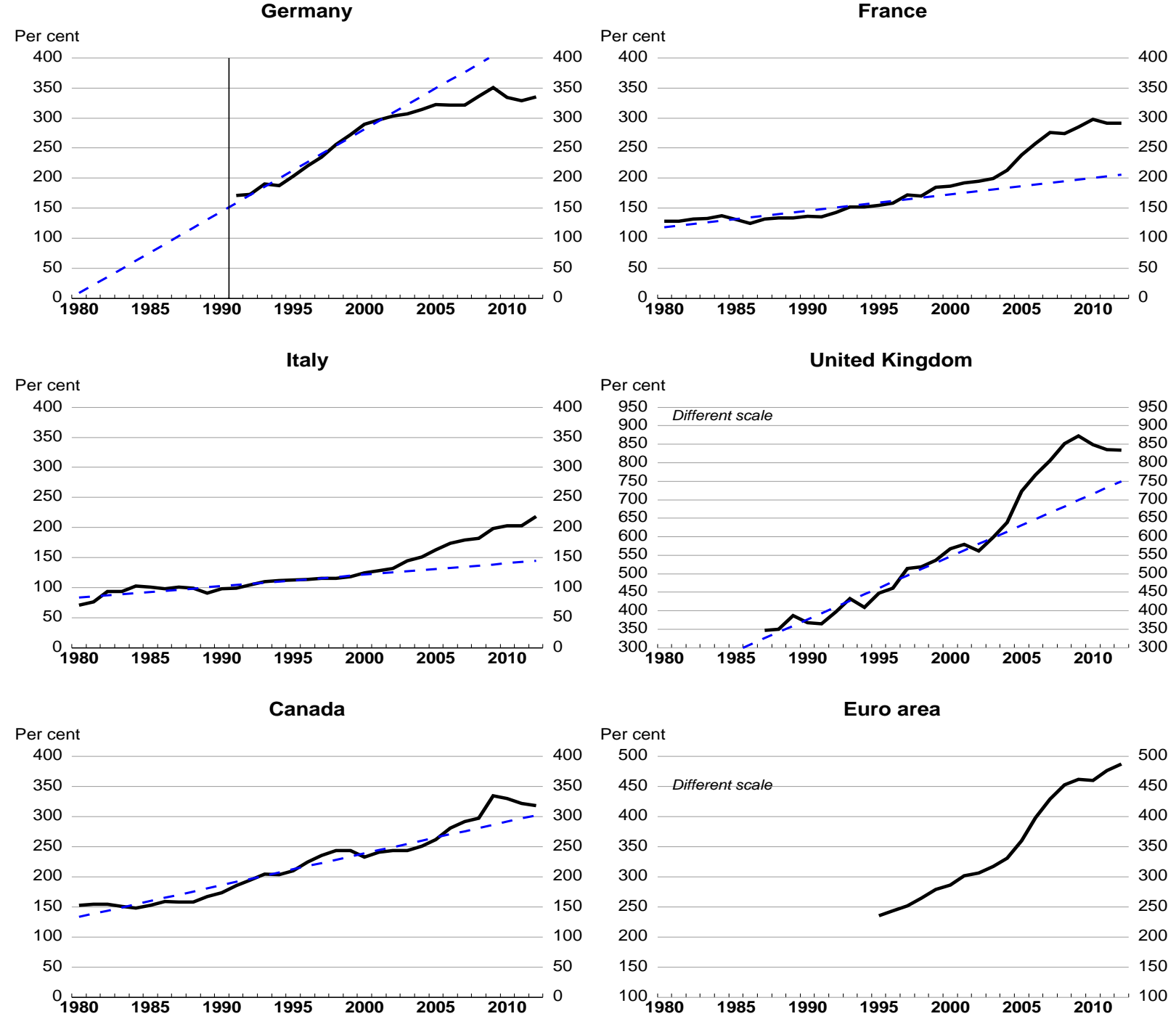

Note: Debt is calculated as total liabilities minus shares and other equities minus financial derivatives. Trend is OLS trend ratio computed over 1980 to 2000 if data are available, otherwise from the first year available to year 2000 .

Source: OECD national accounts, national statistical offices, national central banks, ECB, Eurostat, and OECD Economic Outlook database no. 93 
Figure 7. Debt-to-GDP ratio of the financial sector (cont.)
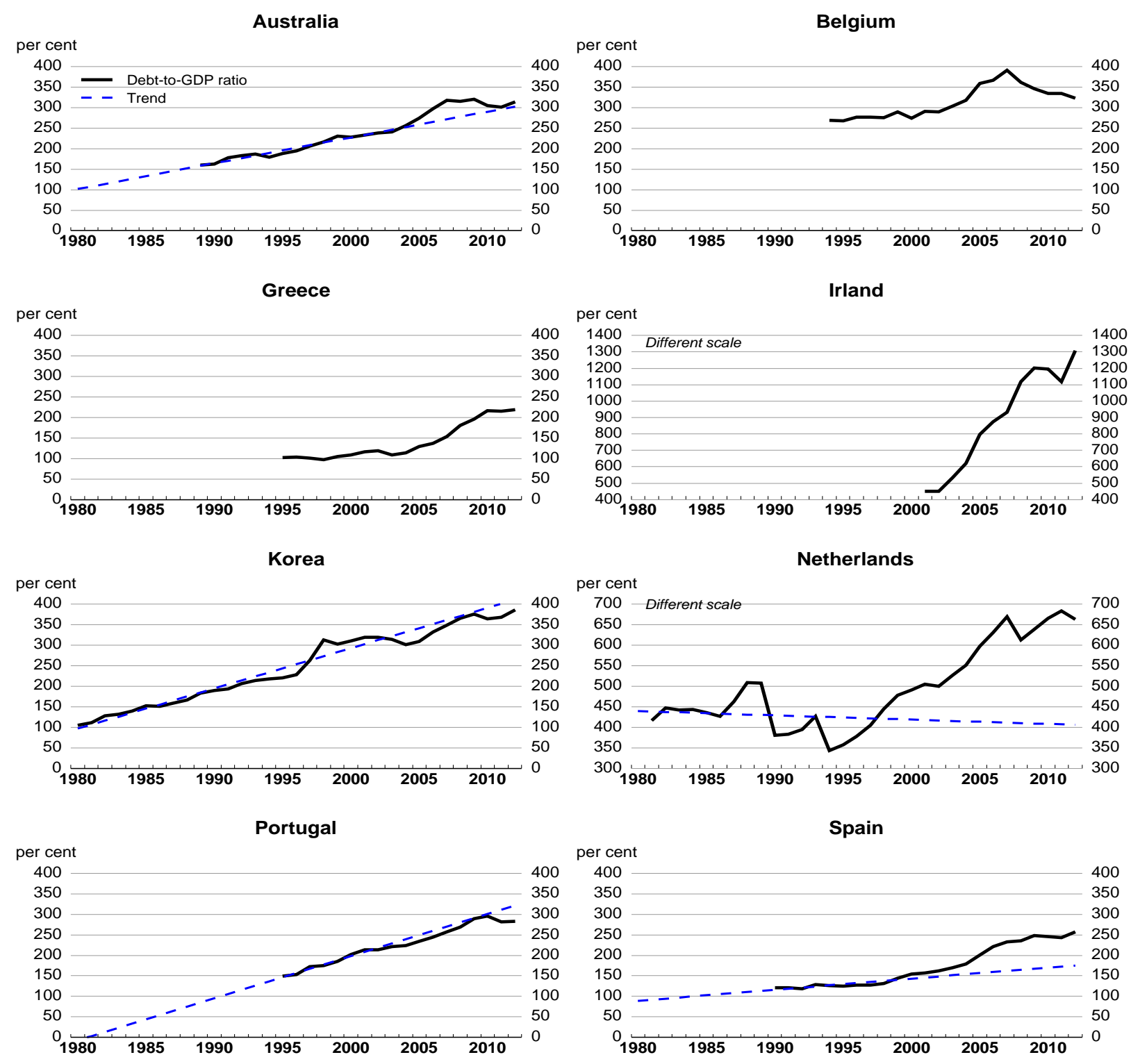

Sweden
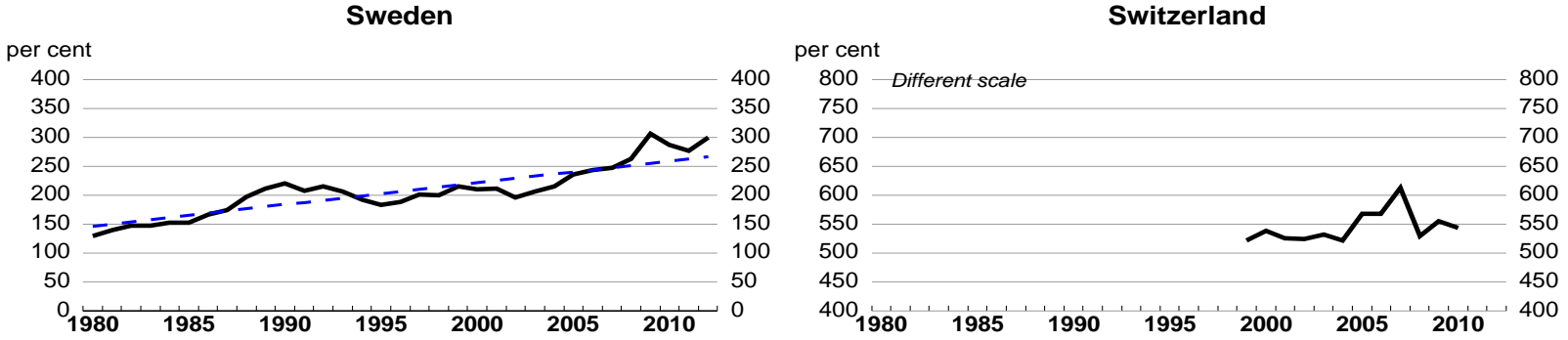

Note: Debt is calculated as total liabilities minus shares and other equities minus financial derivatives. Trend is OLS trend ratio computed over 1980 to 2000 if data are available, otherwise from the first year available to year 2000 .

Source: OECD national accounts, national statistical offices, national central banks, ECB, Eurostat, and OECD Economic Outlook database no. 93. 
Figure 8. Leverage ratio (total assets to equity) of financial corporations

United States
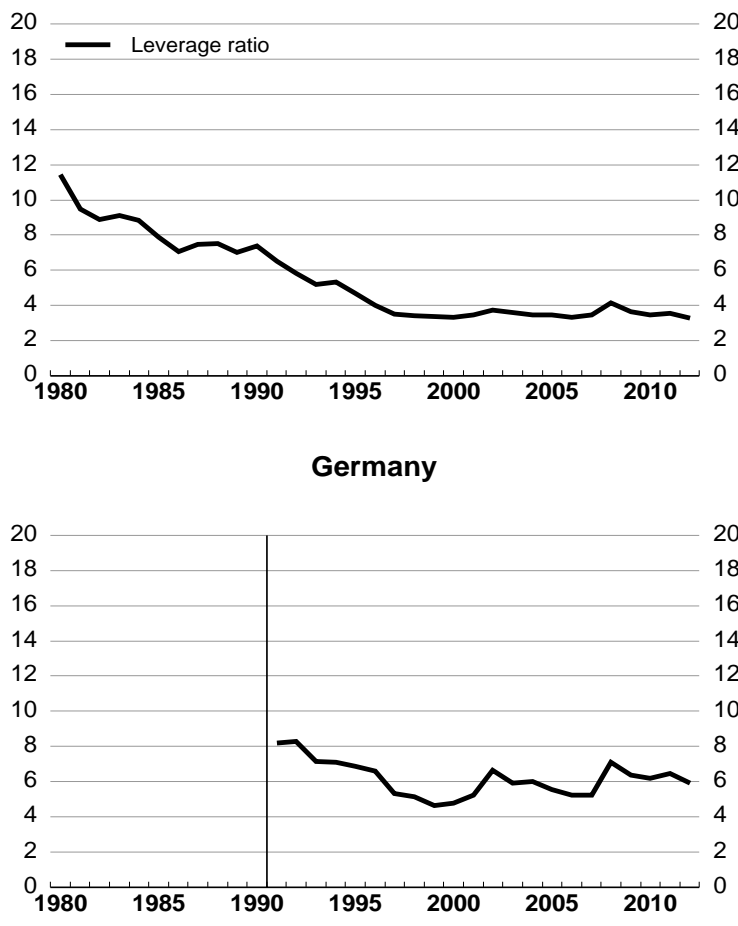

Italy
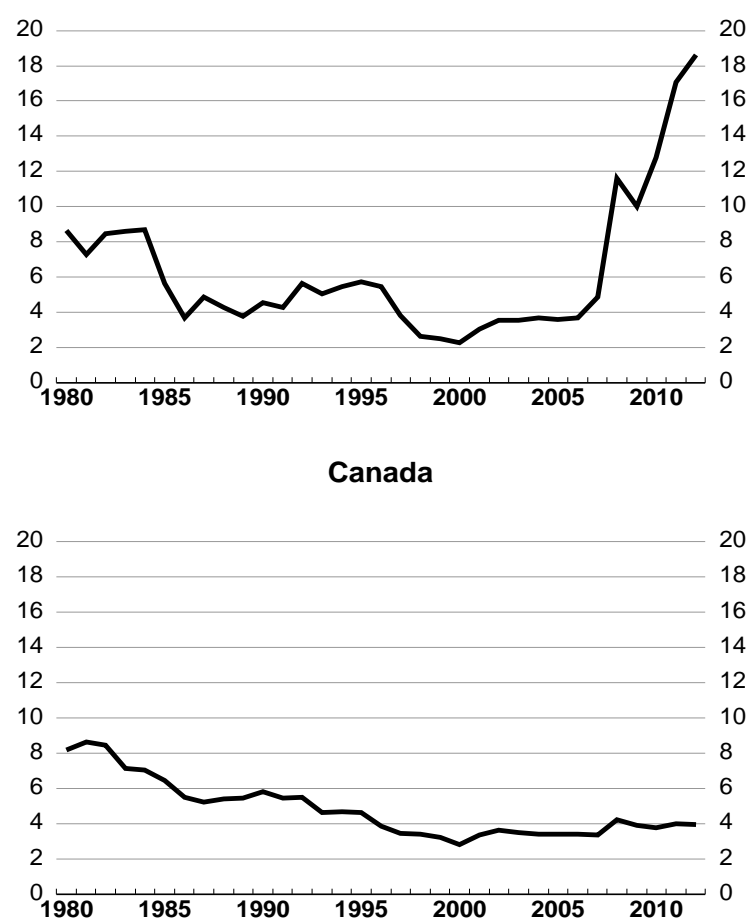

Japan
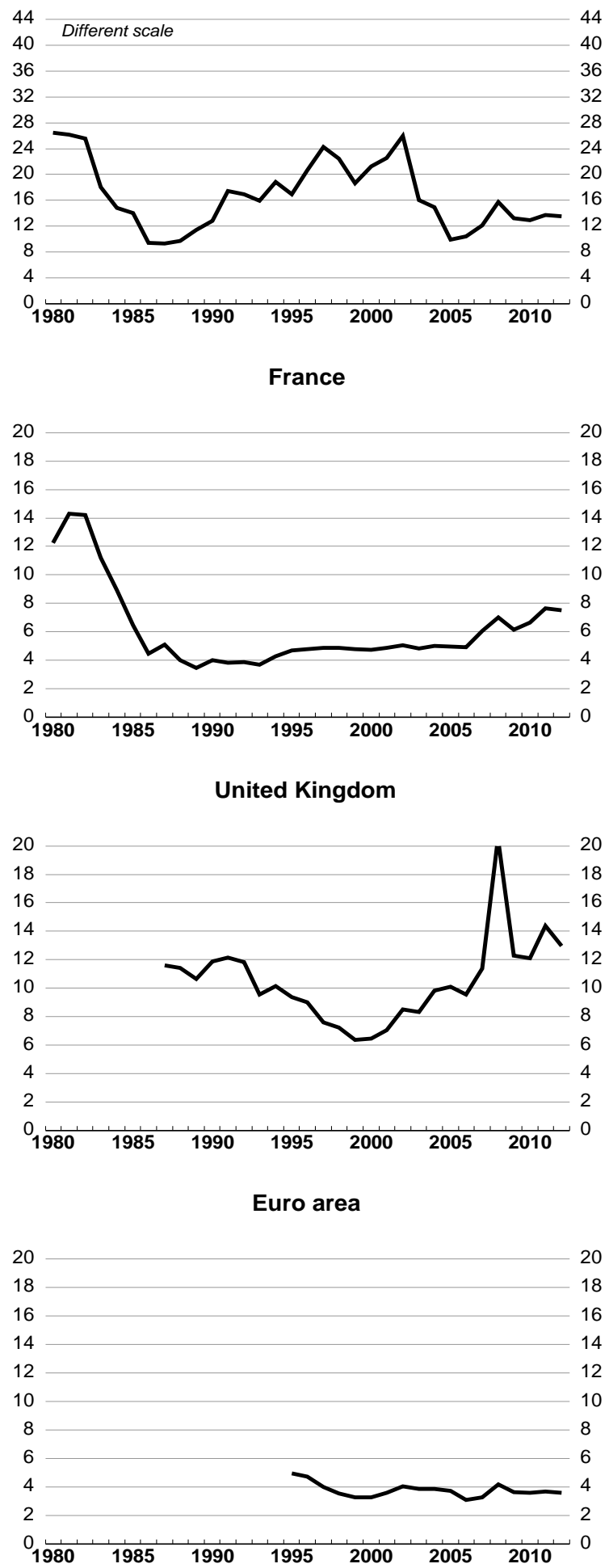

Source: OECD national accounts, national statistical offices, national central banks, ECB, Eurostat, and OECD Economic Outlook database no. 93. 
Figure 8. Leverage ratio (total assets to equity) of financial corporations (cont.)

Australia

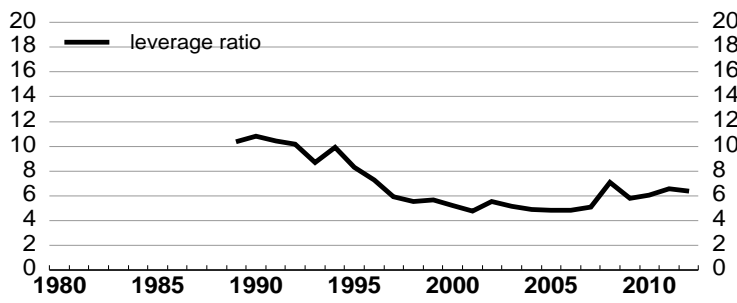

Greece

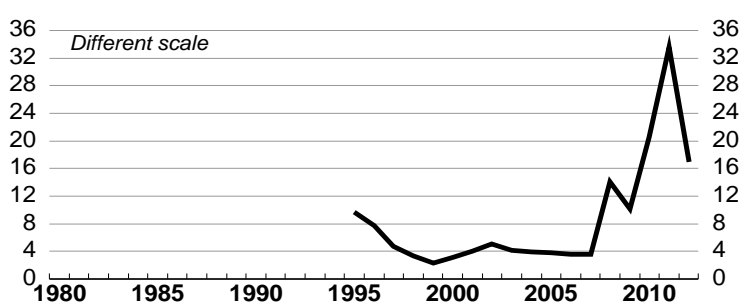

Korea
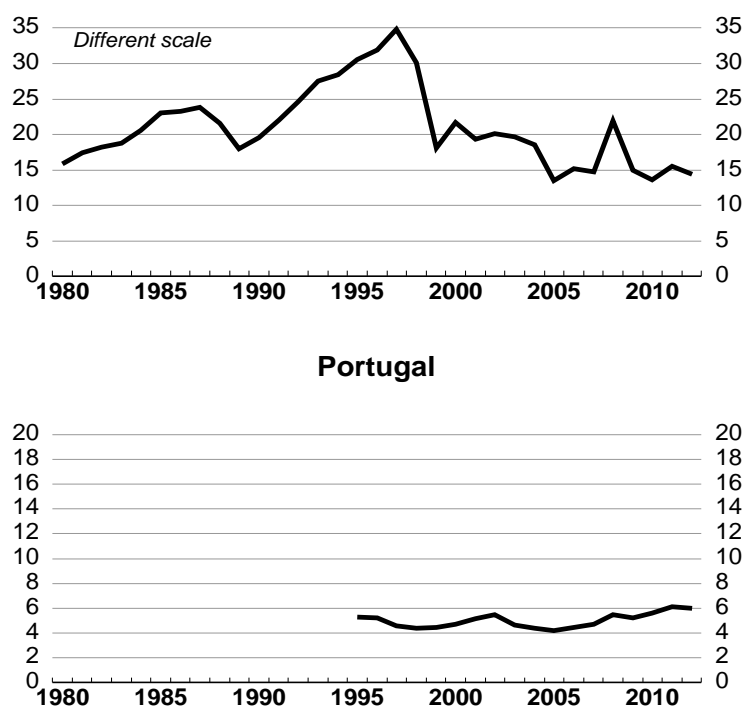

Sweden

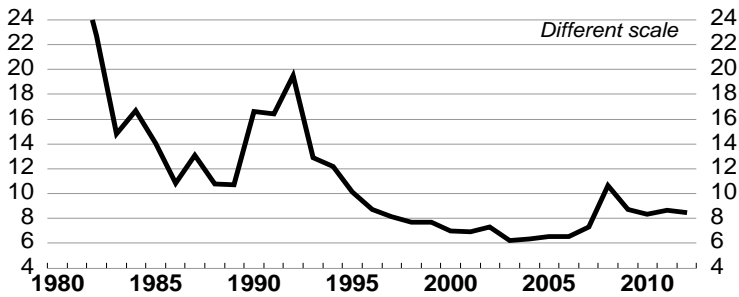

Belgium

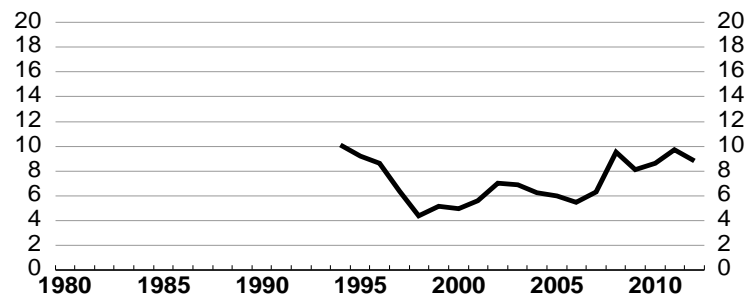

Irland

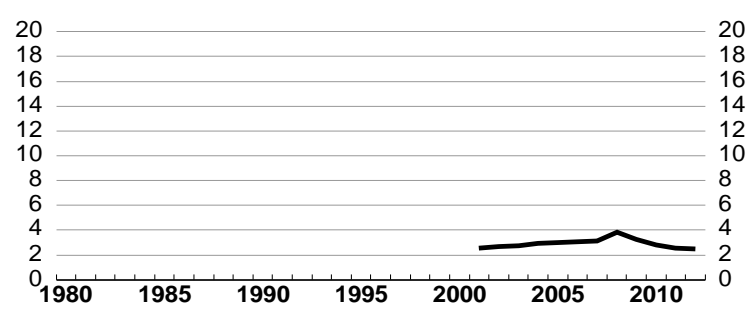

Netherlands

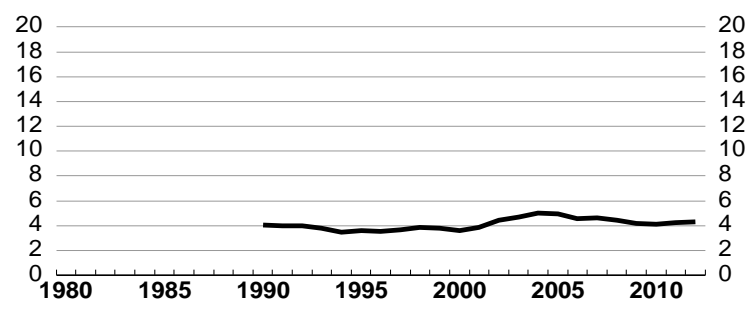

Spain

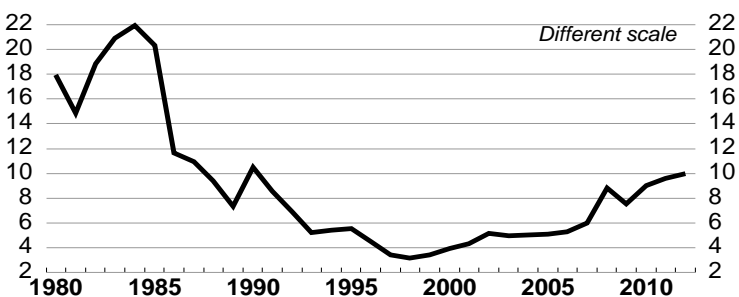

Switzerland

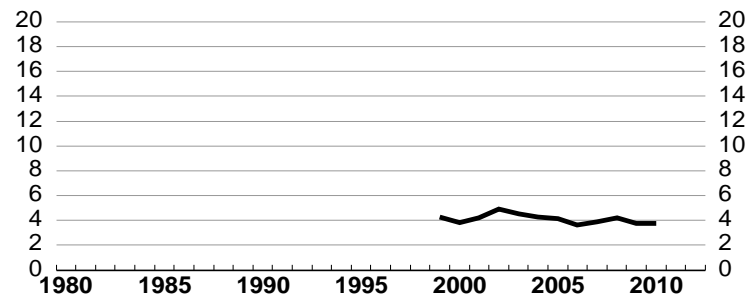

Source: OECD national accounts, national statistical offices, national central banks, ECB, Eurostat, and OECD Economic Outlook database no. 93 . 
ECO/WKP(2013)69

Figure 9. House price increases and the rise in household debt ratios are positively related

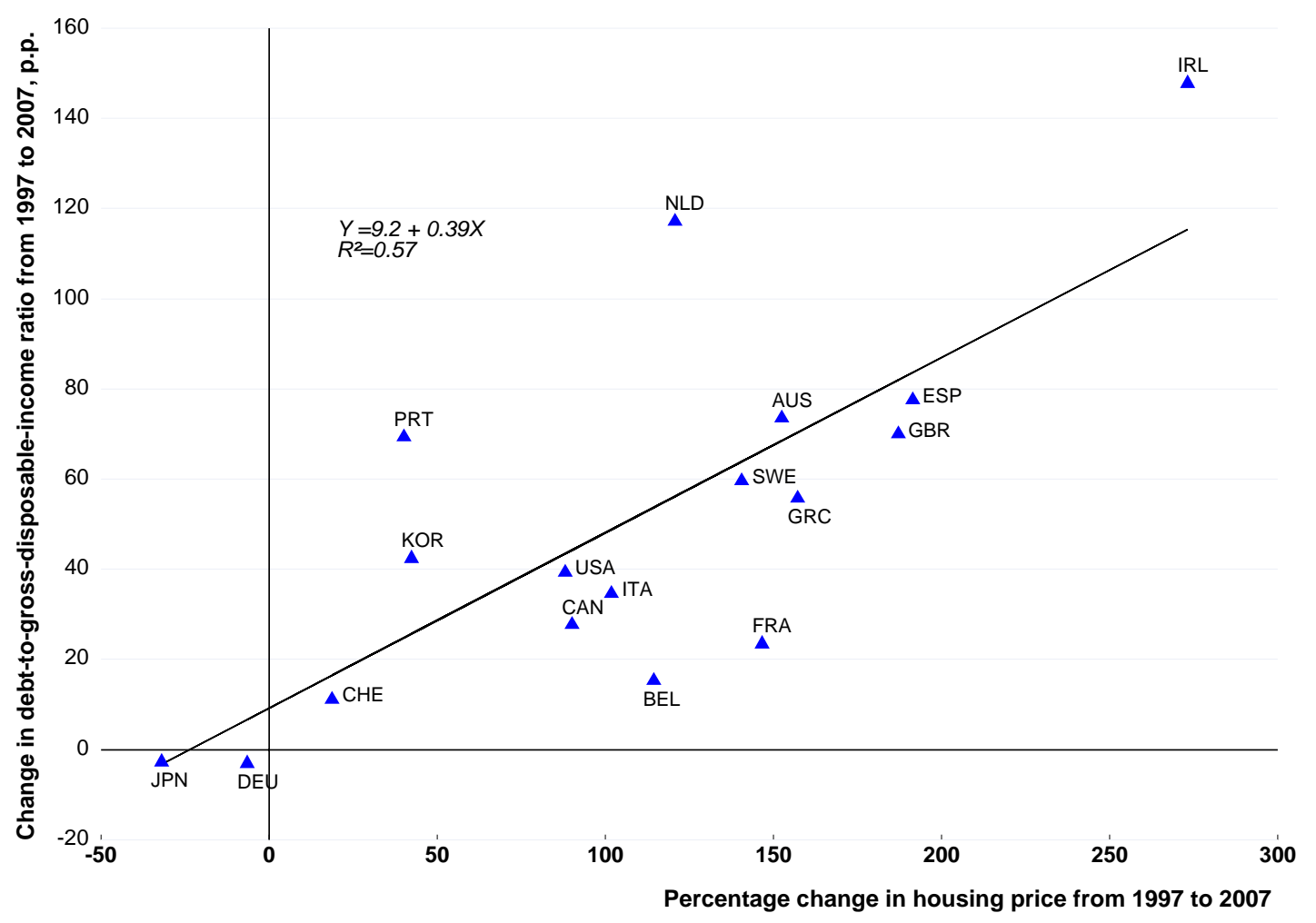

Source: OECD Economic Outlook no. 93 database. 
Figure 10. Saving ratio over 1980-2012

Household-saving-to-net-disposable-income ratio

United States
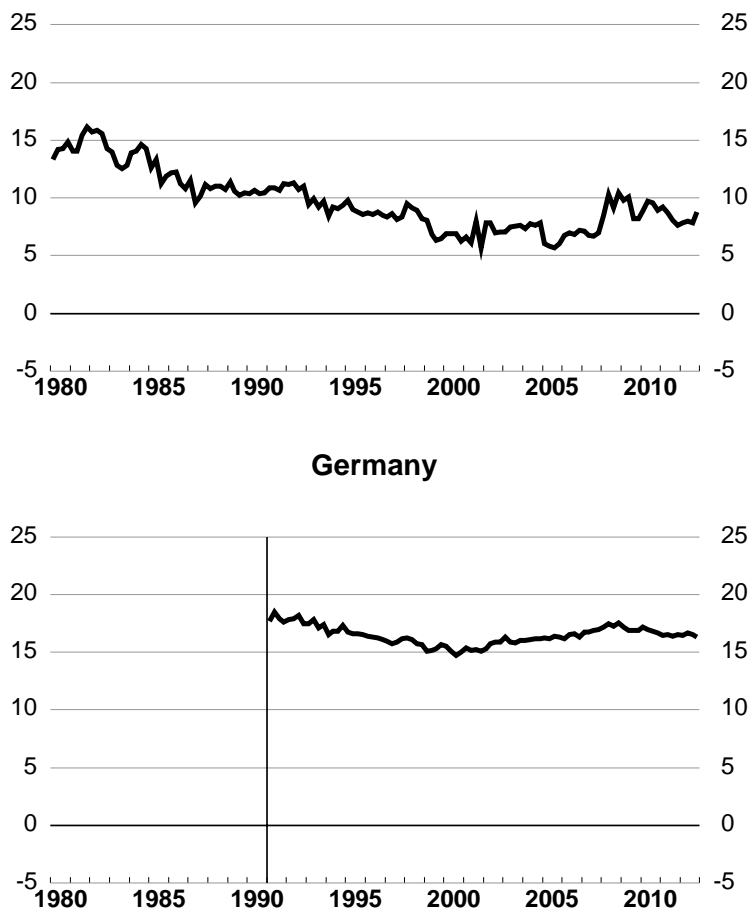

Italy

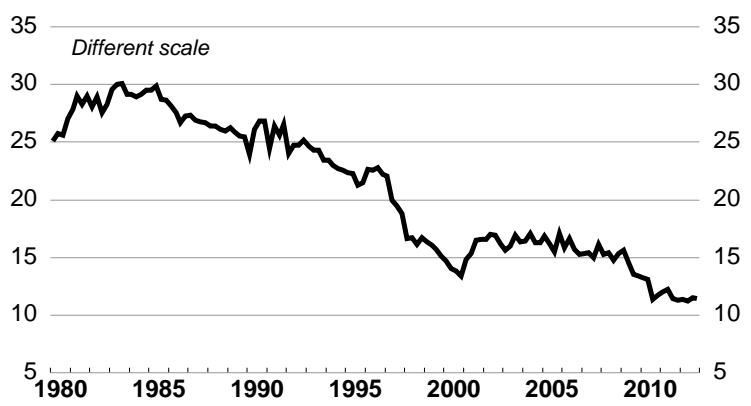

Canada

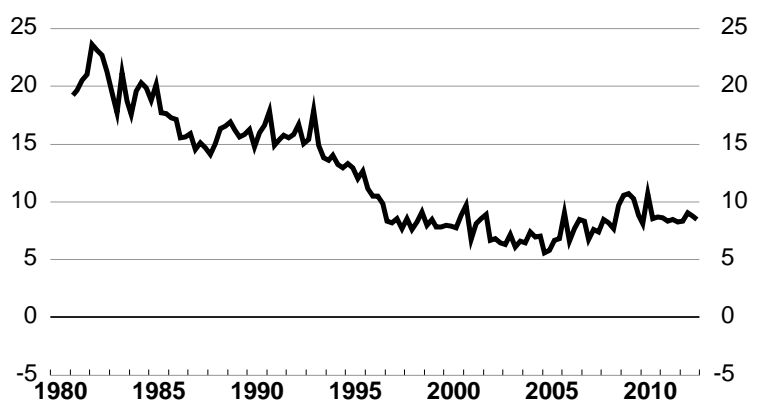

Japan
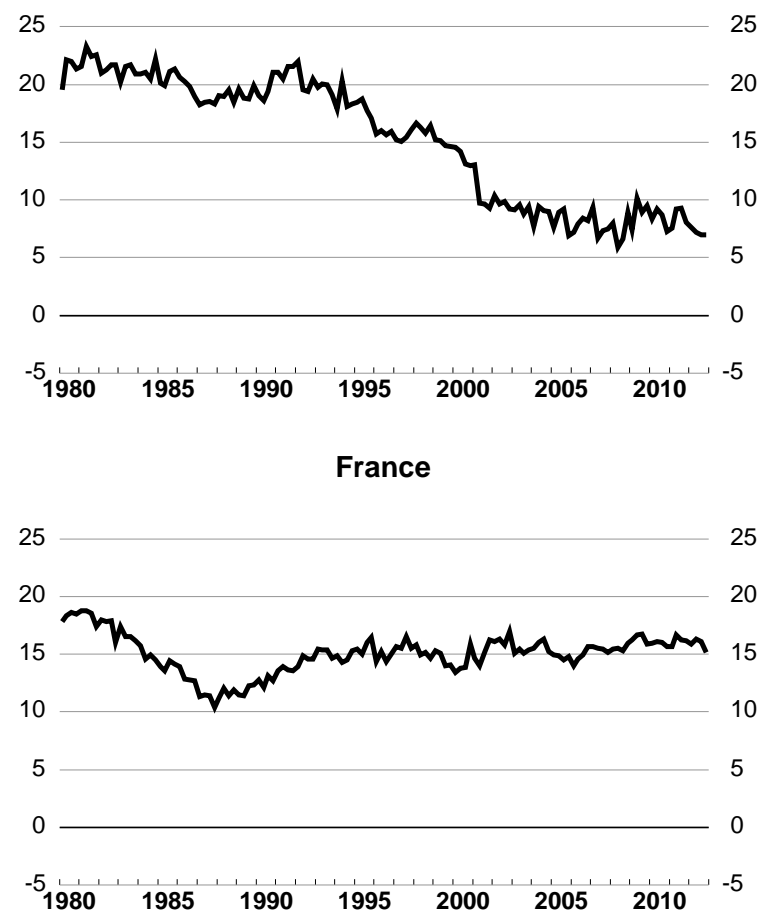

United Kingdom

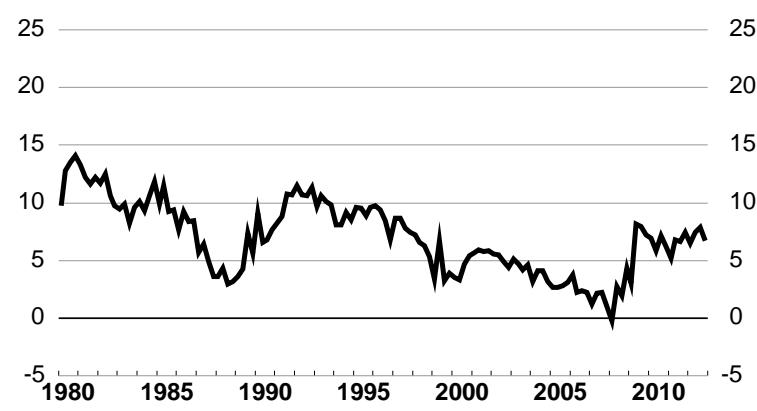

Euro area

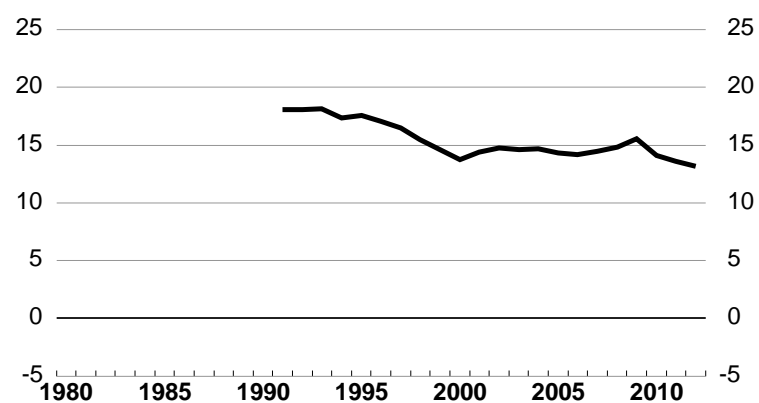

Source: OECD Economic Outlook database no. 93. 
Figure 10. Saving ratio over 1980-2012 (cont.)

Household-saving-to-net-disposable-income ratio

Australia

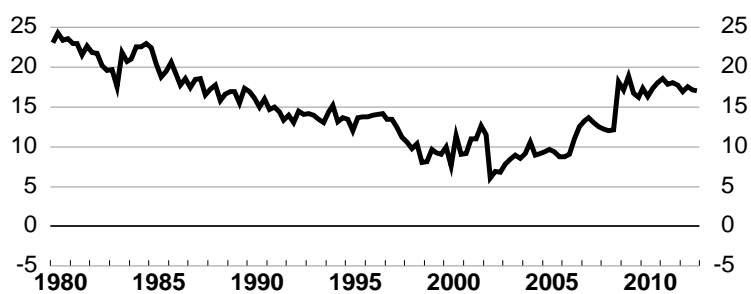

Greece

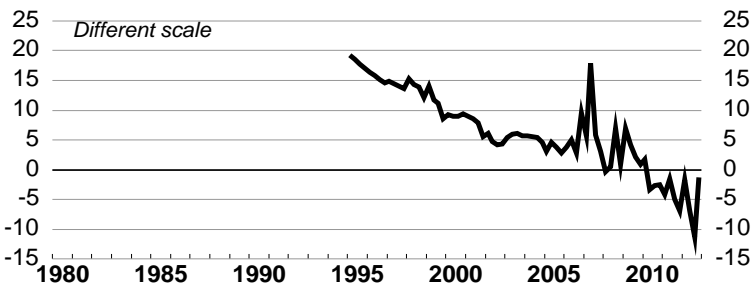

Korea

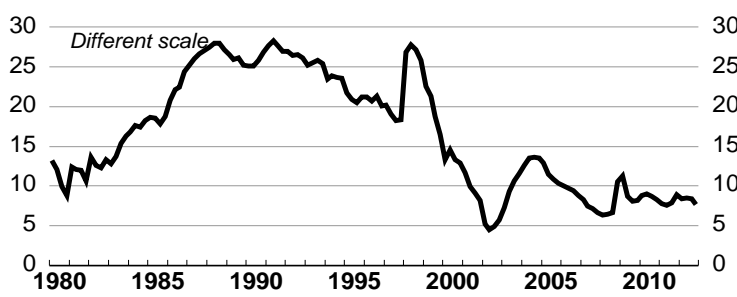

Portugal

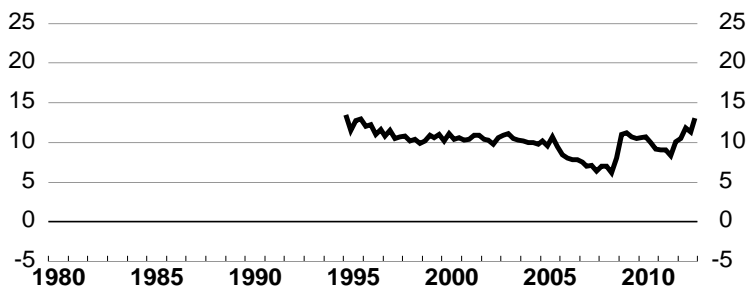

Sweden

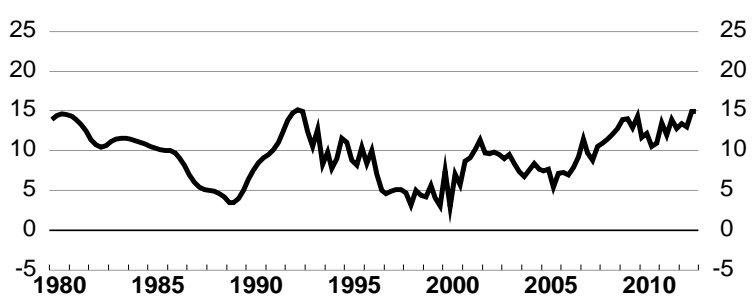

Belgium

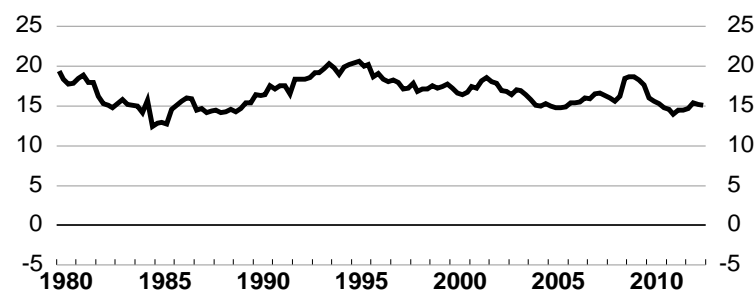

Irland

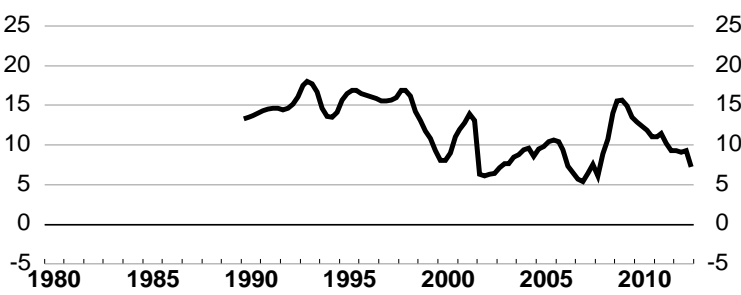

Netherlands

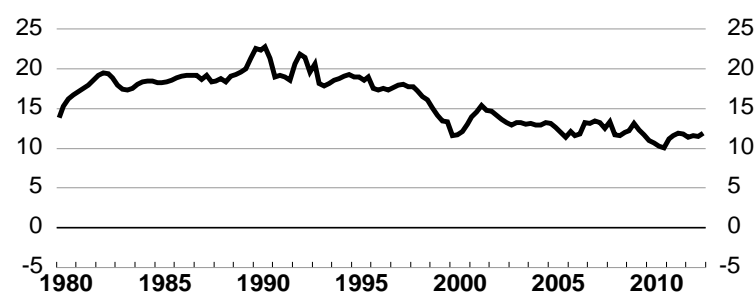

Spain

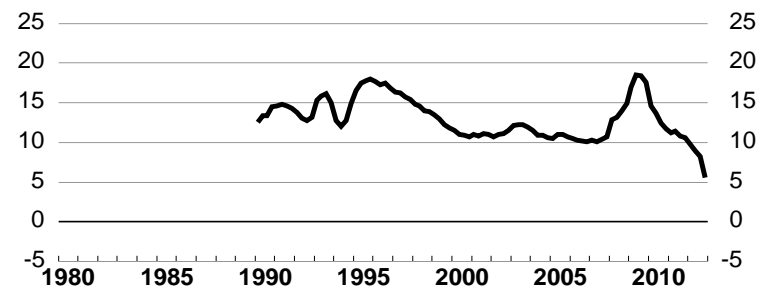

Switzerland

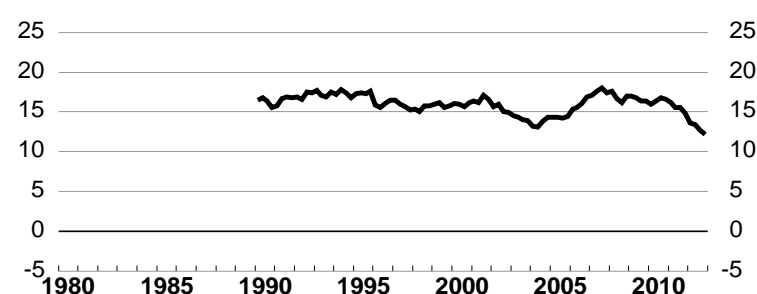

Source: OECD Economic Outlook database no. 93. 
Figure 11. Debt reduction and changes in household saving and residential investment ratios
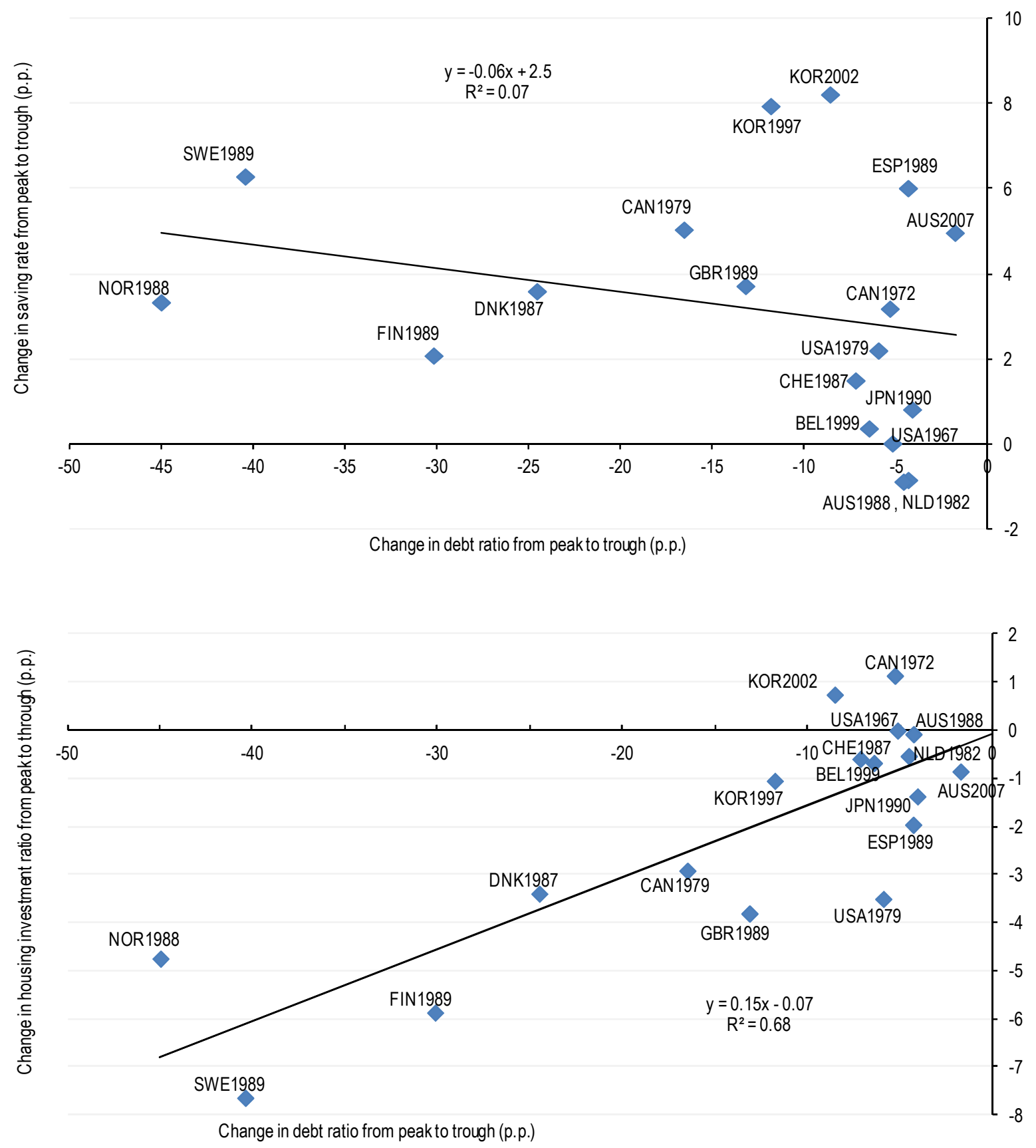
Figure 12. Residential investment rates over 1980-2012

Residential-investment-to-gross-disposable-income ratio

United States

$\%$

10
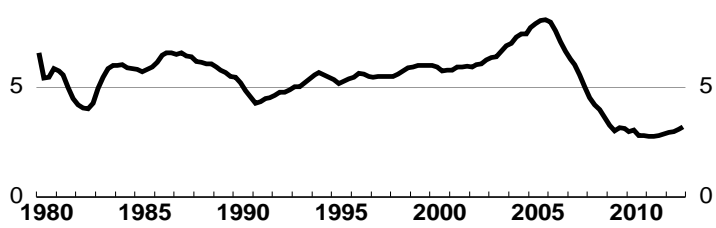

Germany
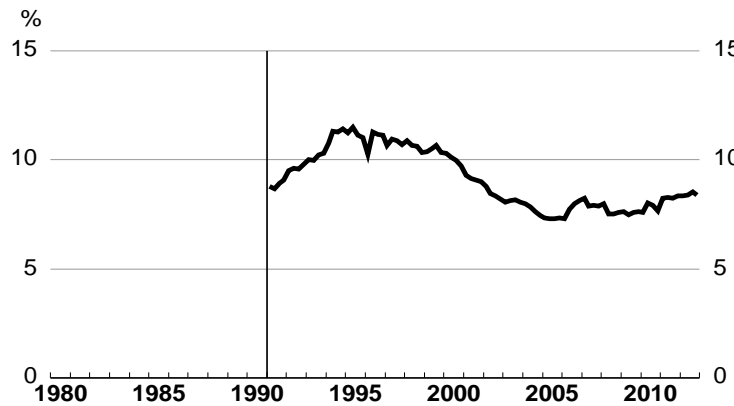

Italy

$\%$
15
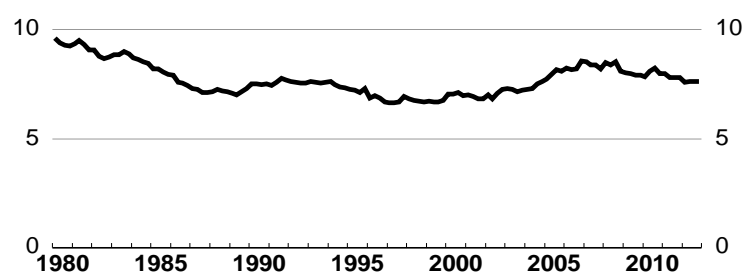

Canada

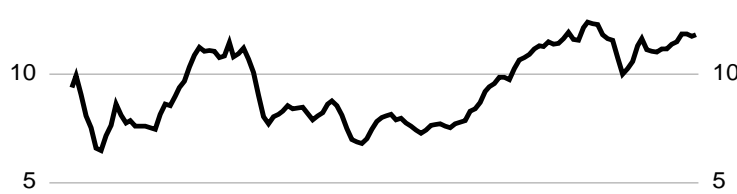

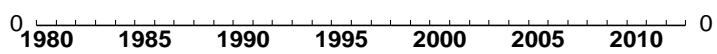

Japan
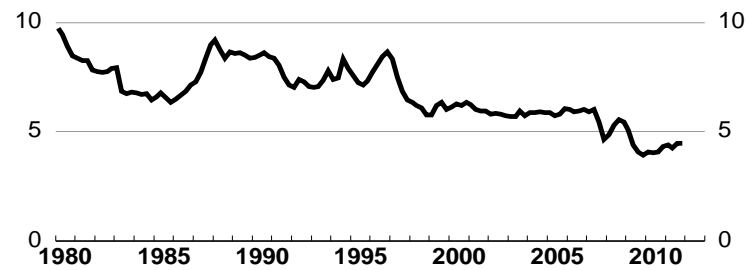

France

$\%$

15

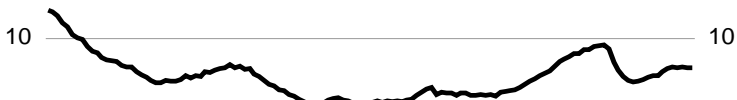

5

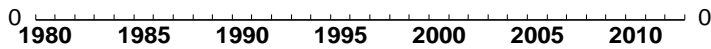

United Kingdom

$\%$

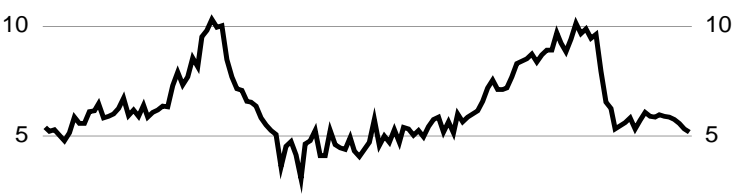

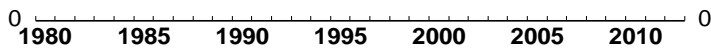

Euro area

$\%$

15

10

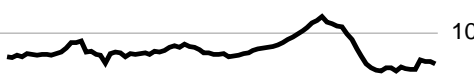

5

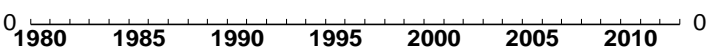

Source: OECD Economic Outlook database no. 93. 
Figure 12. Residential investment rates over 1980-2012 (cont.)

Residential-investment-to-gross-disposable-income ratio

Australia

$\%$

15

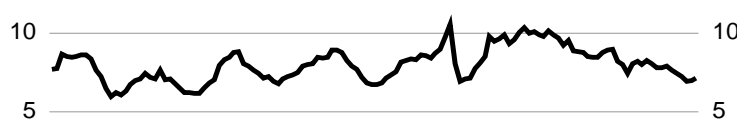

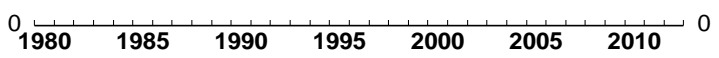

Greece

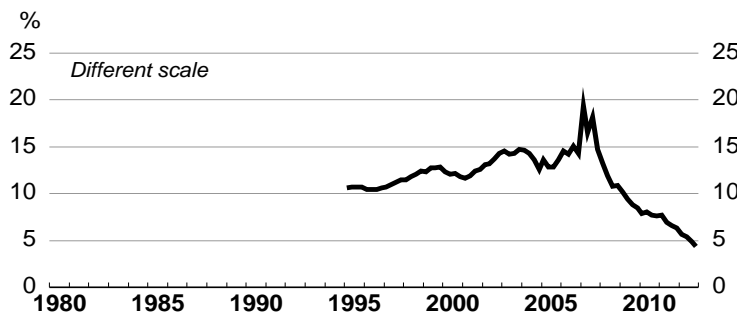

Korea

$\%$
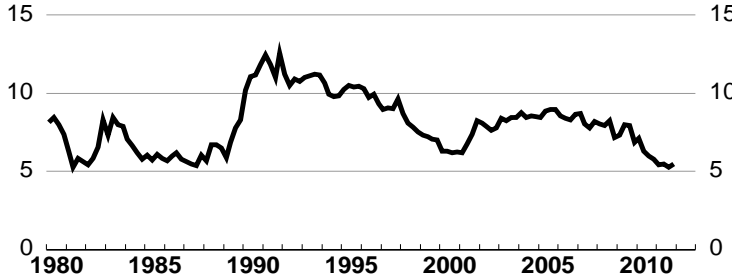

Portugal
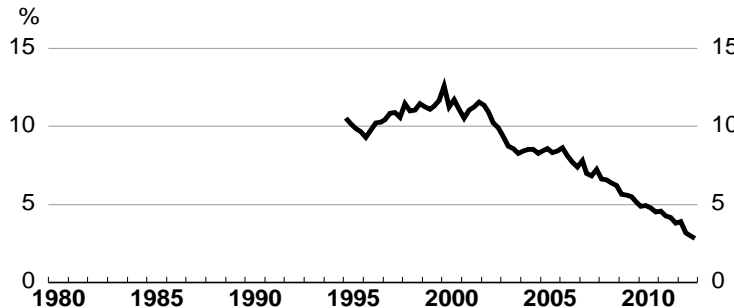

Sweden

$\%$

15

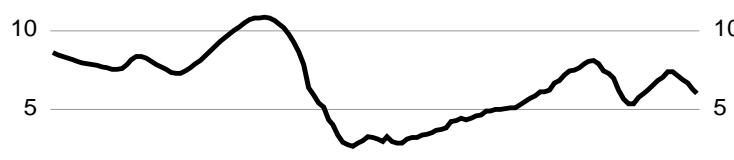

$\begin{array}{llllllll}0 & 1980 & 1985 & 1990 & 1995 & 2000 & 2005 & 2010\end{array}$

Belgium

$\%$

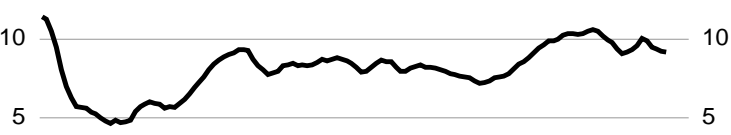

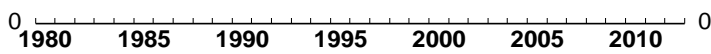

Irland

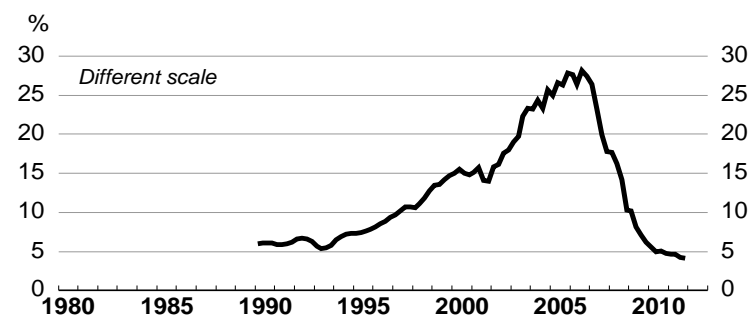

Netherlands

$\%$

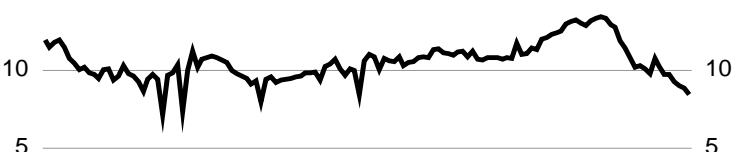

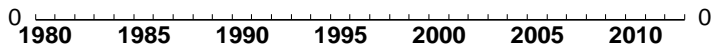

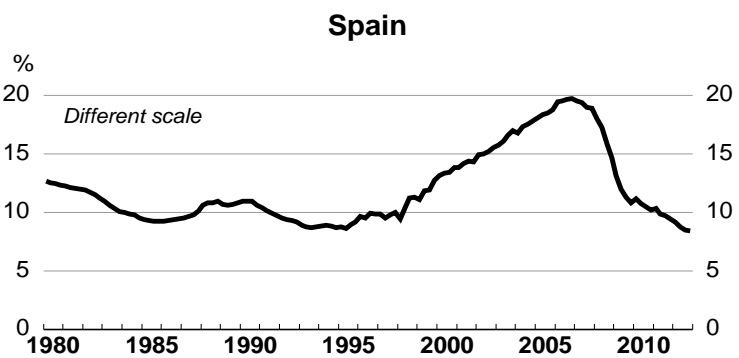

Switzerland

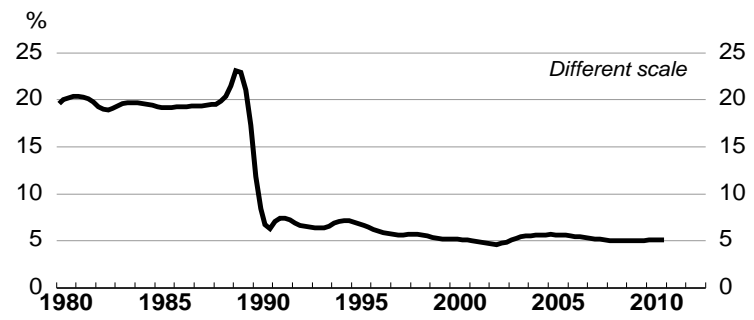

Source: OECD Economic Outlook database no. 93. 
Figure 13. Output gaps and non-performing loans

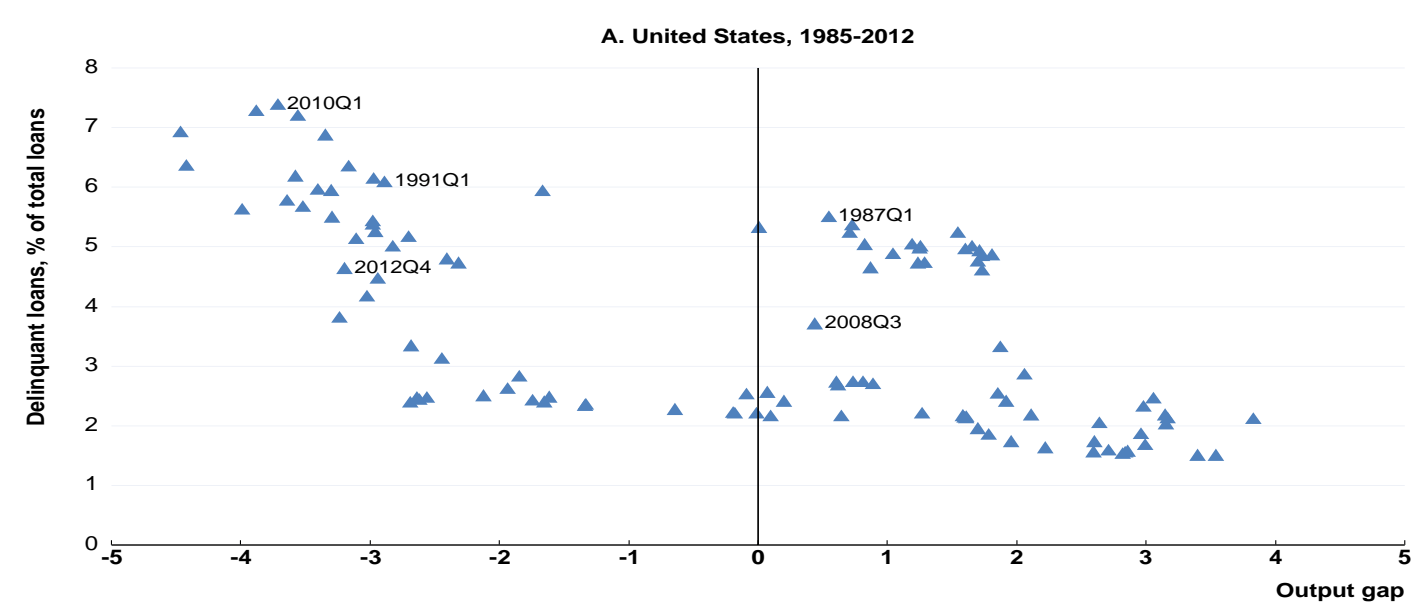

B. G7 countries, recent and early 2000 s

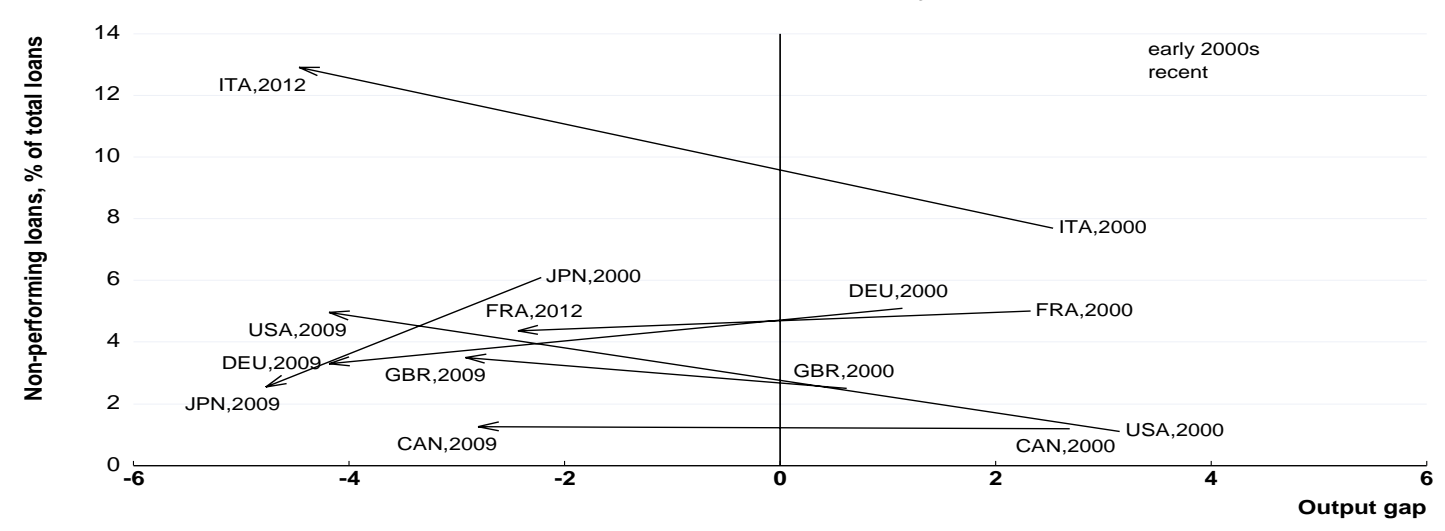

C. Selected OECD countries, recent and early 2000 s

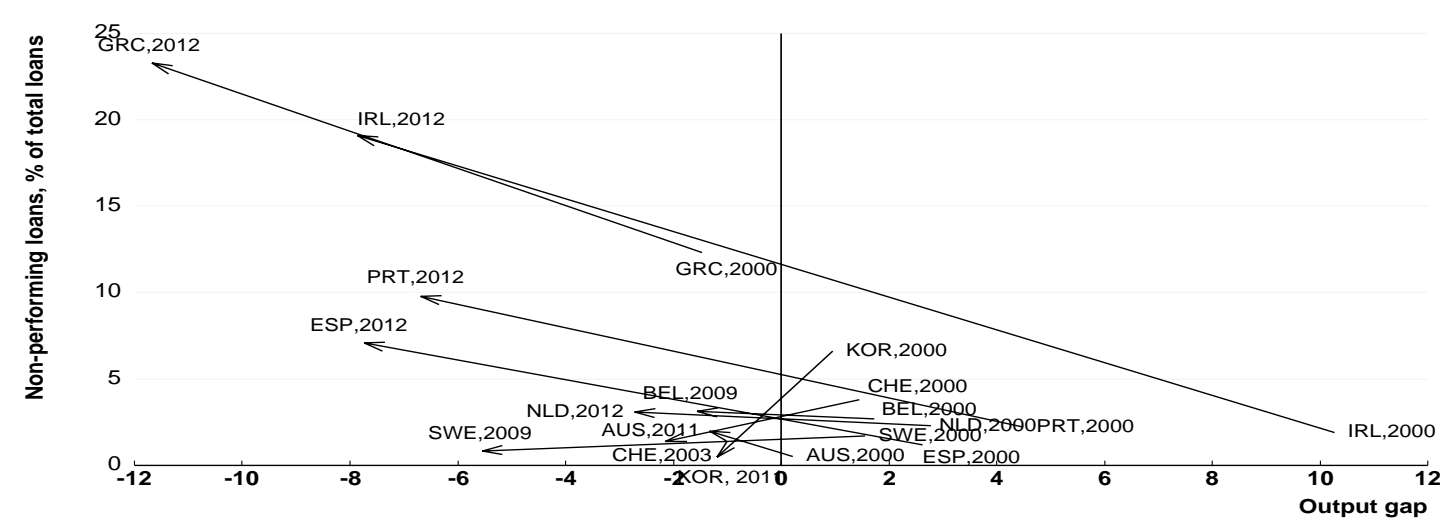

Source: Panel A: Federal Reserve and OECD Economic Outlook 93 database. Panel B: IMF Global Financial Stability Reports (2006, 2007,2009 ) and IMF Financial Soundness Indicators. 
Figure 14. General government debt-to-GDP ratio
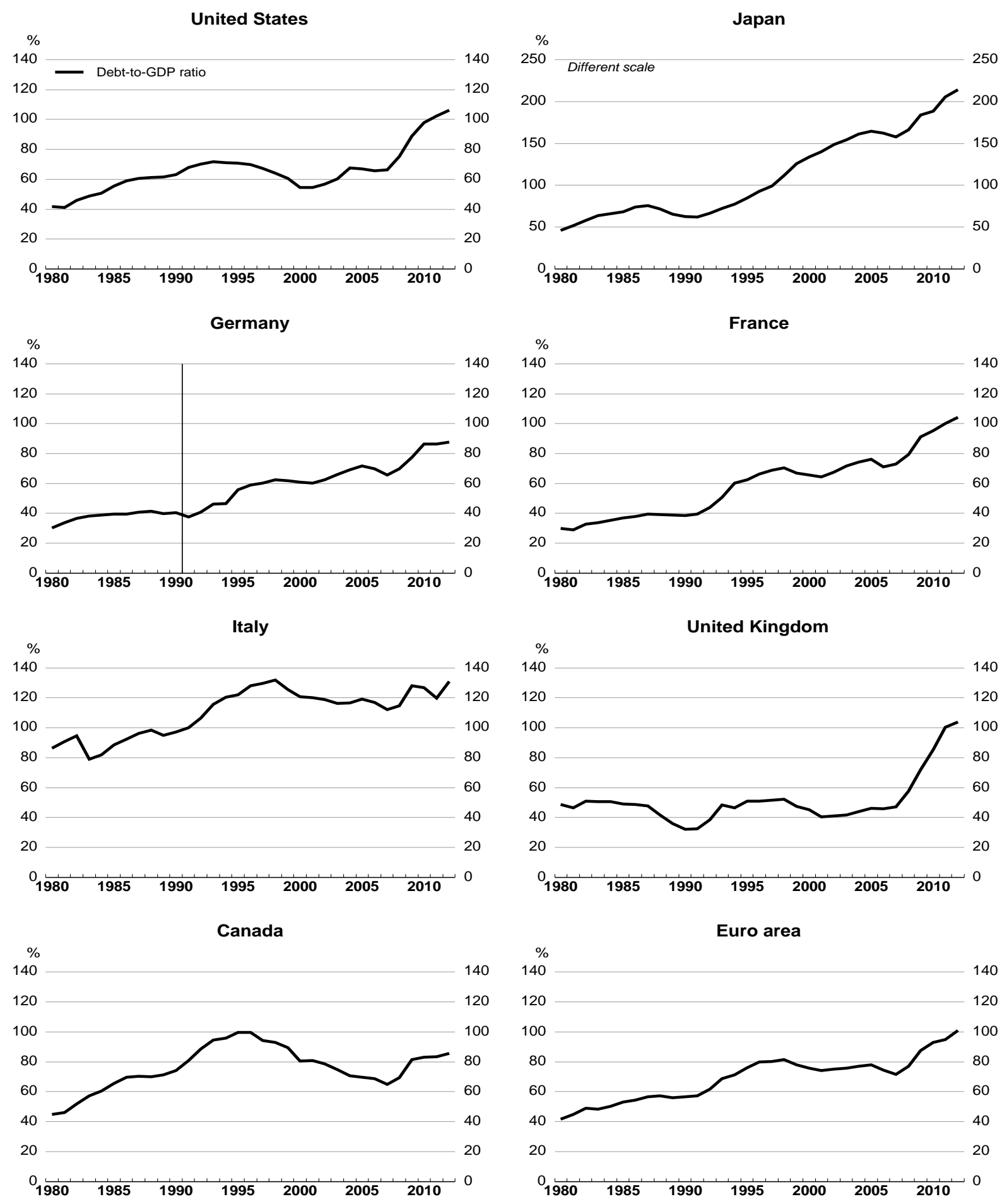

Note: Debt is calculated as total liabilities minus shares and other equities minus financial derivative.

Source: OECD national accounts, national statistical offices, national central banks, ECB, Eurostat, and OECD Economic Outlook database no. 93. 
Figure 14. General government debt-to-GDP ratio (cont.)
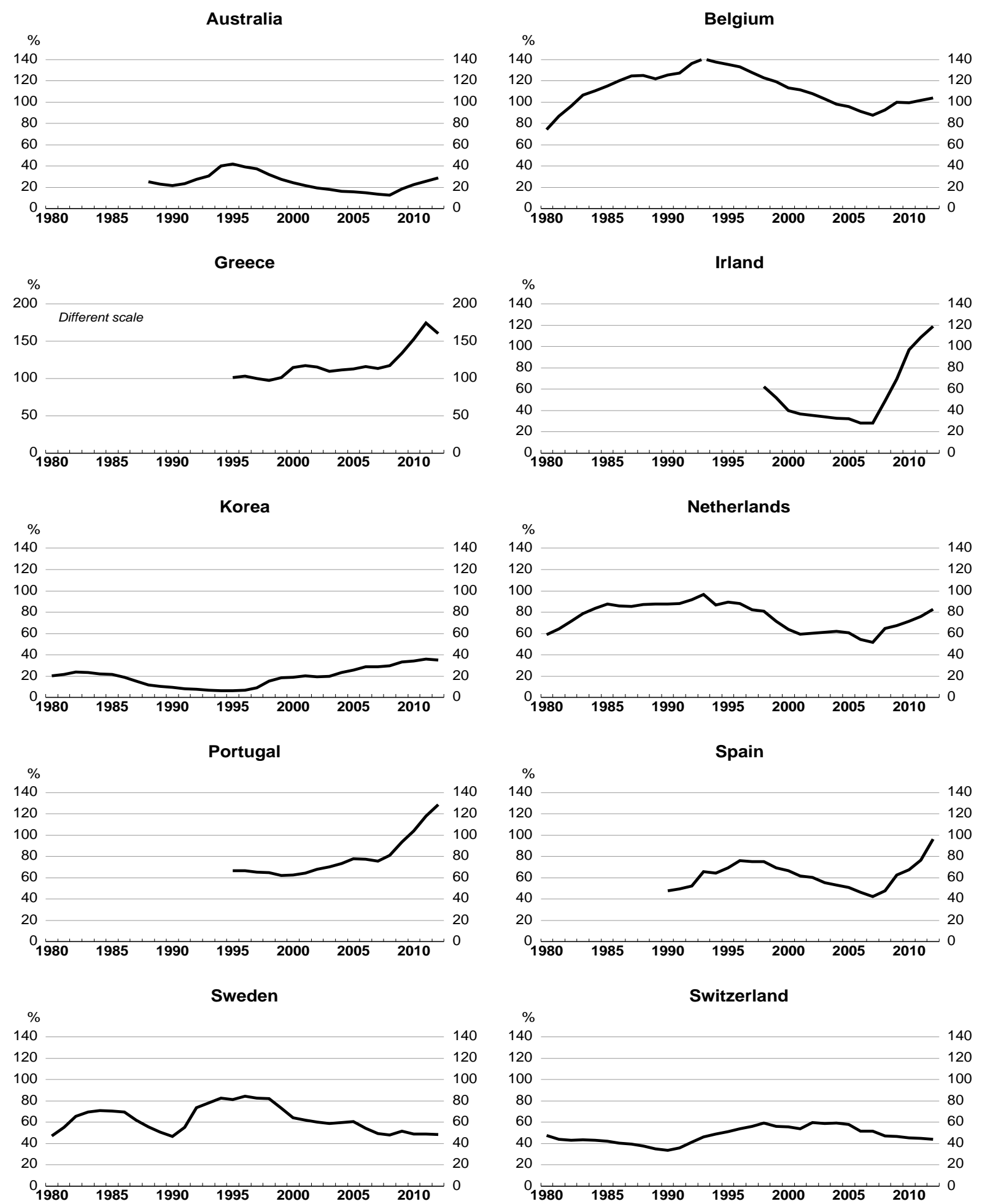

Note: Debt is calculated as total liabilities minus shares and other equities minus financial derivatives.

Source: OECD national accounts, national statistical offices, national central banks, ECB, Eurostat, and OECD Economic Outlook database no. 93. 


\section{REFERENCES}

Ahrend, R., B. Cournède, and R. Price (2008), "Monetary Policy, Market Excesses and Financial Turmoil", OECD Economics Department Working Papers, No. 597.

André, C. (2010), “A Bird's Eye View of OECD Housing Markets”, OECD Economics Department Working Papers, No. 746.

Bank for International Settlements (2010), Annual Report, Basel.

Barseghyan, L. (2010), “Non-Performing Loans, Prospective Bailouts, and Japan's Slowdown”, Journal of Monetary Economics, Vol. 57, Issue 1, pp. 873-890.

Bergoeing, R., P. J. Kehoe, T.J. Kehoe and R. Soto (2007), “A Decade Lost and Found: Mexico and Chile in the 1980s", in Kehoe, P. and E. Prescott (eds), Great Depressions of the Twentieth Century, Federal Reserve Bank of Minneapolis.

Bhutta, N. (2012), "Mortgage Debt and Household Deleveraging: Accounting for the Decline in Mortgage Debt Using Consumer Credit Record Data", Federal Reserve Board FEDS Working Paper No. 2012-14.

Blundell-Wignall, A. and P. Atkinson (2011), "Global SIFIs, Derivatives and Financial Stability", OECD Journal: Financial Market Trends, Vol. 2011, Issue 1.

Blundell-Wignall, A. and P. Atkinson (2012), "Deleveraging, Traditional versus Capital Market Banking and the Urgent Need to Separate and Recapitalise G-SIFI banks", OECD Journal: Financial Market Trends, Vol. 2012, Issue 1.

Borio, C., B. Vale, and G. von Peter (2010), "Resolving the Financial Crisis: Are we Heeding the Lessons from the Nordics?", BIS Working Papers No. 311.

Brock, P. (2009), "Transforming Bad Banks into Good Banks: Lessons from the Chilean Financial Crisis", George Washington University Working Paper No. 2009-10.

Caballero, R., T. Hoshi, and A. Kashyap (2008), “Zombie Lending and Depressed Restructuring in Japan”, American Economic Review, Vol. 98, Issue 5, pp. 1943-1977.

Carroll, C., J. Slacalek, and M. Sommer (2012), "Dissecting Saving Dynamics: Measuring Wealth, Precautionary and Credit Effects", IMF Working Paper, No. 12/219.

Cecchetti, S., M. Mohanty, and F. Zampolli (2011), “The Real Effects of Debt”, BIS Working Papers No. 352. 
Córdoba, G. and T. Kehoe (2009), "The Current Financial Crisis: What Should We Learn from the Great Depressions of the Twentieth Century?", Research Department Staff Report, No. 421, Federal Reserve Bank of Minneapolis.

Dynan, K. and D. Kohn (2007), "The Rise in U.S. Household Indebtedness: Causes and Consequences", Finance and Economics Discussion Series 2007-37, Board of Governors of the Federal Reserve System.

Dynan, K. (2012), "Is a Household Debt Overhang Holding Back Consumption?", Brookings Papers on Economic Activity, Spring 2012, pp. 299-344.

Englund, P. (1999), "The Swedish Banking Crisis: Roots and Consequences", Oxford Review of Economic Policy, Vol. 15 No. 3, pp. 80-97.

Federal Housing Finance Agency (2012), "FHFA Analyses of Principal Forgiveness Loan Modification", January 20, 2012.

Federal Reserve Board (2012), "The U.S. Housing Market: Current Conditions and Policy Considerations", January 4, 2012.

Finocchiaro, D., C. Nilsson, D. Nyberg, and A. Soultanaeva (2011), "Household Indebtedness, House Prices and the Macroeconomy: a Review of the Literature", Sveriges Riksbank Economic Review No. 1, pp. 6-28.

Glick, R. and K. Lansing (2011), "Consumers and the Economy, Part I: Household Credit and Personal Saving", FRBSF Economic Letter No. 1, January.

Igan, D., D. Leigh, J. Simon, and P. Topalova (2012), "Repairing Household Balance Sheets", Presentation at the workshop on Private Sector Balance Sheet Sustainability, European Commission, January, Brussels.

Hoshi, T. and A. Kashyap (2008), "Will the US Bank Recapitalization Succeed? Lessons from Japan", NBER Working Paper, No. 14401.

Koo, R. (2011), "The World in Balance Sheet Recession: Causes, Cure, and Politics", Real World Economics Review No. 58, pp. 19-37.

Mian, A., K. Rao, and A. Sufi (2011), "Household Balance Sheets, Consumption, and the Economic Slump", mimeo, Princeton University and University of Chicago.

Mian, A. and A. Sufi (2011), "House Prices, Home Equity Based Borrowing, and the U.S. Household Leverage Crisis", American Economic Review 101, pp. 2132-2156.

Midrigan, V. and T. Philippon (2011), "Household Leverage and the Recession", NBER Working Paper No. 16965.

MGI (2010), Debt and Deleveraging: The Global Credit Bubble and its Economic Consequences, McKinsey Global Institute, January.

MGI (2012), Debt and Deleveraging: Uneven Progress on the Path to Growth, McKinsey Global Institute, January. 
Mody, A., F. Ohnsorge, and D. Sandri (2012), "Precautionary Savings in the Great Recession", IMF Working Paper No. 42.

OECD (2011), OECD Economic Survey - Japan, OECD.

OECD (2012a), "Chapter 1 - General Assessment of the Macroeconomic Situation", OECD Economic Outlook No. 91, Vol. 2012/1, May, OECD.

Roehn, O. (2010), "New Evidence on the Private Saving Offset and Ricardian Equivalence", OECD Economics Department Working Papers, No. 762.

Ruscher, E. and G. Wolff (2012), "Corporate Balance Sheet Adjustment: Stylised Facts, Causes and Consequences", Bruegel Working Paper, No. 3.

Slovik, P. (2012), "Systematically Important Banks and Capital Regulations Challenges", OECD Economics Department Working Papers, No. 916.

Sutherland, D. and P. Hoeller (2012), "Debt and Macroeconomic Stability: An Overview of the Literature and Some Empirics," OECD Economics Department Working Papers, No. 1006.

Sutherland, D., P. Hoeller, R. Merola and V. Ziemann (2012), "Debt and Macroeconomic Stability", OECD Economics Department Working Papers, No. 1003.

Tang, G. and C. Upper (2010), “Debt Reduction after Crises”, BIS Quarterly Review, September, pp. 2538.

US Department of the Treasury and Department of Housing and Urban Development (2011), Reforming America's Housing Finance Market - A Report to Congress, February 2011.

Watanabe, W. (2010) "Does a Large Loss of Bank Capital Cause Evergreening? Evidence from Japan", Journal of the Japanese and International Economies, Vol. 24, Issue 1, pp. 116-136. 


\section{APPENDIX: TECHNICAL NOTE ON SOURCES AND METHODS}

\section{A1. Methodology}

35. Long time series of debt and wealth by institutional sectors have been assembled for the purposes of this paper. They draw on national balance sheet statistics of financial assets and liabilities as well as of non-financial assets balance sheet. The data structure considered follows the SNA classification of National accounts.

36. A broad definition of debt is used, covering all outstanding non-equity liabilities: bonds, loans, insurance technical reserves as well as trade credits and advances etc. No explicit guidance is provided on debt in the SNA93 manual, though it recognises that debt in general includes all liabilities except equity and investment fund shares/units owed by an institutional sector. Equity and investment fund shares/units are excluded here because they do not require the repayment of principal nor interests. Financial derivatives (incl. employee stock options) are also excluded. Debt has been explicitely defined in SNA2008 (paragraph 22.104), as all liabilities that require payment or payments of interest. Using the SNA coding, debt is computed as total financial liabilities, AFLI minus shares and other equity, liabilities, AF5LI minus financial derivatives, AF34LI. For countries such as Canada and the United States that follow a different methodology, but publishes statistical supplements according to the SNA system, these supplements are used. Table 1 shows a simplified wealth balance sheet with its main entries and gives an overview of the structure according to which the data are collected.

37. The valuation of debt is in current market prices at the stock taking date; here end of year the 31 . December. For outstanding debt, current market prices are unlike the often used concepts of rcording debt in face value; remaining outstanding reimbursements.

The difference between two stock taking dates is measured in both a change of volume and change in value/price of each item. These two account are rarely available, therefore we only content to use the "overall" evolution between two periods.

Table A1. Accounts setup of wealth

\begin{tabular}{|c|c|}
\hline ASSETS, AF+AN & LIABILITIES, AFLI (collected) \\
\hline Non-financial assets, AN (collected) & Borrowed funds, AFLI-AF5LI - AF34 \\
\hline Produced assets & \\
\hline $\begin{array}{l}\text { Fixed assets (Dwellings, other building } \\
\text { structures, machinery, inventories and valuable } \\
\text { objects) }\end{array}$ & \\
\hline $\begin{array}{c}\text { Non-produced assets } \\
\text { Tangible non-produced assets (land, subsoil } \\
\text { assets and patented entities/purchased goodwill) }\end{array}$ & Own funds \\
\hline Financial assets, AF (collected) & Shares and other equity, AF5LI (collected) \\
\hline Currency & Financial derivatives, AF34 (collected) \\
\hline Securities & \\
\hline Shares & \\
\hline Other financial assets (including pension funds) & \\
\hline
\end{tabular}




\section{A2. Total economy and institutional sectors}

The database follows the SNA approach (Figure A1) defining the total domestic economy as all resident institutional units and grouping them into the five mutually exclusive institutional sectors shown in Table A2. They can be owned by public or national private or foreign controlled entities, as according to the definition of residence.

Table A2. Type of producer, principal activity and functions classified by sector

\begin{tabular}{|c|c|c|c|}
\hline Code & Sector & Type & Principal activity \\
\hline S.1 & $\begin{array}{l}\text { Total Economy (Domestic } \\
\text { Economy) }\end{array}$ & & \\
\hline S.11 & $\begin{array}{l}\text { The non-financial corporations } \\
\text { sector }\end{array}$ & $\begin{array}{l}\text { Market } \\
\text { producer }\end{array}$ & $\begin{array}{l}\text { Production of market goods and non-financial } \\
\text { services }\end{array}$ \\
\hline S.12 & The financial corporations sector & $\begin{array}{l}\text { Market } \\
\text { producer }\end{array}$ & $\begin{array}{l}\text { Financial intermediation incl. insurance } \\
\text { Auxiliary financial activities }\end{array}$ \\
\hline S.13 & The general government sector & $\begin{array}{l}\text { Non-market } \\
\text { producer }\end{array}$ & $\begin{array}{l}\text { Production and supply of other non-market } \\
\text { output for collective and individual } \\
\text { consumption and carrying out transactions } \\
\text { intended to redistribute national income and } \\
\text { wealth }\end{array}$ \\
\hline S.14 & The households sector. & $\begin{array}{l}\text { Market } \\
\text { producer for } \\
\text { own final use }\end{array}$ & $\begin{array}{l}\text { Consumption } \\
\text { Production of market output and for own final } \\
\text { use }{ }^{14}\end{array}$ \\
\hline S.15 & $\begin{array}{l}\text { The non-profit institutions } \\
\text { serving households sector }\end{array}$ & $\begin{array}{l}\text { Private other } \\
\text { non-market } \\
\text { producer }\end{array}$ & $\begin{array}{l}\text { Production and supply of other non-market } \\
\text { output for individual consumption }\end{array}$ \\
\hline
\end{tabular}

Source: ESA 1995 manual, page 21/SNA93, table 4.1, page 105.

The household sector mentioned in this paper referes to the aggregate account of the households and nonprofit institutions serving households sector, S.14 + S.15, as data for the household sector alone are not published and to get a comparable dataset.

\section{A3. Consolidation}

38. Not all countries compile consolidated balance sheets for institutional sectors through netting out intra-sector debt positions. The OECD collects consolidated data for Australia, Belgium, France, Germany, Greece, Ireland, Italy, Netherlands, Portugal, Spain and Sweden. The data received from Canada, Japan, Korea, Switzerland, United Kingdom and USA is not consolidated. The present database incorporates consolidated data when they are available and unconsolidated data otherwise. The choice of consolidated data is one of the reasons why the database has been built at an annual frequency, as OECD-collected quarterly balance sheet data is not consolidated.

\section{A4. Availability}

39. The availability of long time series varies substancely among countries. The OECD national accounts database has reasonably good data coverage for OECD countries from 1995 to 2010. For all

\footnotetext{
${ }^{14}$ The households sector includes production of market output, where the production of the good cannot be separated from the household unit.
} 
countries except Canada, Japan and the United States, data compliant with SNA 1993 standards are not available before 1995. For the purposes of this study, such series have been retropolated or backdated using data from old compilations using often national classifications. Retropolation is based on the first common period link method, where the level of the new series and growth rates of old series are reflected in the final time series.

40. Data on government financial assets and liabilities are taken from the Economic Outlook No. 93 database. For the Netherlands, Belgium and Switzerland, estimates for non-financial corporation debt to GDP has been taken from the BIS working paper no. 352, Cecchetti, Mohanty and Zampolli(2011) (they are using bank balancesheets of credit to households and non-financial corporations).

41. Detailed information about data availability by country and sector is given in Table A3.

\section{A5. Country specific notes}

\section{A5.1 USA}

42. Data from 1960 are available in OECD national accounts. Data are not consolidated.For the general government account data from the table "L.106.C - Consolidated Statement for Federal, State and Local Government" were chosen since transactions between federal entities and state and local entities are netted out, so that for example state and local government holdings of Tresury securities are not included. The data used from the table is total financial assets and total liabilities.

43. Flow of funds published by the US Federal Reserve also show Integrated Macroeconomic Accounts for the United States by institutional sector based on international guidelines and terminology spelled out in the System of National Accounts 1993 (revised in 2008). For more detail on these accounts, see Bond et al. (2007). These accounts are used for gross operating surplus of the non-financial corporations sector.

\section{A5.2 Japan}

44. Data for operating surpluses for non-financial corporations are computed as a proxy by data for operating surpluses for total economy, calculated as nominal GDP minus employee compensations. Data are available from 1980 in OECD national accounts. They are not consolidated and follow the SNA93 manual. These data are collected from National Accounts made by Cabinet Office.

\section{A5.3 Germany}

45. Data from 1991 are available in OECD national accounts. This date coincides with German reunification as well as a change in classification used to the ESA95 system. Thanks go to the Deutche Bundesbank for providing us with data from historical statistical publications of financial sector accounts from 1960 to 1992 (Deutsche Bundesbank, 1994). The two datasets are not directly comparable due to methodical and primary statistics changes. For instance, the data from 1960-1990 is based on the compilation of the financial accounts according to the European System of National Accounts 1979 (ESA 1979); whereas the data from 1992 onwards is based on ESA 1995. In addition, there was a steady need to revise the dataset during the time periods due to changes in the underlying primary statistics. Finally, the data before 1990 are data for West-Germany only.

\section{A5.4 France}

46. Consolidated data are available from 1995 in OECD national accounts. The Banque de France provides detailed historical data on its website from 1977 to 2009. The data are presented according to the 
ESA95 manual for all institutional sub-sectors. The necessary aggregation to obtain the institutional sectors for the financial corporations, general government and households and NPIs has been done by the authors of this study. The data are not consolidated.

\section{A5.5 Italy}

47. Historical data are available on the website of Banca d'Italia compiled according to ESA1995/SNA93 from 1950-1994, not consolidated nor aggregated for the financial and government sectors. OECD national accounts have data from 1995. Thanks go to Banca d'Italia for providing a dataset with an overlapping period allowing the construction of a complete series.

\section{A5.6 United Kingdom}

48. Data from 1975 to 1987 are taken from the publications "The CSO Blue Book of United Kingdom National Accounts; 1987 and 1994 editions. These data are not using the SNA93/ESA95 classifications. In September 1998, the definition of institutional sectors in UK national accounts was changed to follow ESA95/SNA93. The important changes are for the central bank, comprising the Issue and Banking Departments of the Bank of England, is a new subsector within monetary financial institutions and partnerships, formerly classified within the personal sector (households), are now 'quasi corporations', included within the corporate sectors. These components have not been taken into account when retropolating the relevant series for the purposes of the present study.

\section{A5.7 Canada}

49. Data from 1961 or 1970 are taken from OECD national accounts. The data are not consolidated.

\section{A5.8 Netherlands}

50. The data for the household sector is retropolated by data collected and send by 'CPB Netherlands Bureau for Economic Policy Analysis (CPB)' during the work on the Global model project in 2007. The data are not presented according to SNA nor ESA classification, but represent a time span of 1980 to 2007. For household total assets, the variation in liquid assets is used, for total liabilities, the variation in debt, a sum of mortgages and other credits is used and for non-financial assets, the variation in owner occupied housing is used.

51. For non-financial corporations, data from the BIS study by Cecchetti et al. (2011) to retropolate OECD data. It should be noted that the data for the period 1980-1984 are estimates made by Cecchetti et al. (2011).

\section{A5.9 Sweden}

Sweden has a special form of house ownership within housing co-operatives. The ownership of equity in the housing co-operative gives the right to live in a housing unit of the housing co-operative, but a monthly rent is requested to debt servicing, reparation and maintenance etc. of the housing co-operative. This type of housing can be considered equivalent to cooperative membership and a monthly service payment. In the Statistical office, the membership/equity is considered as a financial asset and is recorded in the financial balance sheet. The Central Bank follows a different approach and adds the equity to housing wealth and reduces the financial assets correspondingly. The central bank calls this form of housing tenant owned apartments'. We are using the Statistical office definition. The national statistical office publishes financial accounts from 1980. 


\section{A5.10 Australia}

The data for the household sector is retropolated by data collected during a former study for OECD's new global by Hervé et al. 2010. The non-financial assets are here represented by the dwellings and retropolated using the total economy capital stock of dwellings in market prices.

Financial assets and liabilities are retopolated using data from Reserve Bank of Australia's statistical data for occasional papers, table 3.25 and 3.26 respectively financial assets and liabilities of the household sector. The tables do not have a complete set of items before 1989; therefore the retropolation conductor is a bank balance sheets assets and liabilities towards the households.

For the non-financial corporations, data from the BIS study by Cecchetti et al. (2011) to retropolate OECD data. OECD data are consolidated from 1989 to 2012.

\section{A5.11 Greece}

There is no data on non-financial assets for households available.

\section{A5.12 Ireland}

For the household Consolidated data are available from 2001 to 2011. There is no balance sheet of nonfinancial assets.

\section{A5.13 Portugal}

The data for the household sector is retropolated by data from "Economic Bulletin, summer 2012" of Banco de Portugal. A table with estimate of household wealth of financial and non-financial wealth from 1980 to present is published as annex.

For the non-financial sector, data from the BIS study by Cecchetti et al. (2011) to retropolate OECD data.

\section{A5.14 Spain}

The data for non-financial asset of households are from Banco d'Espagna covering dwellings of households available from 1987 to 2012 on a quarterly basis.

\section{A5.15 Korea}

OECD data are available from 2002 to 2011 on an unconsolidated basis. The data have been retropolated using older versions of the OECD data available from 1970 to 2003. The data for non-financial assets of the households are retropolated from 1997 of the OECD data. The conducting series is an estimated using 3 survey points of households assets, residential buildings in gross value of 1977, 1987 and 1997. The surveys are from the national statistical office, collected in by the OECD in 2006. The function is using the 1987 - point as central point. The household residential buildings are a function of investment in housing, housing prices and the GDP price deflator.

\section{A5.16 Euro area}

Eurostat publish both consolidated and non-consolidated data for the Euro area of 17 countries. The consolidated data are from 1995 and the non-consolidated from 1980. The non-consolidated data present a sharp break in 1994 to 1995, why the, though shorter, consolidated data are used. 
Table A3. Detailed data sources

S.11, Non-financial corporations

AF, Financial assets

\begin{tabular}{|c|c|c|c|c|c|c|c|}
\hline \multicolumn{8}{|c|}{ r, rmanclai assets } \\
\hline & \multicolumn{7}{|c|}{ Sources } \\
\hline & \multicolumn{3}{|c|}{ OECD } & \multicolumn{2}{|c|}{ Other international organisations } & \multicolumn{2}{|c|}{ National sources } \\
\hline & $\begin{array}{c}\text { SNA } \\
\text { consolidated }\end{array}$ & $\begin{array}{c}\text { SNA not } \\
\text { consolidated }\end{array}$ & $\begin{array}{l}\text { SNA } \\
\text { Quarterly not } \\
\text { consolidated }\end{array}$ & BIS & Eurostat & Central bank & Statistical office \\
\hline USA & & $1960-2012$ & & & & & \\
\hline JPN & & $1980-2011$ & 2012 Q3 & & & $1980-2011$ & 1969-1979: ANA68 \\
\hline DEU & $1991-2011$ & & 2012 Q4 & & & \multicolumn{2}{|c|}{ 1960-1992 old national classification } \\
\hline FRA & $1995-2011$ & & 2012 Q4 & & & 1977-1994(n-con) & \\
\hline ITA & $1995-20110$ & & 2012 Q4 & & & 1960-1994(n-con) & \\
\hline GBR & & $1987-2012$ & & & & & 1975-87: Blue book ed.1987\&1994 \\
\hline CAN & & $1970-2011$ & 2012 Q1 & & & & 2012 Q2 \\
\hline EA17 & & & 2012 Q4 & & $1995-2011$ & & \\
\hline AUS & $1989-2012$ & & & & & & \\
\hline BEL & $1994-2011$ & & 2012 Q4 & & & & \\
\hline GRC & $1995-2011$ & & 2012 Q4 & & & & \\
\hline $\mathbb{R} \mathrm{R}$ & $2001-2011$ & & 2012 Q4 & & & & \\
\hline KOR & & $2002-2011$ & 2012 Q2 & & & & Older OECD versions $1970-2003$ \\
\hline NLD & $1990-2011$ & & 2012 Q4 & & & & $\begin{array}{l}\text { CPB Netherlands Bureau for } \\
\text { Economic Policy Analy sis } 1970 \\
\text { to } 2010\end{array}$ \\
\hline PRT & $1995-2011$ & & 2012 Q4 & & & & \\
\hline ESP & $1980-2011$ & & 2012 Q4 & & & & \\
\hline SWE & $1995-2012$ & & & & & & $1980-2012$ \\
\hline $\mathrm{CHE}$ & & $1999-2010$ & & & & & \\
\hline
\end{tabular}

AFLI, Financial liabilities

\begin{tabular}{|c|c|c|c|c|c|c|c|}
\hline \multicolumn{8}{|c|}{ 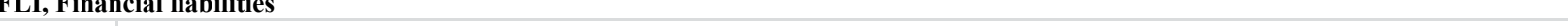 } \\
\hline & \multicolumn{7}{|c|}{ Sources } \\
\hline & \multicolumn{3}{|c|}{ OECD } & \multicolumn{2}{|c|}{ Other international organisations } & \multicolumn{2}{|c|}{ National sources } \\
\hline & $\begin{array}{c}\text { SNA } \\
\text { consolidated }\end{array}$ & $\begin{array}{c}\text { SNA not } \\
\text { consolidated }\end{array}$ & $\begin{array}{l}\text { SNA } \\
\text { Quarterly not } \\
\text { consolidated }\end{array}$ & BIS & EUROSTAT & Central bank & Statistical office \\
\hline USA & & $1960-2012$ & & & & & \\
\hline JPN & & $1980-2011$ & 2012 Q3 & & & 1980-2011; 2012 Q3 & 1969-1979: ANA68 \\
\hline DEU & $1991-2011$ & & 2012 Q4 & & & \multicolumn{2}{|c|}{ 1960-1992 old national classification } \\
\hline FRA & $1995-2011$ & & 2012 Q4 & & & 1977-1994(n-con) & \\
\hline ITA & $1995-2011$ & & 2012 Q4 & & & 1960-1994(n-con) & \\
\hline GBR & & $1987-2012$ & & & & & 1975-87: Blue book ed.87\&94; \\
\hline CAN & & $1970-2011$ & 2012 Q1 & & & & 2012 Q2 \\
\hline EA17 & & & 2012 Q4 & & $1995-2011$ & & \\
\hline AUS & $1989-2012$ & & \multicolumn{3}{|c|}{ 1980-1989:debt-to-GDP } & & \\
\hline BEL & $1994-2011$ & & 2012 Q4 & \multicolumn{2}{|c|}{ 1980-1993:debt-to-GDP } & & \\
\hline GRC & $1995-2011$ & & 2012 Q4 & & & & \\
\hline $\mathbb{R L}$ & $2001-2011$ & & 2012 Q4 & & & & \\
\hline KOR & & $2002-2011$ & 2012 Q2 & & & & Older OECD versions $1970-2003$ \\
\hline NLD & $1990-2011$ & & 2012 Q4 & & & & $\begin{array}{l}\text { CPB Netherlands Bureau for } \\
\text { Economic Policy Analy sis } 1970 \\
\text { to } 2010\end{array}$ \\
\hline PRT & $1995-2011$ & & 2012 Q4 & & & & \\
\hline ESP & $1980-2011$ & & 2012 Q4 & & & & \\
\hline SWE & $1995-2012$ & & & & & & 1980-1994; 2012 Q2 \\
\hline $\mathrm{CHE}$ & & $1999-2010$ & & & & & \\
\hline
\end{tabular}




\section{ECO/WKP(2013)69}

S.11, Non-financial corporations (cont.)

AF5, Financial liabilities, shares and other equity

\begin{tabular}{|c|c|c|c|c|c|c|c|}
\hline & \multicolumn{7}{|c|}{ Sources } \\
\hline & \multicolumn{3}{|c|}{ OECD } & \multicolumn{2}{|c|}{ Other international organisations } & \multicolumn{2}{|c|}{ National sources } \\
\hline & $\begin{array}{c}\text { SNA } \\
\text { consolidated }\end{array}$ & $\begin{array}{l}\text { SNA not } \\
\text { consolidated }\end{array}$ & $\begin{array}{c}\text { SNA } \\
\text { quarterly not } \\
\text { consolidated }\end{array}$ & BIS & Eurostat & Central bank & Statistical office \\
\hline USA & & $1960-2012$ & & & & & \\
\hline JPN & & 1980-2011 & 2012 Q3 & & & 1980-2011; 2012 Q2 & 1969-1979: ANA68 \\
\hline DEU & 1991-2011 & & 2012 Q4 & & & 1960-92 (old national classification) & \\
\hline FRA & 1995-2011 & & 2012 Q4 & & & 1977-1994(n-con) & \\
\hline ITA & $1995-2011$ & 2012 Q2 & & & & 1960-1994(n-con) & \\
\hline GBR & & $1987-2012$ & & & & & 1975-87: Blue book ed.87\&94 \\
\hline CAN & & $1970-2011$ & 2012 Q1 & & & & 2012 Q2 \\
\hline EA17 & & & 2012 Q4 & & $1995-2011$ & & \\
\hline AUS & $1989-2012$ & & & & & & \\
\hline BEL & 1994-2011 & & 2012 Q4 & & & & \\
\hline GRC & $1995-2011$ & & 2012 Q4 & & & & \\
\hline IRL & 2001-2011 & & 2012 Q4 & & & & \\
\hline KOR & & 2002-2011 & 2012 Q2 & & & & Older OECD versions $1970-2003$ \\
\hline NLD & 1990-2011 & & 2012 Q4 & & & & \\
\hline PRT & $1995-2011$ & & 2012 Q4 & & & & \\
\hline ESP & 1980-2011 & & 2012 Q4 & & & & \\
\hline SWE & $1995-2012$ & & & & & & 1980-1994; 2012 Q2 \\
\hline CHE & & $1999-2010$ & & & & & \\
\hline
\end{tabular}

AF34, Financial liabilities, financial derivatives

\begin{tabular}{|c|c|c|c|c|c|c|c|}
\hline & \multicolumn{7}{|c|}{ Sources } \\
\hline & \multicolumn{3}{|c|}{ OECD } & \multicolumn{2}{|c|}{ Other international organisations } & \multicolumn{2}{|c|}{ National sources } \\
\hline & $\begin{array}{c}\text { SNA } \\
\text { consolidated }\end{array}$ & $\begin{array}{c}\text { SNA not } \\
\text { consolidated }\end{array}$ & $\begin{array}{c}\text { SNA } \\
\text { Quarterly not } \\
\text { consolidated }\end{array}$ & BIS & Eurostat & Central bank & Statistical office \\
\hline USA & & $1960-2012$ & & & & & \\
\hline JPN & & 1980-2011 & 2012 Q3 & & & 1980-2011; 2012 Q3 & \\
\hline DEU & $1991-2011$ & & 2012 Q4 & & & & \\
\hline FRA & $1995-2011$ & 2012 Q2 & 2012 Q4 & & & & \\
\hline ITA & $1995-2011$ & $2012 \mathrm{Q} 2$ & 2012 Q4 & & & & \\
\hline GBR & & $1987-2012$ & & & & & \\
\hline \multicolumn{8}{|l|}{ CAN } \\
\hline EA17 & & & 2012 Q4 & & 1995-2011 & & \\
\hline AUS & $1989-2012$ & & & & & & \\
\hline BEL & $1994-2011$ & & 2012 Q4 & & & & \\
\hline GRC & 1995-2011 & & 2012 Q4 & & & & \\
\hline $\mathbb{R L}$ & $2001-2011$ & & 2012 Q4 & & & & \\
\hline KOR & & $2002-2011$ & 2012 Q2 & & & & Older OECD versions $1970-2003$ \\
\hline NLD & $1990-2011$ & & 2012 Q4 & & & & \\
\hline PRT & 1995-2011 & & 2012 Q4 & & & & \\
\hline ESP & $1980-2011$ & & 2012 Q4 & & & & \\
\hline SWE & $1995-2012$ & & & & & & $1980-2012$ \\
\hline CHE & & & & & & & \\
\hline
\end{tabular}

Note: AF34, financial derivatives. The data availability indicated is the dates where data are different from zero in the database SNA database. It is difficult to say from when financial derivatives enter in the accounts. 
ECO/WKP(2013)69

S.12, Financial corporations

AF, Financial assets

\begin{tabular}{|c|c|c|c|c|c|c|c|}
\hline & \multicolumn{7}{|c|}{ Sources } \\
\hline & \multicolumn{3}{|c|}{ OECD } & \multicolumn{2}{|c|}{ Other international organisations } & \multicolumn{2}{|c|}{ National sources } \\
\hline & $\begin{array}{c}\text { SNA } \\
\text { consolidated }\end{array}$ & $\begin{array}{c}\text { SNA not } \\
\text { consolidated }\end{array}$ & $\begin{array}{c}\text { SNA } \\
\text { quarterly not }\end{array}$ & BIS & Eurostat & Central bank & Statistical office \\
\hline USA & & $1960-2012$ & & & & & \\
\hline JPN & & $1980-2011$ & 2012 Q3 & & & $1980-2011$ & 1969-1979: ANA68 \\
\hline DEU & $1991-2011$ & & 2012 Q4 & & & \multicolumn{2}{|c|}{ 1960-1992 (old national classification) } \\
\hline FRA & $1995-2011$ & & 2012 Q4 & & & 1977-1994(n-con) & \\
\hline ITA & $1995-2011$ & & $2012 q 4$ & & & 1960-1994(n-con) & \\
\hline GBR & & $1987-2012$ & & & & & 1975-87: Blue book ed.87\&94 \\
\hline CAN & & $1970-2011$ & 2012 Q1 & & & & \\
\hline EA17 & & & 2012 Q4 & & $1995-2011$ & & \\
\hline AUS & $1989-2012$ & & & & & & \\
\hline BEL & $1994-2011$ & & $2012 q 4$ & & & & \\
\hline GRC & $1995-2011$ & & 2012 Q4 & & & & \\
\hline $\mathbb{R L}$ & $2001-2011$ & & 2012 Q4 & & & & \\
\hline KOR & & $2002-2011$ & 2012 Q2 & & & & Older OECD versions $1970-2003$ \\
\hline NLD & $1990-2011$ & & 2012 Q4 & & & & \\
\hline PRT & $1995-2011$ & & 2012 Q4 & & & & \\
\hline ESP & $1980-2011$ & & 2012 Q4 & & & & \\
\hline SWE & $1995-2012$ & & & & & & $1980-1994$ \\
\hline $\mathrm{CHE}$ & & $1999-2010$ & & & & & \\
\hline
\end{tabular}

AFLI, Financial liabilities

\begin{tabular}{|c|c|c|c|c|c|c|c|}
\hline \multicolumn{8}{|c|}{ L, , manclat navities } \\
\hline & \multicolumn{7}{|c|}{ Sources } \\
\hline & \multicolumn{3}{|c|}{ OECD } & \multicolumn{2}{|c|}{ Other international organisations } & \multicolumn{2}{|c|}{ National sources } \\
\hline & $\begin{array}{c}\text { SNA } \\
\text { consolidated }\end{array}$ & $\begin{array}{c}\text { SNA not } \\
\text { consolidated }\end{array}$ & $\begin{array}{c}\text { SNA } \\
\text { quarterly not }\end{array}$ & BIS & EUROSTAT & Central bank & Statistical office \\
\hline USA & & $1960-2012$ & & & & & \\
\hline JPN & & $1980-2011$ & 2012 Q3 & & & $1980-2011$ & 1969-1979: ANA68 \\
\hline DEU & $1991-2011$ & & 2012 Q4 & & & \multicolumn{2}{|c|}{ 1960-1992 (old national classification) } \\
\hline FRA & $1995-2011$ & & 2012 Q4 & & & 1977-1994(n-con) & \\
\hline ITA & $1995-2011$ & & 2012 Q4 & & & 1960-1994(n-con) & \\
\hline GBR & & $1987-2012$ & & & & & 1975-87: Blue book ed.87\&94 \\
\hline CAN & & $1970-2011$ & 2012 Q1 & & & & \\
\hline EA17 & & & 2012 Q4 & & $1995-2011$ & & \\
\hline AUS & $1989-2012$ & & & & & & \\
\hline BEL & $1994-2011$ & & 2012 Q4 & & & & \\
\hline GRC & $1995-2011$ & & 2012 Q4 & & & & \\
\hline $\mathbb{R L}$ & $2001-2011$ & & 2012 Q4 & & & & \\
\hline KOR & & $2002-2011$ & 2012 Q2 & & & & Older OECD versions $1970-2003$ \\
\hline NLD & $1990-2011$ & & 2012 Q4 & & & & \\
\hline PRT & $1995-2011$ & & 2012 Q4 & & & & \\
\hline ESP & $1980-2011$ & & 2012 Q4 & & & & \\
\hline SWE & $1995-2012$ & & & & & & $1980-1994$ \\
\hline $\mathrm{CHE}$ & & $1999-2010$ & & & & & \\
\hline
\end{tabular}




\section{ECO/WKP(2013)69}

S.12, Financial corporations (cont.)

AF5, Financial liabilities, shares and other equity

\begin{tabular}{|c|c|c|c|c|c|c|c|}
\hline & \multicolumn{7}{|c|}{ Sources } \\
\hline & \multicolumn{3}{|c|}{ OECD } & \multicolumn{2}{|c|}{ Other international organisations } & \multicolumn{2}{|c|}{ National sources } \\
\hline & $\begin{array}{c}\text { SNA } \\
\text { consolidated }\end{array}$ & $\begin{array}{c}\text { SNA not } \\
\text { consolidated }\end{array}$ & $\begin{array}{c}\text { SNA } \\
\text { quarterly not }\end{array}$ & BIS & Eurostat & Central bank & Statistical office \\
\hline USA & & $1960-2012$ & & & & & \\
\hline JPN & & $1980-2011$ & 2012 Q3 & & & 1980-2011, 2012 Q2 & \\
\hline DEU & 1991-2011 & & 2012 Q4 & & & 2012 Q2 & \\
\hline FRA & $1995-2011$ & & 2012 Q4 & & & 1977-1994 & \\
\hline ITA & $1995-2010$ & & 2012 Q4 & & & 1960-1994 & \\
\hline GBR & & $1987-2012$ & & & & & \\
\hline CAN & & $1970-2011$ & $2012 \mathrm{Q} 1$ & & & & 2012 Q2 \\
\hline EA17 & & & $2012 Q 4$ & & $1995-2011$ & & \\
\hline AUS & 1989-2012 & & & & & & \\
\hline BEL & 1994-2011 & & $2012 Q 4$ & & & & \\
\hline GRC & $1995-2011$ & & $2012 Q 4$ & & & & \\
\hline $\mathbb{R L}$ & $2001-2011$ & & $2012 Q 4$ & & & & \\
\hline KOR & & & $2012 \mathrm{Q} 2$ & & & & Older OECD versions $1970-2003$ \\
\hline NLD & 1990-2011 & & 2012 Q4 & & & & \\
\hline PRT & 1995-2011 & & $2012 Q 4$ & & & & \\
\hline ESP & $1980-2011$ & & 2012 Q4 & & & & \\
\hline SWE & $1995-2012$ & & & & & & 1980-1994, 2012 Q2 \\
\hline CHE & & $1999-2010$ & & & & & \\
\hline
\end{tabular}

AF34, Financial liabilities, financial derivatives

\begin{tabular}{|c|c|c|c|c|c|c|}
\hline & \multicolumn{6}{|c|}{ Sources } \\
\hline & \multicolumn{3}{|c|}{ OECD } & Other international organisations & \multicolumn{2}{|c|}{ National sources } \\
\hline & $\begin{array}{c}\text { SNA } \\
\text { consolidated }\end{array}$ & $\begin{array}{c}\text { SNA not } \\
\text { consolidated }\end{array}$ & $\begin{array}{c}\text { SNA } \\
\text { quarterly not }\end{array}$ & Eurostat & Central bank & Statistical office \\
\hline USA & & & & & & \\
\hline JPN & & 1997-2011 & 2012 Q3 & & 1997-2011 & \\
\hline DEU & & & & & & \\
\hline FRA & 1995-2011 & & 2012 Q4 & & & \\
\hline ITA & 1995-2011 & & 2012 Q4 & & & \\
\hline GBR & & $1999-2012$ & & & & \\
\hline CAN & & & & & & \\
\hline EA17 & & & 2012 Q4 & 1990-2011 & & \\
\hline AUS & & & & & & \\
\hline BEL & 2009-2010 & & 2012 Q4 & & & \\
\hline GRC & & & & & & \\
\hline IRL & & & 2012 Q4 & & & \\
\hline KOR & & & 2012 Q2 & & & \\
\hline NLD & 2000-2011 & & 2012 Q4 & & & \\
\hline PRT & & & 2012 Q4 & & & \\
\hline ESP & & & 2012 Q4 & & & \\
\hline SWE & 1996-2012 & & & & & \\
\hline CHE & & $1999-2010$ & & & & \\
\hline
\end{tabular}

Note: AF34, financial derivatives. The data availability indicated is the dates where data are different from zero in the database SNA database. It is difficult to say from when financial derivatives enter in the accounts. 
ECO/WKP(2013)69

S.14 S.15, Households and NPISHs

AF, Financial assets

\begin{tabular}{|c|c|c|c|c|c|c|c|c|}
\hline & \multicolumn{8}{|c|}{ Sources } \\
\hline & \multicolumn{4}{|c|}{ OECD } & \multicolumn{4}{|c|}{ Other } \\
\hline & $\begin{array}{c}\text { SNA } \\
\text { consolidated }\end{array}$ & $\begin{array}{c}\text { SNA not } \\
\text { consolidated }\end{array}$ & $\begin{array}{c}\text { SNA } \\
\text { quarterly not } \\
\text { consolidated }\end{array}$ & $\begin{array}{c}\text { EO } 93 \\
\text { database }\end{array}$ & BIS & Eurostat & Central bank & National sources \\
\hline USA & & $1960-2012$ & 2012 Q3 & $1960-2012$ & & & & Statistical office \\
\hline JPN & & $1980-2011$ & 2012 Q4 & $1970-2011$ & & & & \\
\hline DEU & $1991-2011$ & & 2012 Q4 & $1991-2011$ & & & $1960-1990$ & \\
\hline FRA & $1995-2011$ & & 2012 Q4 & $1978-2011$ & & & & \\
\hline ITA & $1995-2011$ & & & $1975-2010$ & & & & \\
\hline GBR & & $1987-2011$ & 2012 Q1 & $1987-2011$ & & & & \\
\hline CAN & & & & $1961-2011$ & & & & $1975-1986$ \\
\hline EA17 & & & 2012 Q4 & & & $1995-2011$ & & \\
\hline AUS & $1989-2012$ & & 2012 Q4 & & & & & \\
\hline BEL & $1994-2011$ & & 2012 Q4 & & & & & \\
\hline GRC & $1995-2011$ & & 2012 Q4 & & & & & \\
\hline $\mathbb{R L}$ & $2001-2011$ & & 2012 Q2 & & & & & \\
\hline KOR & & $2002-2011$ & 2012 Q4 & & & & & \\
\hline NLD & $1990-2011$ & & & $1990-2011$ & & & $1980-1989$ & $1980-1994$ \\
\hline PRT & $1995-2011$ & & 2012 Q4 & & & & & Older OECD versions $1970-2003$ \\
\hline ESP & $1980-2011$ & & 2012 Q4 & & & & & \\
\hline SWE & $1995-2011$ & & 2012 Q4 & $1995-2011$ & & & & \\
\hline CHE & & $1999-2011$ & & & & & & \\
\hline
\end{tabular}

AFLI, Financial liabilities

\begin{tabular}{|c|c|c|c|c|c|c|c|c|}
\hline & \multicolumn{8}{|c|}{ Sources } \\
\hline & \multicolumn{4}{|c|}{ OECD } & \multicolumn{4}{|c|}{ Other international organisations } \\
\hline & $\begin{array}{c}\text { SNA } \\
\text { consolidated }\end{array}$ & $\begin{array}{c}\text { SNA not } \\
\text { consolidated }\end{array}$ & $\begin{array}{l}\text { SNA } \\
\text { Quarterly not } \\
\text { consolidated }\end{array}$ & $\begin{array}{c}\text { EO } 93 \\
\text { database }\end{array}$ & BIS & Eurostat & Central bank & Statistical office \\
\hline USA & & $1960-2012$ & & $1960-2011$ & & & & \\
\hline JPN & & $1980-2011$ & & $1970-2010$ & & & & \\
\hline DEU & $1991-2011$ & & 2012 Q4 & $1991-2011$ & & & & \\
\hline FRA & $1995-2011$ & & 2012 Q4 & $1978-2011$ & & & & \\
\hline ITA & $1995-2011$ & & $2012 Q 4$ & $1975-2010$ & & & & \\
\hline GBR & & $1987-2012$ & & $1987-2012$ & & & & $1975-1986$ \\
\hline CAN & & $1970-2011$ & 2012 Q1 & $1961-2010$ & & & & \\
\hline EA17 & & & 2012 Q4 & & & $1990-2011$ & & \\
\hline AUS & $1989-2012$ & & & & & & $1977-1989$ & \\
\hline BEL & $1994-2011$ & & 2012 Q4 & $1995-2011$ & $1980-1994$ & & & \\
\hline GRC & 1995-2011 & & 2012 Q4 & & & & & \\
\hline $\mathbb{R L}$ & $2001-2011$ & & 2012 Q4 & & & & $\begin{array}{l}\text { CBI,Credit Adv anced to Irish } \\
\text { Resident Priv ate-Sector, } \\
\text { households, total } 1992 \text { - } 2002\end{array}$ & \\
\hline KOR & & $2003-2011$ & $2012 \mathrm{Q} 2$ & & & & & \\
\hline NLD & $1990-2012$ & & 2012 Q4 & $1990-2011$ & & & $1980-1989$ & \\
\hline PRT & $1995-2011$ & & 2012 Q4 & & & & & \\
\hline ESP & $1980-2011$ & & $2012 Q 4$ & & & & & \\
\hline SWE & $1995-2012$ & & & $1995-2011$ & & & & $1980-1994$ \\
\hline CHE & & $1999-2011$ & & $1999-2010$ & & & & \\
\hline
\end{tabular}


S.14_S.15, Households and NPISHs (cont.)

AF5, Financial liabilities, shares and other equity

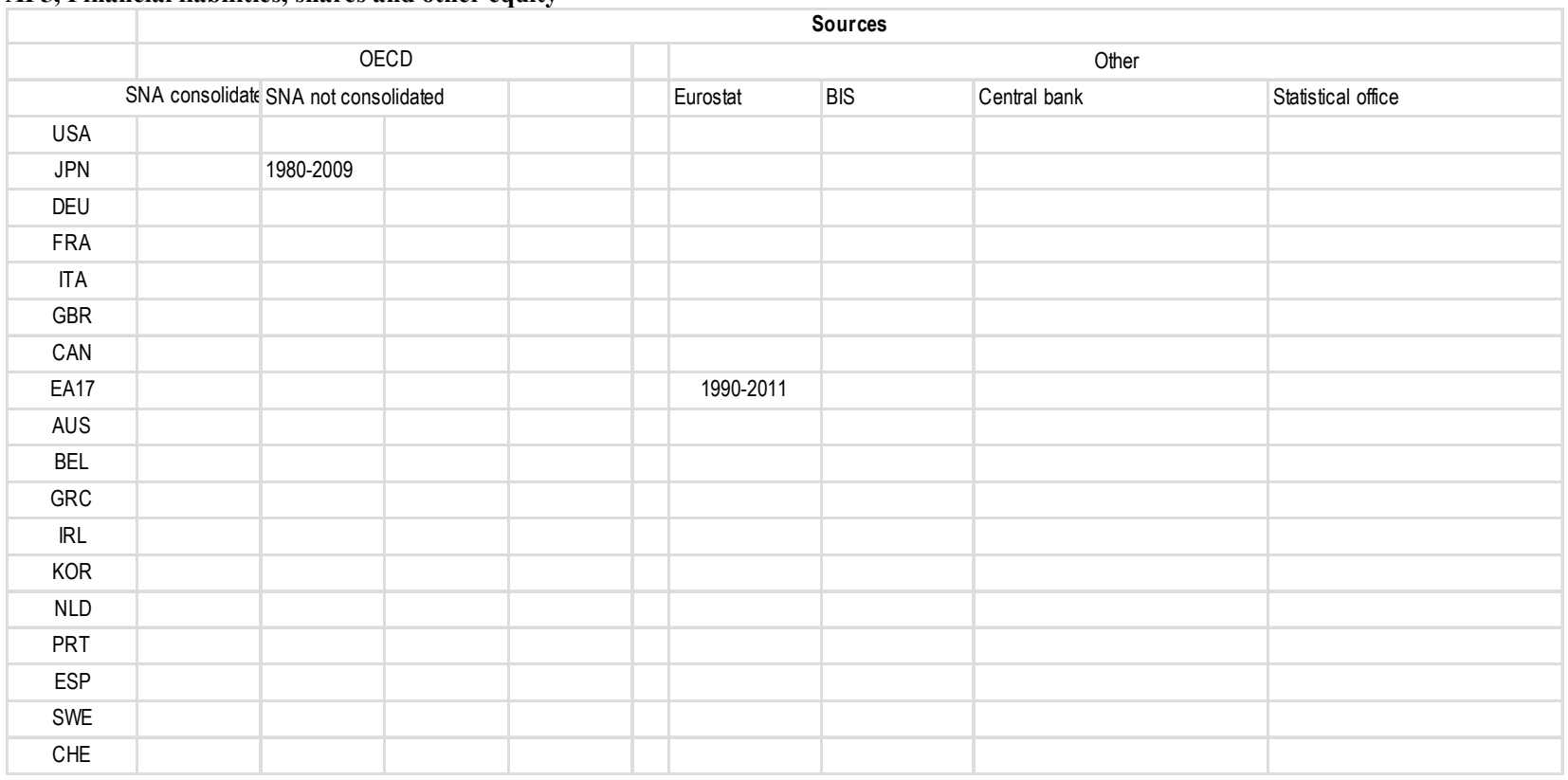

AF34, Financial liabilities, financial derivatives

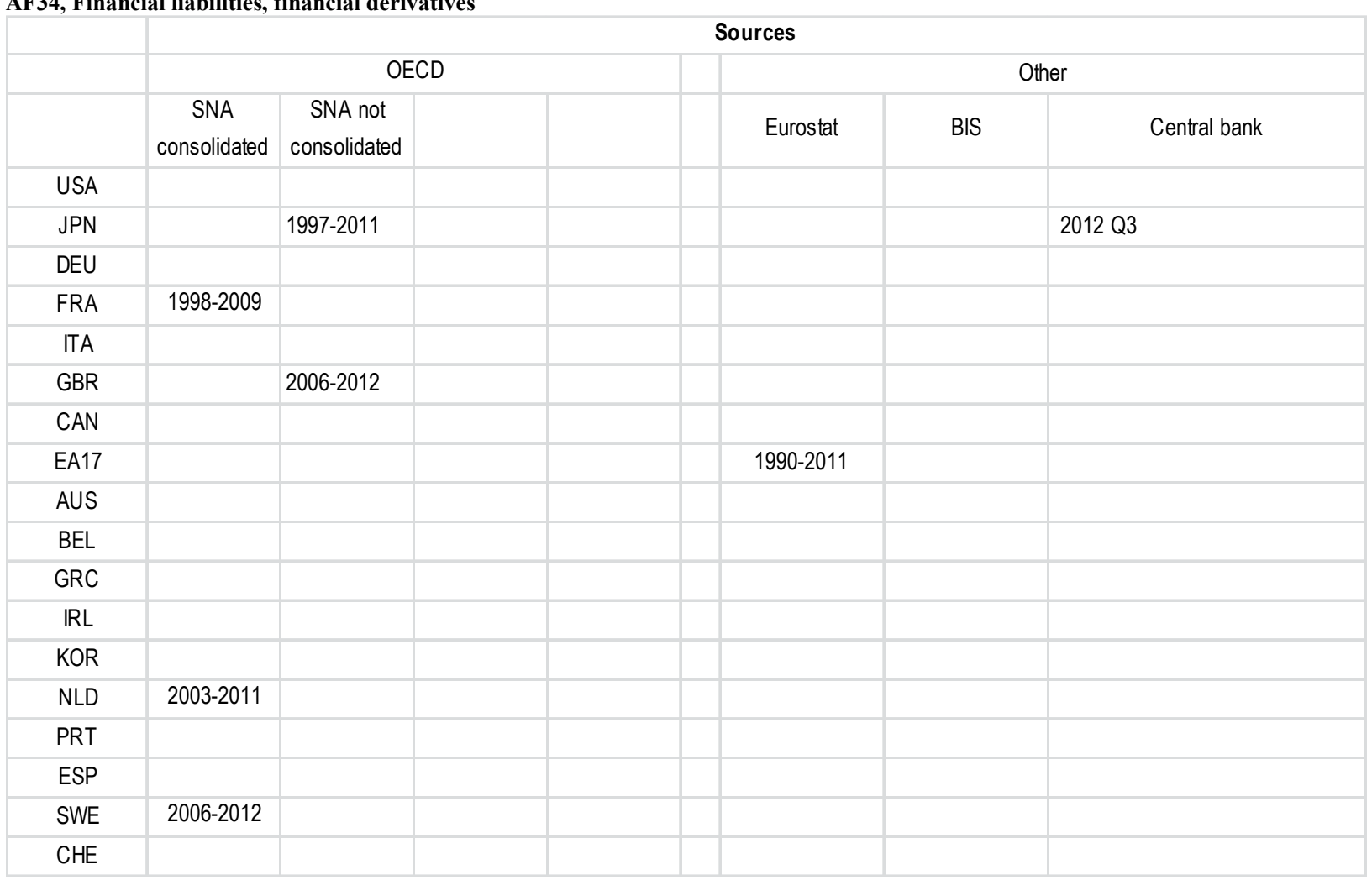


ECO/WKP(2013)69

S.14_S.15, Households and NPISHs (cont.)

AN, Non-financial assets

\begin{tabular}{|c|c|c|c|c|c|c|}
\hline & \multicolumn{6}{|c|}{ Sources } \\
\hline & \multicolumn{2}{|c|}{ OECD } & \multicolumn{2}{|r|}{ Other } & \multicolumn{2}{|c|}{ Meta data } \\
\hline & $\begin{array}{c}\text { SNA } \\
\text { av ailability }\end{array}$ & $\begin{array}{c}\text { EO } 93 \\
\text { database }\end{array}$ & Central bank & Statistical office & EO 93 database & proxy for retropolation \\
\hline USA & $1995-2011$ & $1960-2011$ & 2012 Q2 & & Non-financial assets & \\
\hline JPN & $1995-2011$ & $1970-2011$ & & & Non-financial assets & \\
\hline DEU & $1995-2011$ & $1991-2011$ & & $2009-2010$ & $\begin{array}{c}\text { produced fix ed } \\
\text { assets+consumer durables }\end{array}$ & Housing w ealth \\
\hline FRA & $1995-2011$ & $1978-2011$ & & & Non-financial assets ? & \\
\hline ITA & $1995-2008$ & $1975-2010$ & 2011 & & Housing w ealth & \\
\hline GBR & $1995-2010$ & $1987-2010$ & & 1975-1986, 2011 & Non-financial assets & \\
\hline CAN & $1995-2010$ & $1981-2011$ & & 2012 Q2 & $\begin{array}{l}\text { Residual of Netw orth minus Net } \\
\text { financial wealth }\end{array}$ & \\
\hline EA17 & & & & $1999-2011$ & & \\
\hline AUS & $1995-2012$ & & & Historical data capital stock:1968 - 2001 & & \\
\hline \multicolumn{7}{|l|}{ BEL } \\
\hline \multicolumn{7}{|l|}{ GRC } \\
\hline \multicolumn{7}{|l|}{$\mathrm{IRL}$} \\
\hline KOR & $1997-2011$ & & & Household survey: $1977,1987,1977$ & & Estimation: 1977-1997 \\
\hline NLD & $1996-2011$ & $1996-2011$ & $1980-1989$ & & Non-financial assets & 1980-89: Ow ner occupied housing \\
\hline PRT & & & $1980-2011$ & & & \\
\hline ESP & & & $1987-2012$ & & & \\
\hline SWE & & & & $1970-2011$ & & Dw ellings \\
\hline $\mathrm{CHE}$ & $2000-2011$ & $2000-2011$ & & $2000-2010$ & & Real estate/housing \\
\hline
\end{tabular}


Figure A1. Illustrative allocation of units to institutional sectors

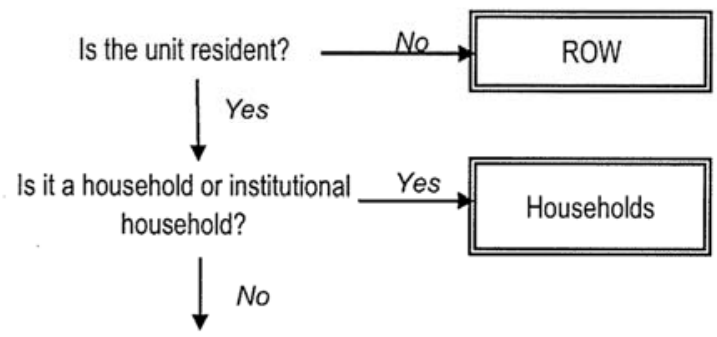

Is it a non-market producer?

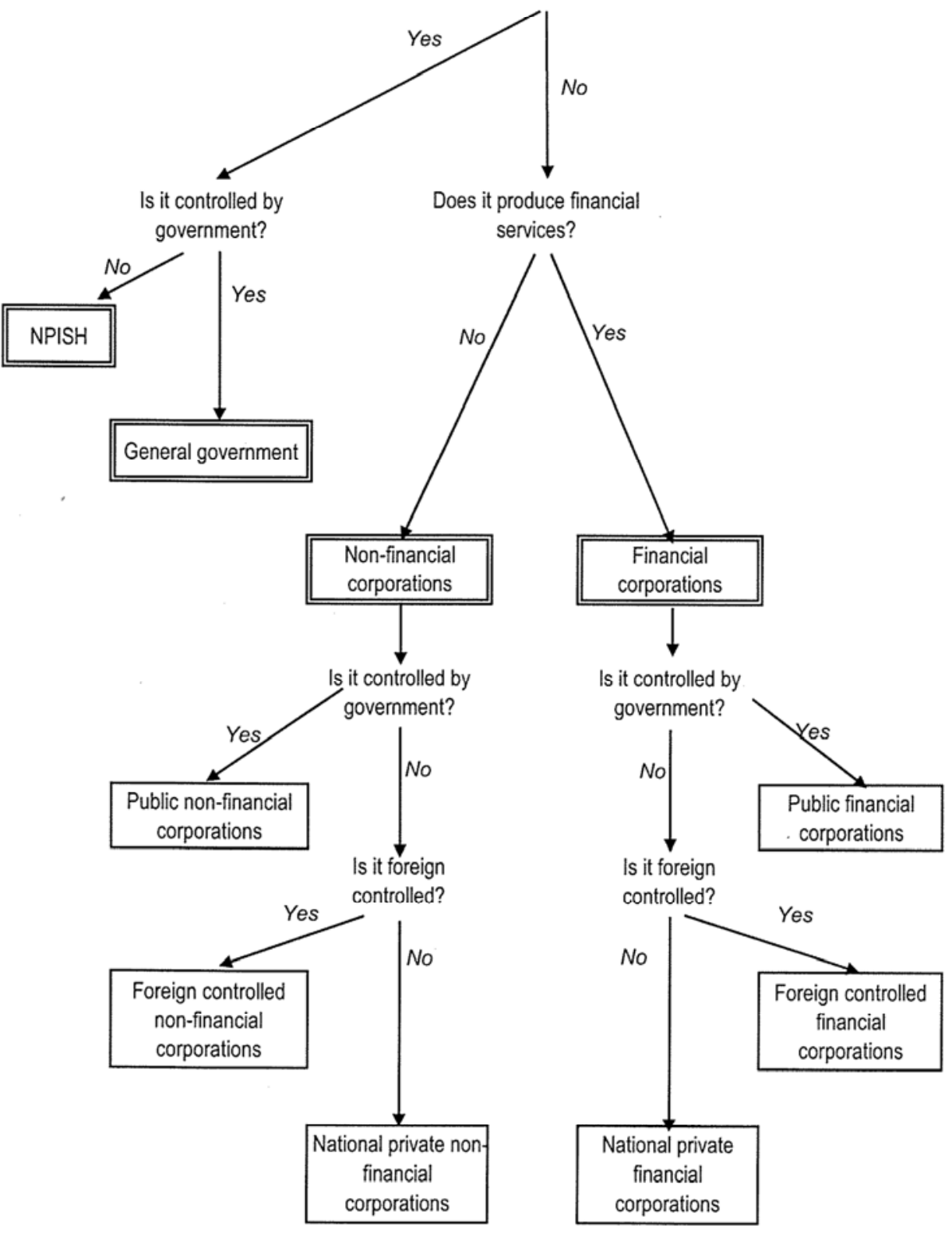

Source: SNA 1993. 


\section{REFERENCES QUOTED IN THE APPENDIX}

Bond, C., T. Martin, S. Hume McIntosh, and C. Ian Mead (2007), "Integrated Macroeconomic Accounts for the United States", Bureau of Economic Analysis, Survey of Current Business, February, 14-31, www.bea.gov/scb/pdf/2007/02\%20February/0207_macro_accts.pdf.

Cecchetti, S., M. Mohanty, and F. Zampolli (2011), “The Real Effects of Debt”, BIS Working Papers No. 352 .

Central Statistical Office $(1987,1994)$. The CSO Blue Book of United Kingdom National Accounts.

Deutsche Bundesbank (1994), Ergebnisse der gesamtwirtschaftlichen - Finanzierungschaftlichen für Westdeutschland 1960 bis 1992, November.

Herve, K. et al. (2010), The OECD's New Global Model, OECD Economics Department Working Papers, No. 768.

Mink, R. (2006), "Classification and Terminology of Financial Assets and Liabilities in the Updated SNA", Paper presented at the fourth meeting of the Advisory Expert Group on National Accounts (AEG) at the European Central Bank in Frankfurt am Main, 30 January to 8 February 2006, http://unstats.un.org/unsd/nationalaccount/aeg/papers/m4liabilities.pdf.

System of National Accounts, 1993 and 2008. 
ECO/WKP(2013)69

\section{WORKING PAPERS}

The full series of Economics Department Working Papers can be consulted at www.oecd.org/eco/workingpapers/

1076. Policies to support sustainable long-term growth in New Zealand

(July 2013) by Calista Cheung

1075. Do structural policies affect macroeconomic stability?

(July 2013) by Volker Ziemann

1074. A simple fiscal stress testing model - case studies of Austrian, Czech and German economies (July 2013) by Ondra Kamenik, Zdenek Tuma, David Vavra and Zuzana Smidova

1073. Road connectivity and the border effect: evidence from Europe

(July 2013) by Henrik Braconier and Mauro Pisu

1072. Fiscal consolidation across government levels. Part 3: Intergovernmental grants, pro- or counter-cyclical?

(July 2013) by Hansjörg Blöchliger and Balázs Égert

1071. Fiscal consolidation across government levels. Part 2: Fiscal rules for sub-central governments, update of the institutional indicator

(July 2013) by Kaja Fredriksen

1070. Fiscal consolidation across government levels. Part 1: How much, what policies?

(July 2013) by Hansjörg Blöchliger

1069. Restructuring the electricity sector and promoting green growth in Japan

(June 2013) by Randall S. Jones and Myungkyoo Kim

1068. Labour market policies to promote growth and social cohesion in Korea

(June 2013) by Randall S. Jones and Satoshi Urasawa

1067. Education reform in Korea

(June 2013) by Randall S. Jones

1066. Belgium: enhancing the cost efficiency and flexibility of the health sector to adjust to population ageing

(June 2013) by Stéphane Sorbe

1065. Italy and the euro area crisis: securing fiscal sustainability and financial stability

(June 2013) by Oliver Denk

1064. Policy implementation in Italy: legislation, public administration and the rule of law

(June 2013) by Paul O’Brien

1063. Greening growth in Luxembourg

(June 2013) by Nicola Brandt

Vers une croissance plus verte en Luxembourg

(juin 2013) par Nicola Brandt 
1062. The post-crisis narrowing of international imbalances - cyclical or durable?

(June 2013) by Patrice Ollivaud and Cyrille Schwellnus

1061. Restructuring welfare spending in Slovenia

(June 2013) by Rafał Kierzenkowski

1060. The economics of civil justice: new cross-country data and empirics

by G. Palumbo; G. Giupponi; L. Nunziata and J. Mora-Sanguinetti (forthcoming)

1059. Banks' restructuring and smooth deleveraging of the private sector in Slovenia (June 2013) by Olena Havrylchyk

1058. Assessing the efficiency of welfare spending in Slovenia with data envelopment analysis (June 2013) by Matevz Hribernik and Rafał Kierzenkowski

1057. Policy determinants of school outcomes under model uncertainty: evidence from South Africa (June 2013) by Thomas Laurent, Fabrice Murtin, Geoff Barnard, Dean Janse van Rensburg, Vijay Reddy, George Frempong and Lolita Winnaar

1056. Improving education quality in South Africa (June 2013) by Fabrice Murtin

1055. The 90\% public debt threshold: the rise and fall of a stylised fact (June 2013) by Balázs Égert

1054. Challenges to sustain Poland's growth model (June 2013) by Balázs Égert and Rafał Kierzenkowski

1053. Reforming agriculture and promoting Japan's integration in the world economy (May 2013) by Randall S. Jones and Shingo Kimura

1052. Inequality and poverty in the United States: public policies for inclusive growth (May 2013) by Oliver Denk, Robert Hagemann, Patrick Lenain and Valentin Somma

1051. Fiscal federalism and its impact on economic activity, public investment and the performance of educational systems

(May 2013) by Hansjörg Blöchliger, Balázs Égert and Kaja Fredriksen

1050. Restoring Japan's fiscal sustainability

(May 2013) by Randall S. Jones and Satoshi Urasawa

1049. Measuring total factor productivity at the firm level using OECD-ORBIS

(May 2013) by Peter Gal

1048. A projection method for public health and long-term care expenditures (June 2013) by Christine de la Maisonneuve and Joaquim Oliveira Martins

1047. R\&D, patenting and growth: the role of public policy

(May 2013) by Ben Westmore 